Fall 1930

\title{
1930 Cedrus Yearbook
}

\section{Cedarville College}

Follow this and additional works at: https://digitalcommons.cedarville.edu/yearbooks

Part of the Higher Education Commons, Organizational Communication Commons, and the Public Relations and Advertising Commons

\section{Recommended Citation}

Cedarville College, "1930 Cedrus Yearbook" (1930). Yearbooks. 76.

https://digitalcommons.cedarville.edu/yearbooks/76

This Book is brought to you for free and open access by DigitalCommons@Cedarville, a service of the Centennial Library. It has been accepted for inclusion in Yearbooks by an authorized administrator of DigitalCommons@Cedarville. For more information, please contact digitalcommons@cedarville.edu. 


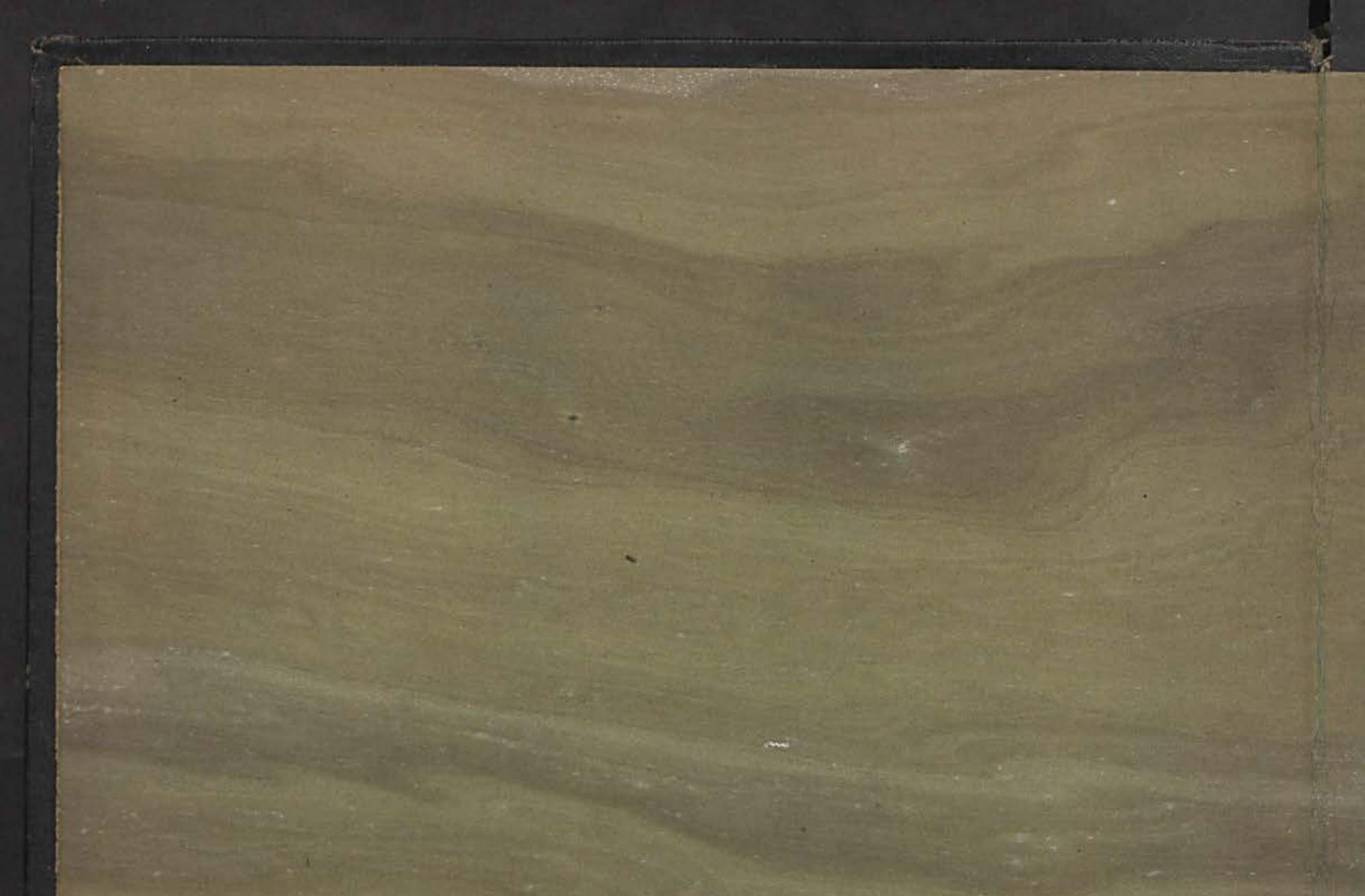




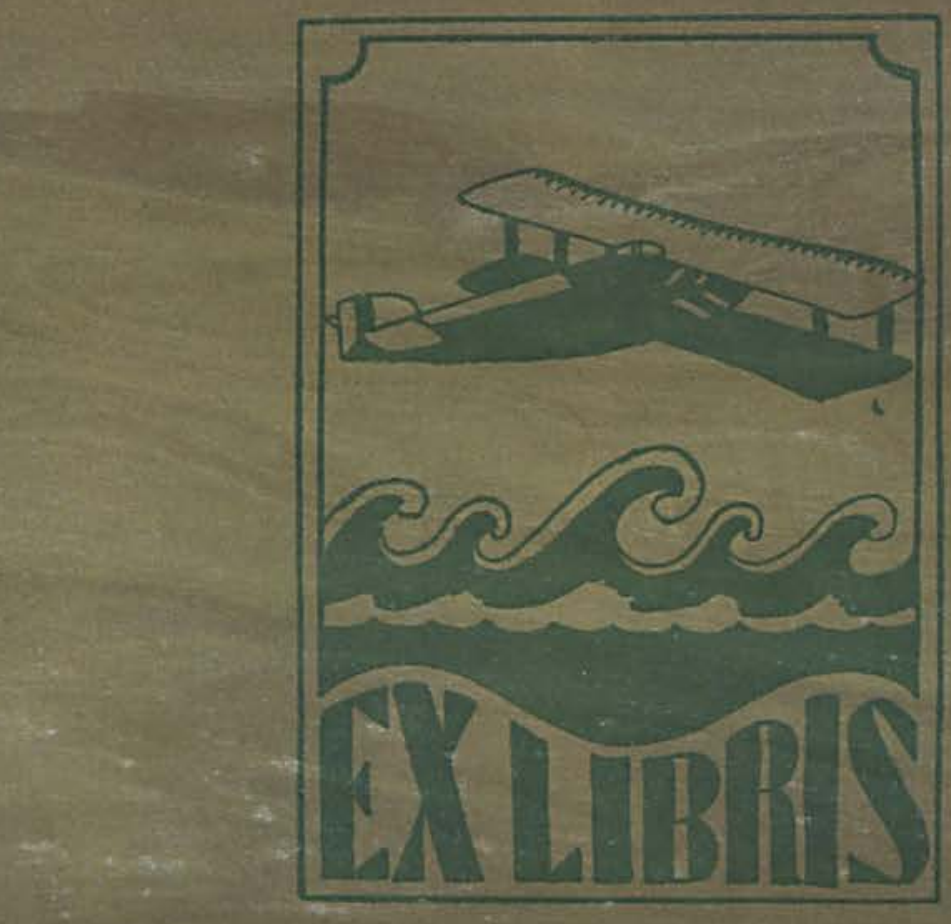




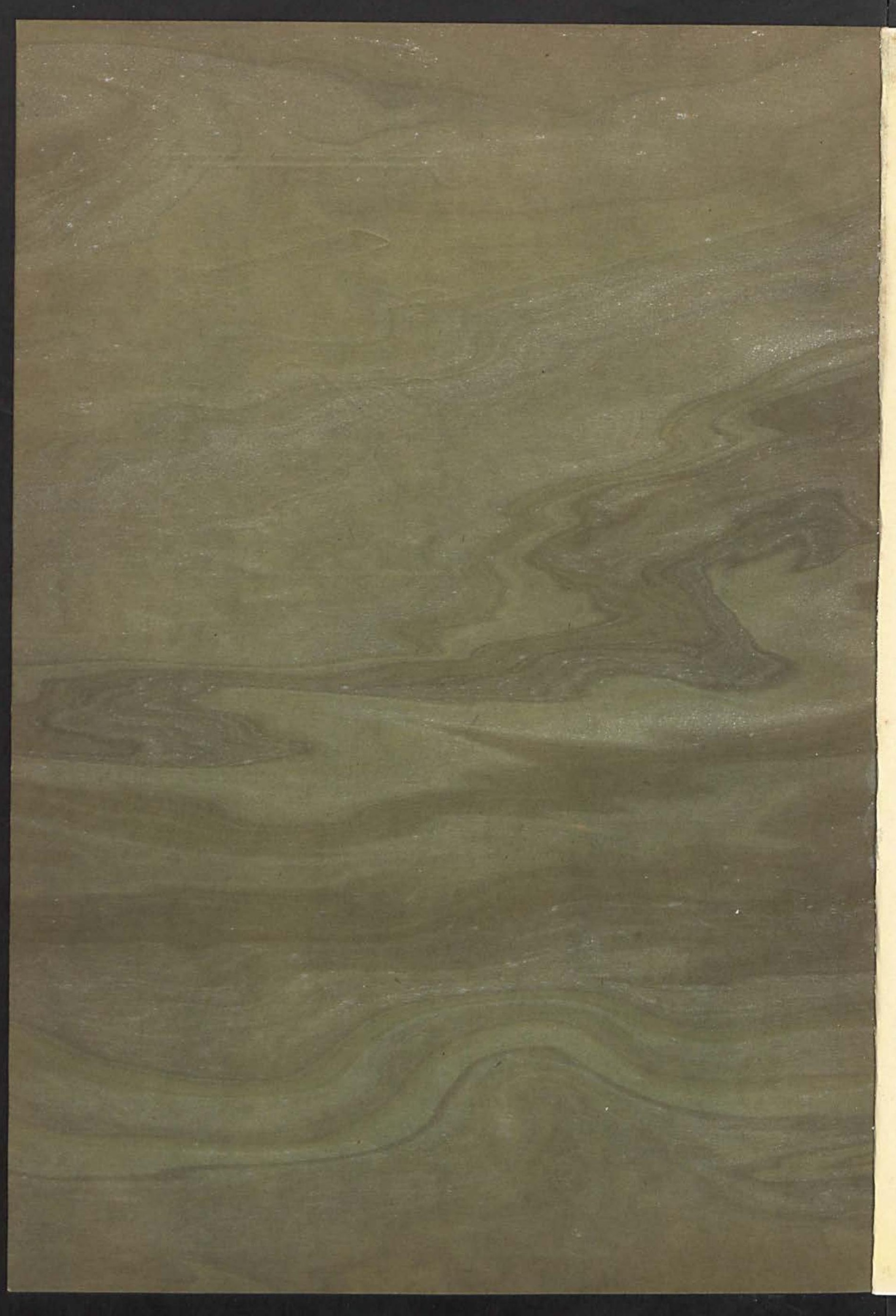




\title{
7\%. Poners.
}

\section{The Cedrus}

For The Students

of

Cedarville College

\author{
Compiled and Edited \\ by the \\ CEDRUS STAFF
}

Elected by the Student Body 


\section{The Open Book}

None can sing of life that it has not sung.

Or of death that it has not told:

For the very things that are new to us

To the open book are old.

But the glory of it and of all its joy

Exists in this fact. For look!

Whereas all things in it to it are old

Age comes not to the open book.

I sing of a thing that lives with the world,-

Lives as long and is just as new.

For the next race of men will learn those things

That the last race taught to you.

But what would be old to you and the book,

And the world, to them is new.

And they love the world, and the sun, and the moon,

For they're new, - and the book is, too.

So pray let me sing of the trusted tome

Which has brought us through to the dawn,

Which along with the world, the stars, and home

Will exist when we pass on,

And will shed their sweet light forever new

Like the sunlight, in each nook.

I sing not of binding, or print, or gilt;

I sing of the open book!

F. M. 


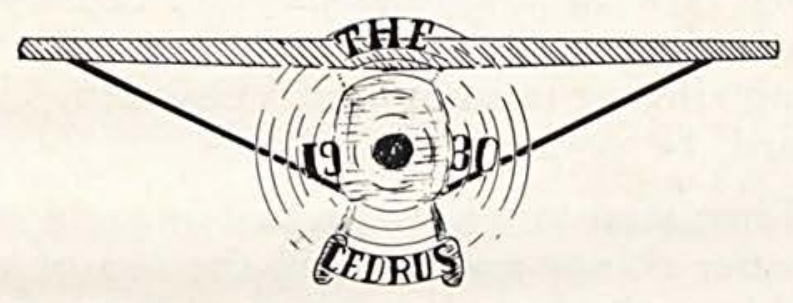




\section{Foreword}

W OULDN'T it be wonderful to live forever as a happy student at dear old C. C. But such is your fate, just as you begin to learn how to go to school you must leave with those words of your Alma Mater song ringing in your ears, "Onward, Upward, be your motto still."

Then after you have pressed on, achieved greater things and reached the top of the ladder; when you are sitting at home by a cozy fireside after the day's work is done; it is then that the staff of this book hopes that it will bring you far more enjoyment than now. 


\section{Dedication}

To those upon whose past and present achievements the future greatness of Cedarville College will be built--This volume of "The Cedrus" is respectfully dedicated. 
Contents

I Scenes

II Faculty

III Seniors

IV Juniors

V Sophomores

VI Freshmen

VII Athletics

VIII Organizations

IX Activities 

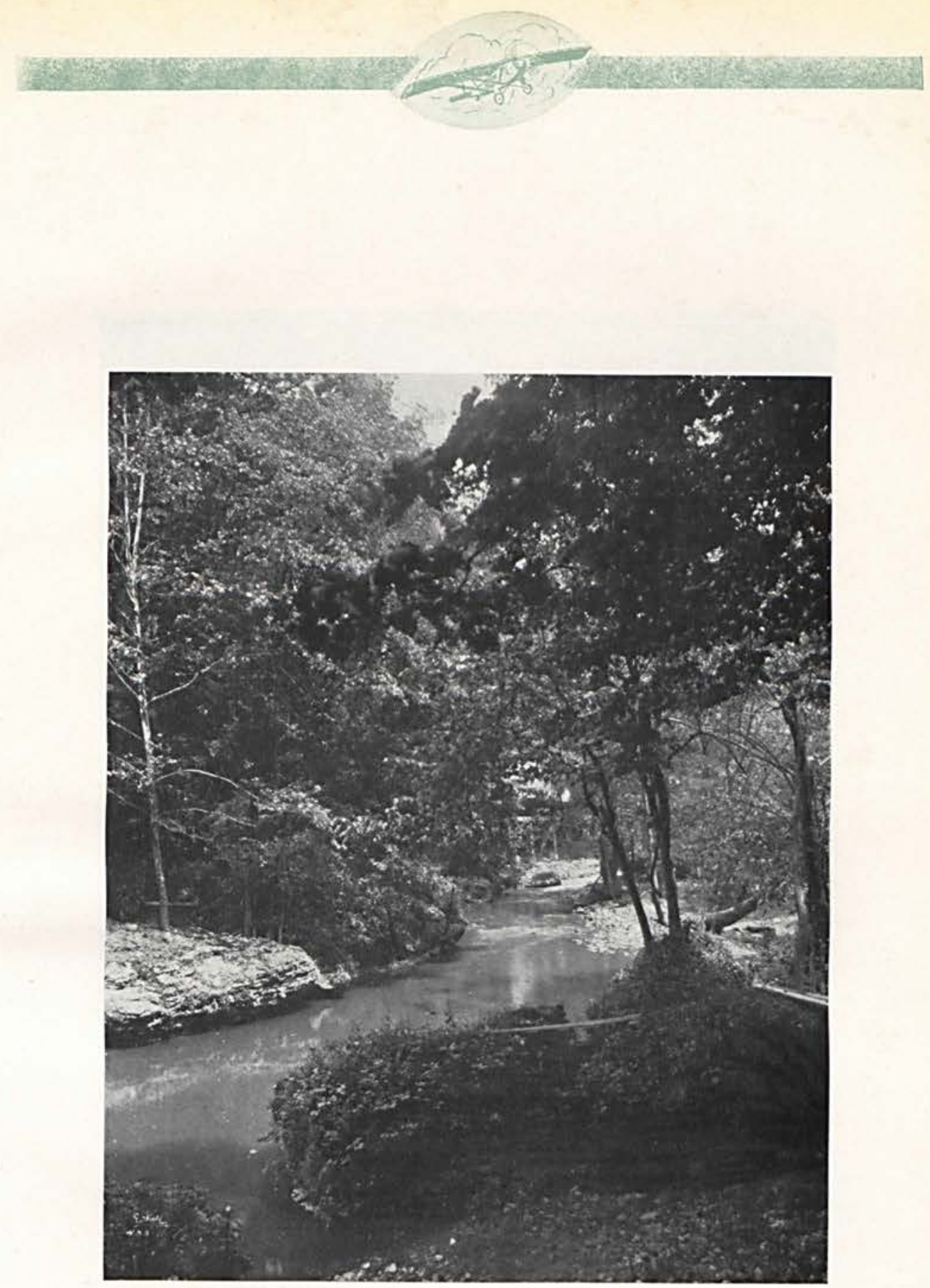

"We shall forget — but never this."
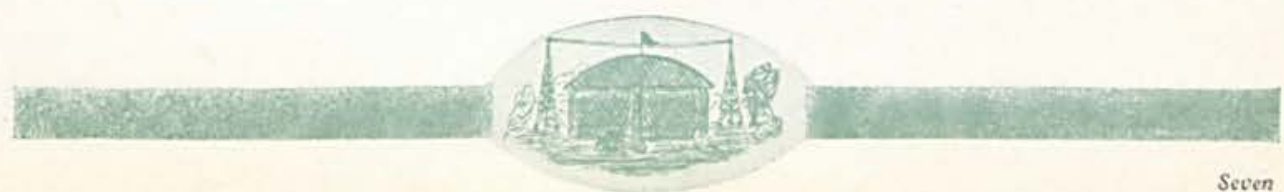


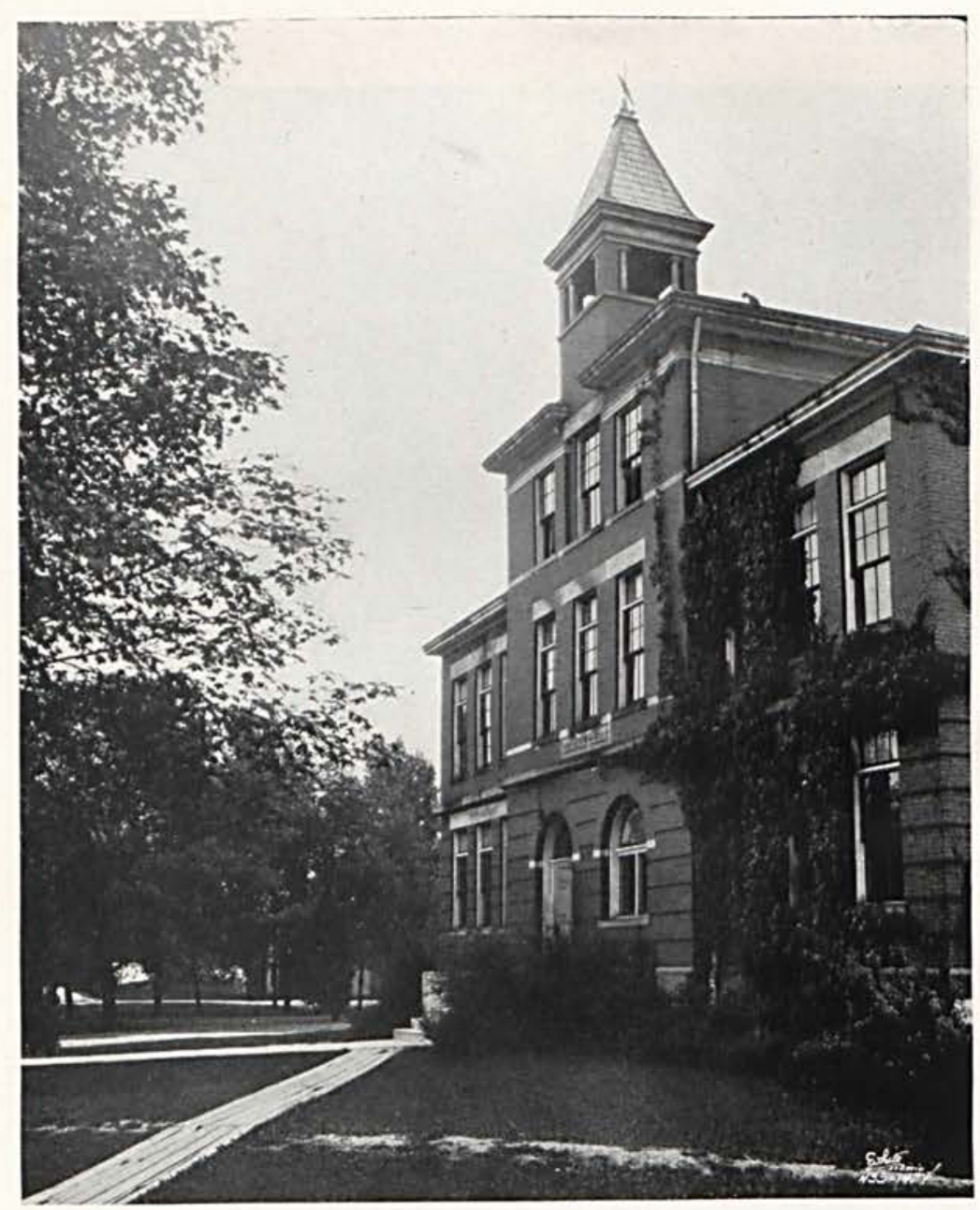

Old Main

"Perchance in after years when friends shall speak Of some celebrity, or of a friend more lowly,

'T will be thy privilege to nod and say,

'I knew him there.'." 


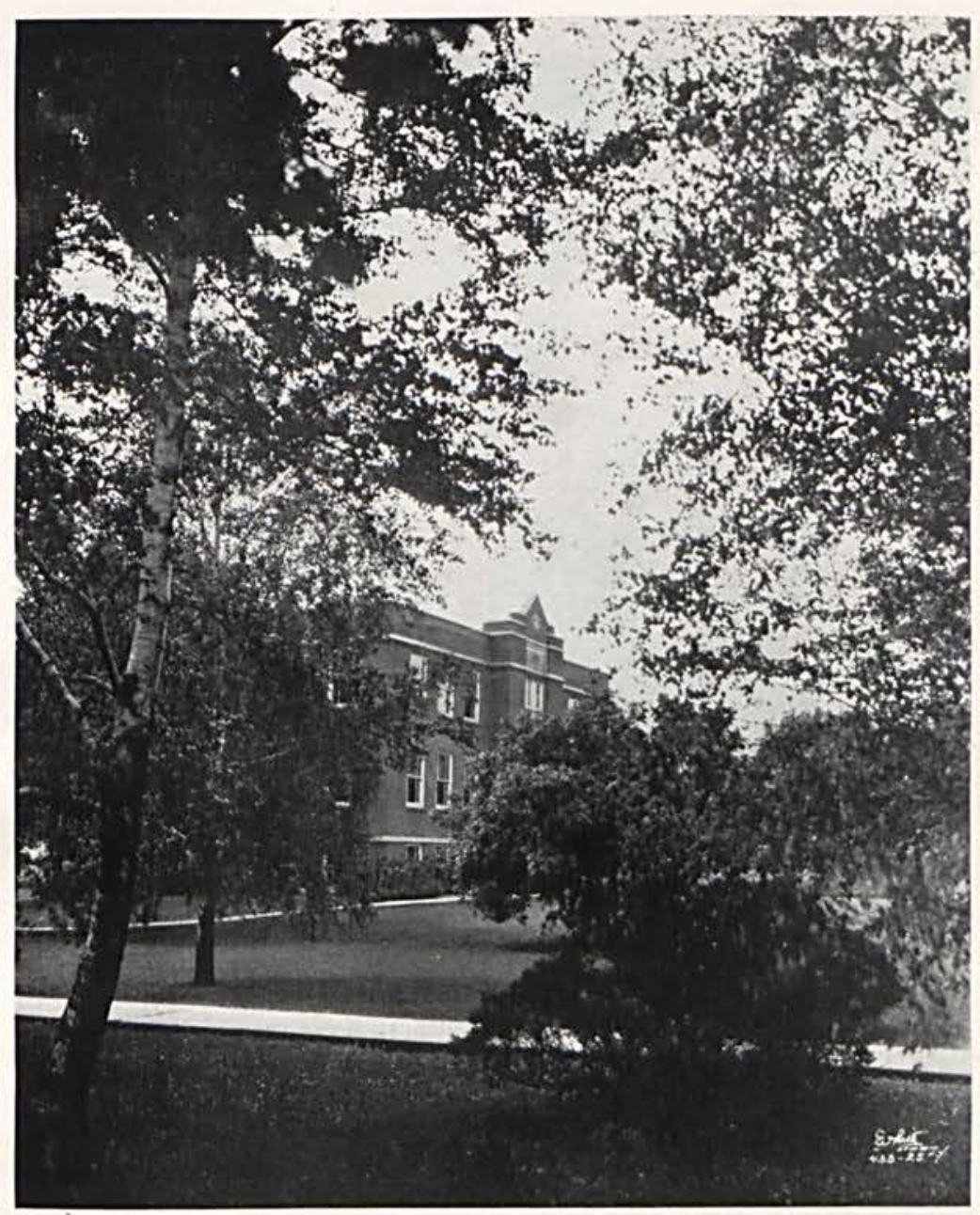

Science Hall

"Sunlight sifting lacelike thru the leaves

Shadows the campus; when the day is done

We will forget that there were shadows

Remembering the sun." 

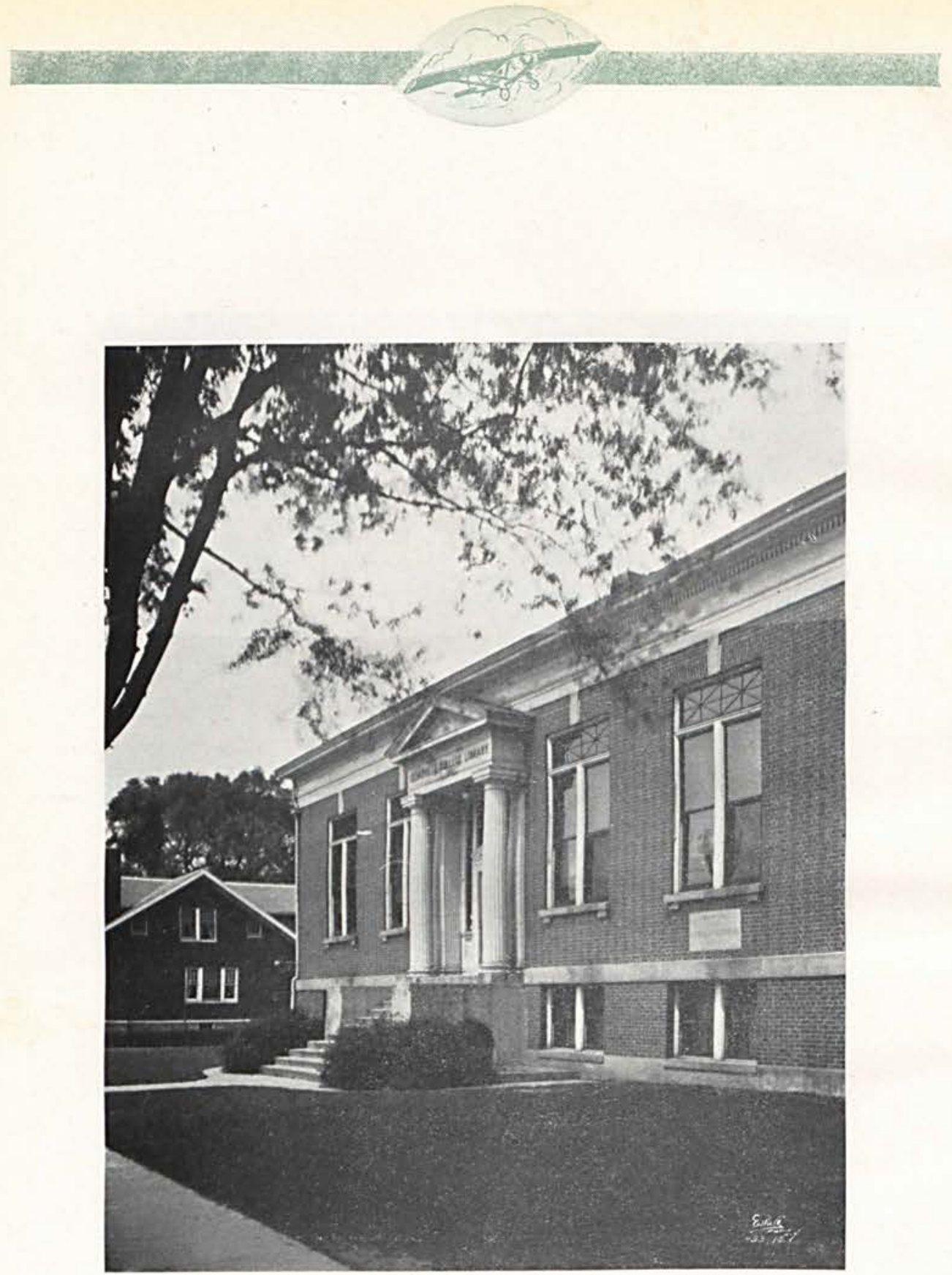

Library

"Where should I find such friends elsewhere Who so conveniently would suit my mood, As in this veritable home of peace

Where naught is rudely silenced, yet all's still?"

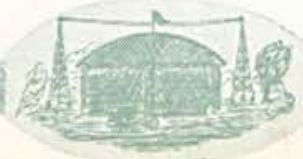





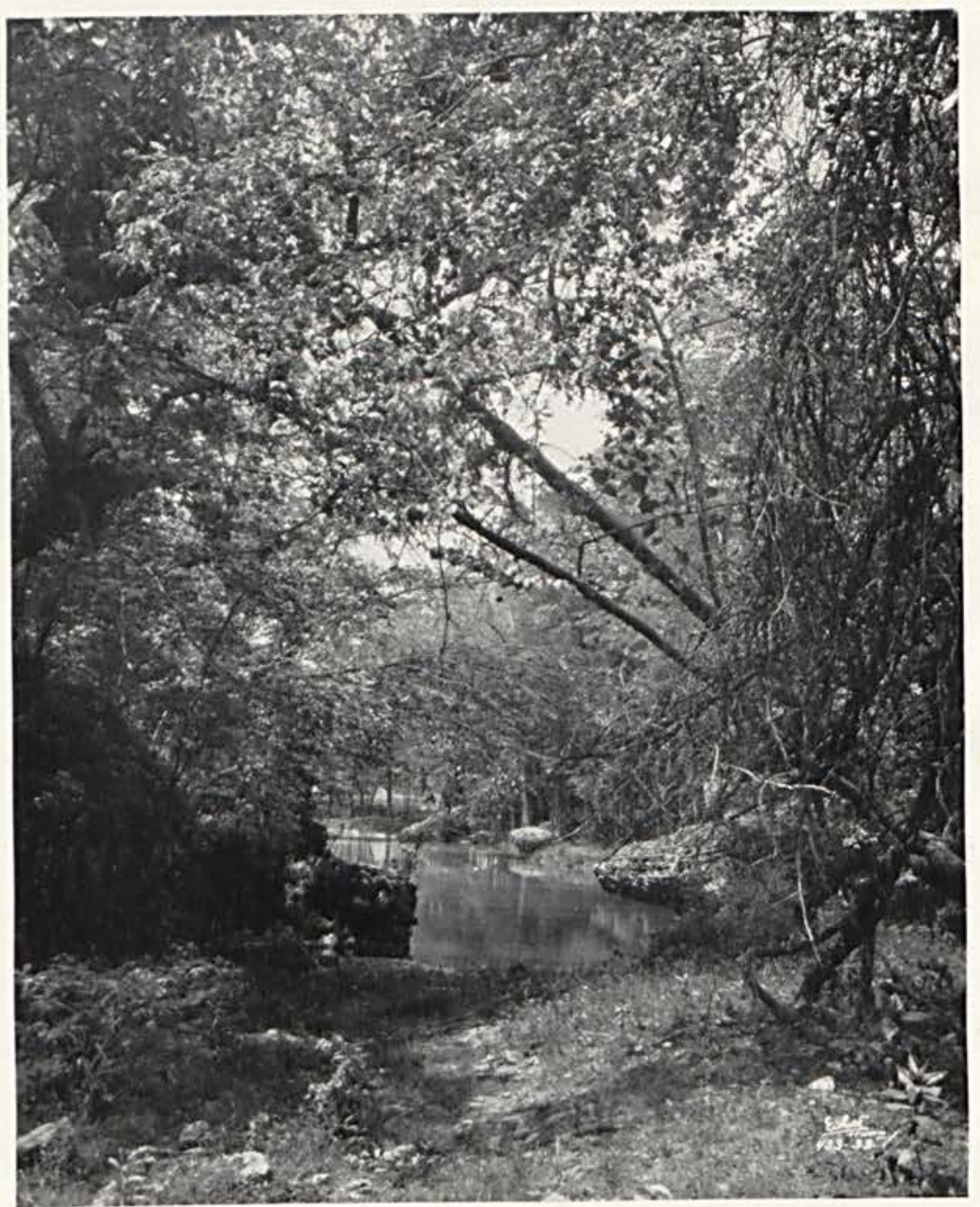

"Where men as yet had made no walk or lawn From where the Indian beauty seemed withdrawn Scarcely as yet, an Indian solitude Seemed on the glittering waters."

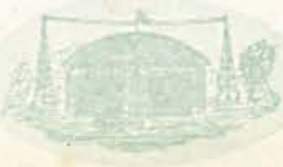




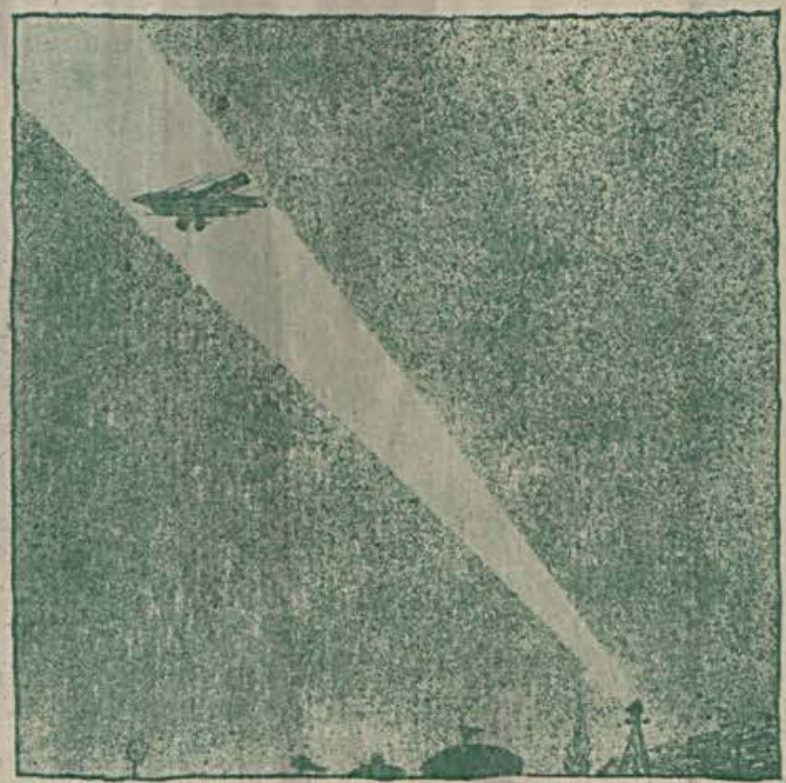

$\mathfrak{J}$ aculty 



\section{Faculty}

Oh, the Faculty, they all weat specs

That is, all'cept a few.

And what they don't know is supplied

By friends like me and you.

Hey there!

Hain't thet so? 
McChesney sat on one end of a log

And I sat on the other.

McChesney came as a pedagogue

And taught as an elder brother.

I don't care what McChesney taught-

Though he knew the things that I judged he ought-

For I thought, thought I,

All through lecture time and quizz,

The kind of a man I mean to be

Is the kind of a man McChesney is!

Not all the books on all the shelves

But what the teachers are themselves.

For education is making men;

So is it now, so was it when

McChesney sat on one end of a log

And I sat on the other.

Orland M. Ritchie, '16. 


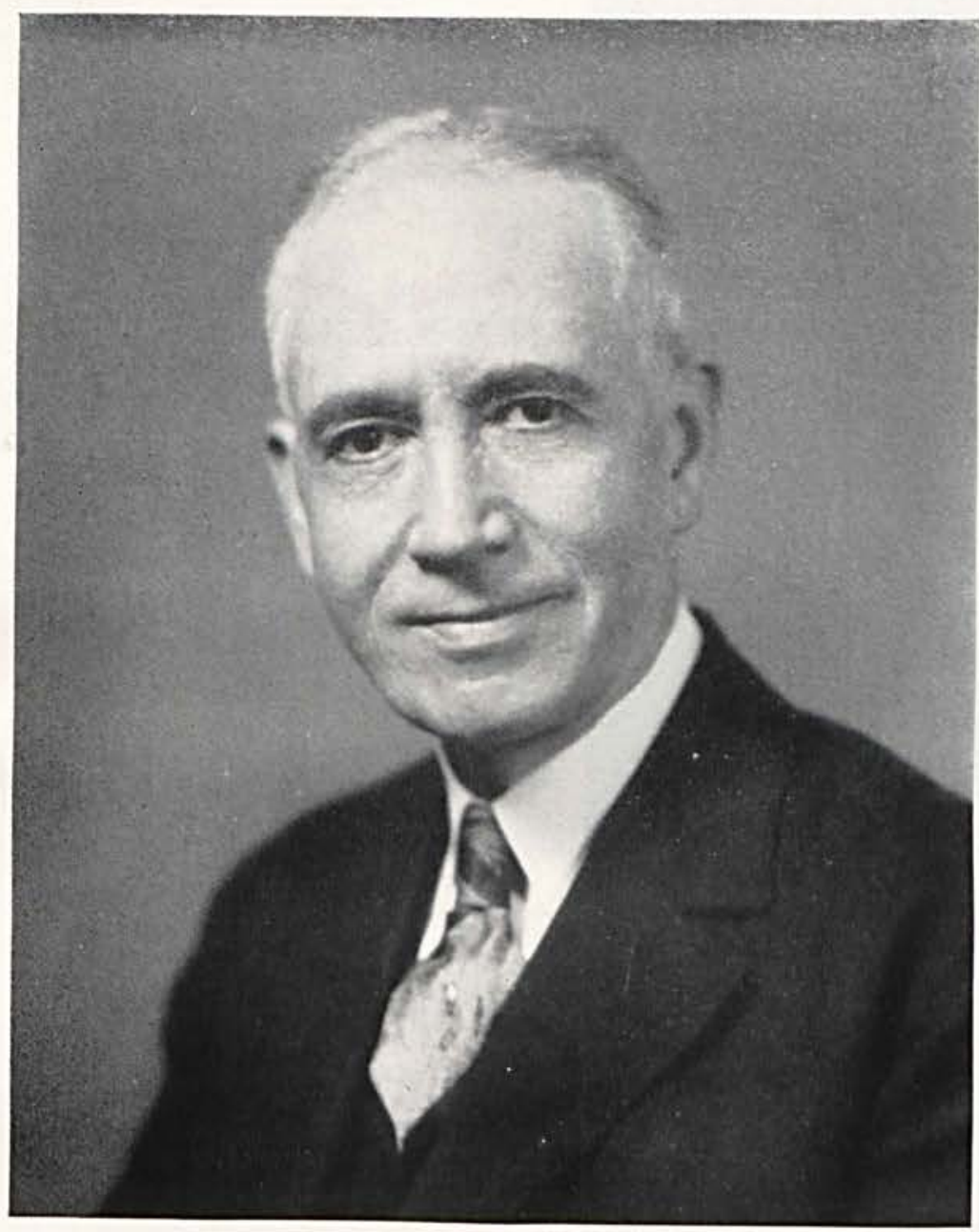

WILBERT RENWICK McCHESNEY, Ph. D., D. D. President of Cedarville College
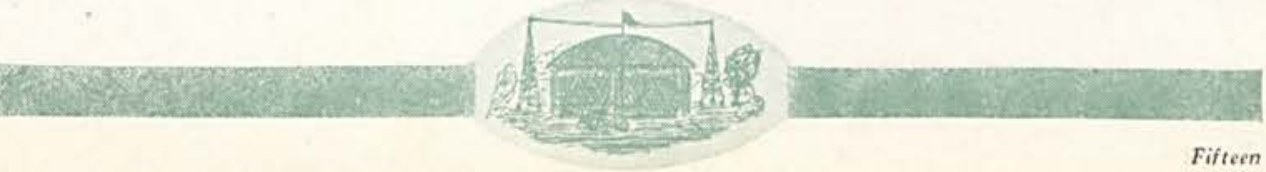


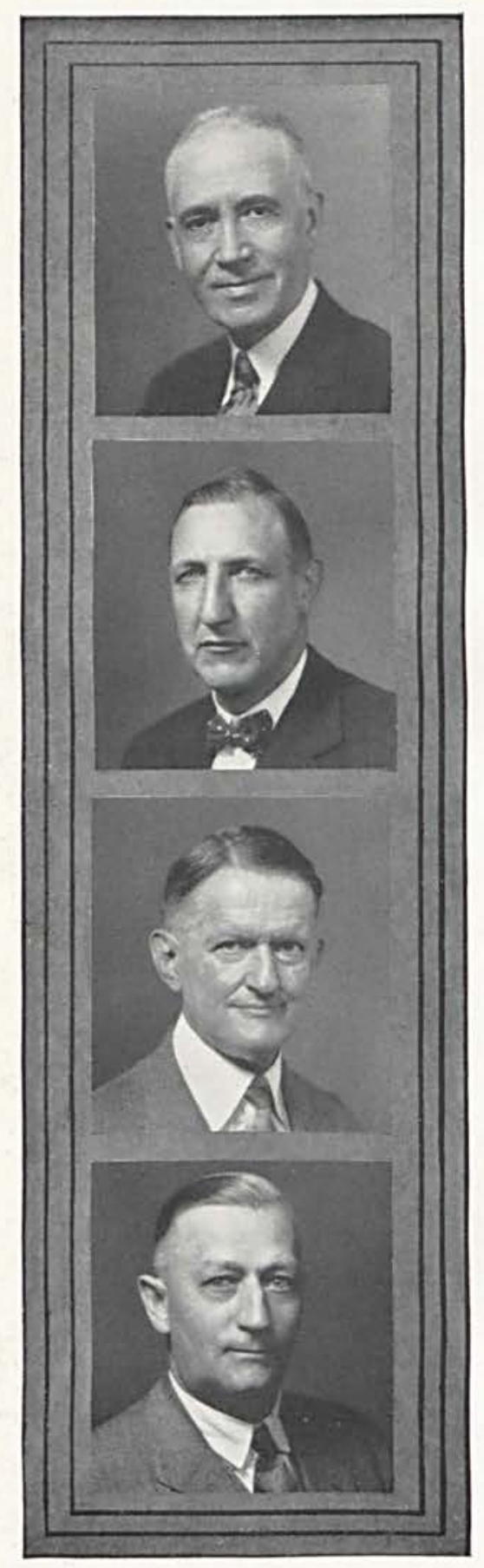

\section{W. R. McCHESNEY}

\section{President}

Peter Gibson Professor of Philosophy and Greek A. B. Franklin College

A. M. Franklin College

$\mathrm{Ph}$. D. Franklin College

D. D. Tarkio College

\section{FRANK A. JURKAT}

\section{Treasurer}

Professor of Languages and History
A. B. Franklin College
A. M. Franklin College
L.L. D. Franklin C
A. M. Wittenberg

\section{J. A. DICKINSON}

\section{Vice-President}

A. B. Wooster College

A. M. Wooster College

C. W. STEELE

\section{Dean of Men}

Professor of Social Sciences and Bible A. B. Indiana State Normal

Chicago University 
R. M. BORST

Director of Physical Education Professor of Spanish

B. S. Wittenberg

\section{NORMA WOOD}

Professor of French and Spanish

A. B. Ohio State University A. M. Ohio State University

DOROTHY ANGEVINE

Professor of English and French

A. B. Denison University

A. M. Ohio State University

\section{O. W. KUEHRMANN}

Professor of Science

B. S. Purdue University Butler College

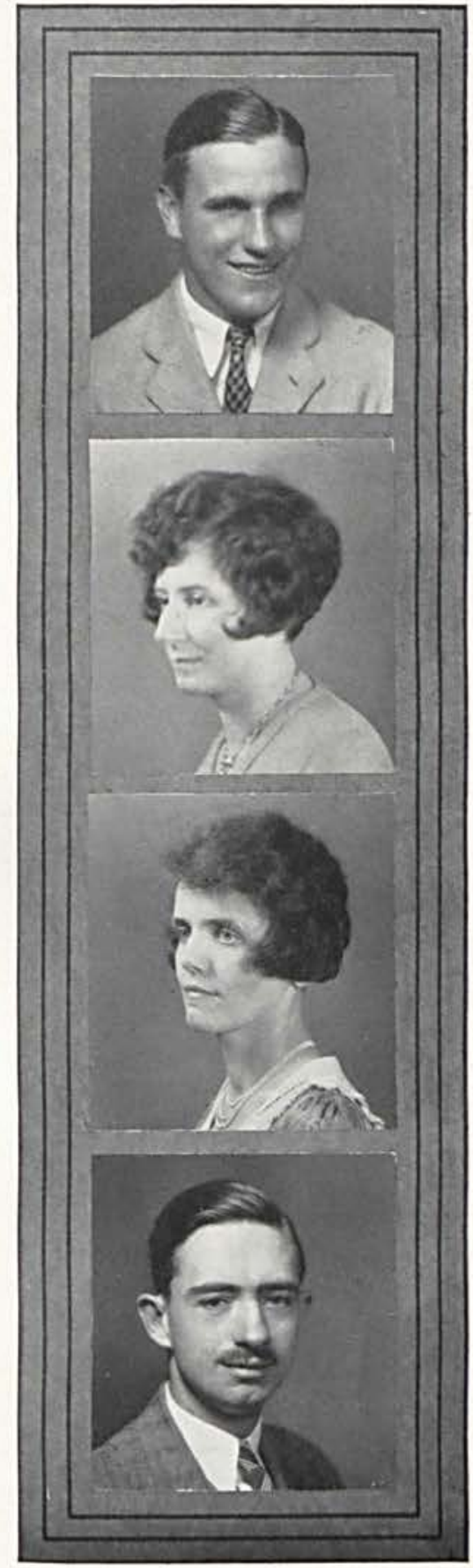



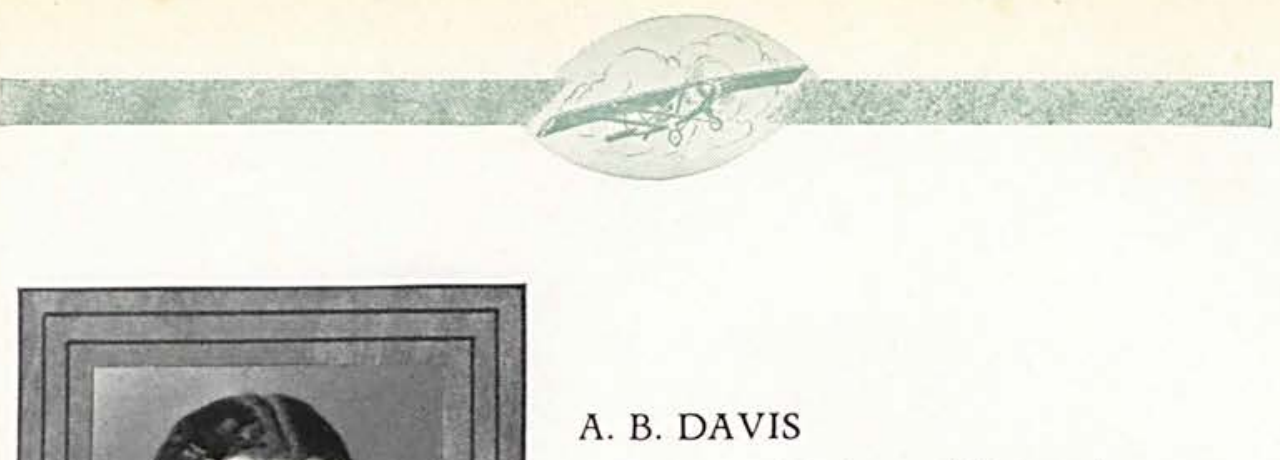

Registrar and Professor of Mathematics

B. S. Education, Findlay College

A. B. Ohio State University

A. M. Ohio State University

\section{JANICE SHEDD}

Professor of Debate and History

B. S. Education, Ohio State University

A. B. Ohio State University

A. M. Ohio State University

\section{A. J. HOSTETLER}

Head of Department of Education B. S. Ohio State University

\section{ABIGALL BRISTOW}

Director of Teacher Training

A. B. Wittenberg College

A. M. Columbia University

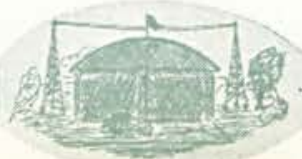





\section{The Faculty}

It gives us great pleasure to dedicate this page to our faculty, thus showing in some measure the gratitude which we feel for them for all that they have so willingly done for us.

Dr. McChesney, President of Cedarville College, has been on its staff since 1894. Each year through his untiring efforts he becomes more of an inspiration to us to work harder in the perpetuation of our beloved Alma Mater.

Dr. Jurkat, Treasurer and Professor of German and History, came to C. C. in 1895. A real student and lover of knowledge he sets an example which most of us might well follow during our College Course.

Dean Steele came in 1927 as Professor of Bible and Sociology. This year, due to his faithful service, he has been appointed Dean of Men.

Dean Angevine, Professor of English and Latin, came to C. C. in 1929. Due to her tact and humor she is very popular with the student body. As Dean of Women she has been very successful.

Professor Kuehrman, Head of the Department of Science, has accomplished much in building up that Department. Although he has only been with us two years we feel that he is an integral part of the faculty.

Professor Davis, Registrar and Professor of Mathematics, is a diligent worker in behalf of the future success of C. C.

Mrs. Shedd, Professor of Psychology and History, came in 1929 to C. C. She is Assistant Registrar and in that capacity has much contact with the students.

Miss Wood, Professor of Romance Languages, is one of our most conscientious instructors. She has a real love for her work which cannot help but win our respect.

Miss Berkley, Head of the Department of Music since 1928, has installed a Men's and Women's Glee Club which are very popular with the student body as well as a source of pleasure to the community.

Mrs. Corry, Assistant in the Department of Music, has been a willing helper in the Women's Glee Club as well as in every other activity in the community.

Coach Borst, Head of the Athletic Department and Professor of Spanish, shows us the attitude of true sportsmanship which is so necessary in all life's activities.

Professor Hostetler, Director of Education, has a wide field of experience which he is ever ready to share with the students of C. C.

Miss Bristow, Professor of Education and Teacher Training, has a lasting influence on every prospective teacher graduating from C. C.

Miss Parry, Professor of Education, is an industrious worker for the betterment of the students of C. C.

Mrs. Borst, Professor of Education, as manager of Cedar-Day, always aids in making our memories of Commencement Week more pleasant.

This year has marked greater success for Cedarville College than has any in the past. Ever on ward is our goal and we are sure that all this Senior Class will join in the advance toward this goal with our Faculty.

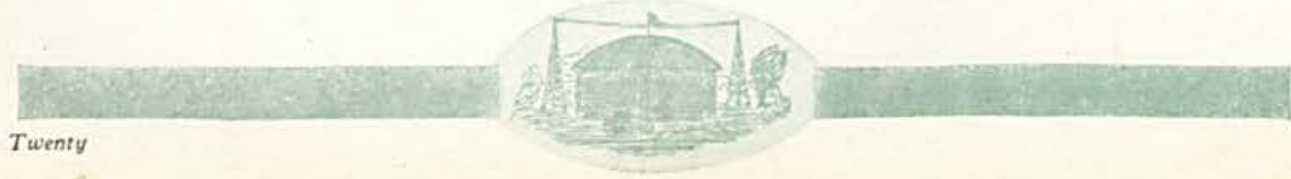




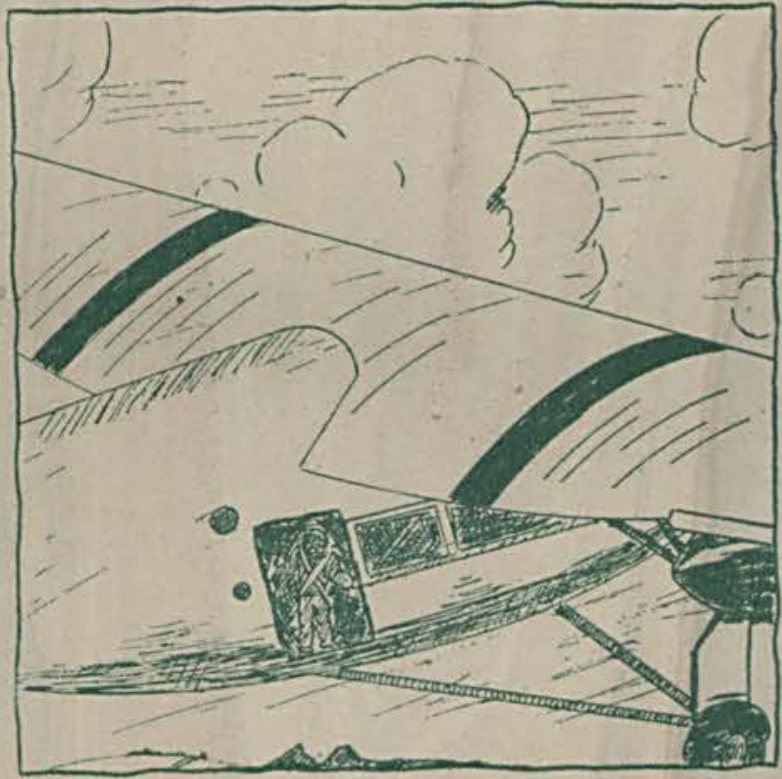

\section{Seniors}




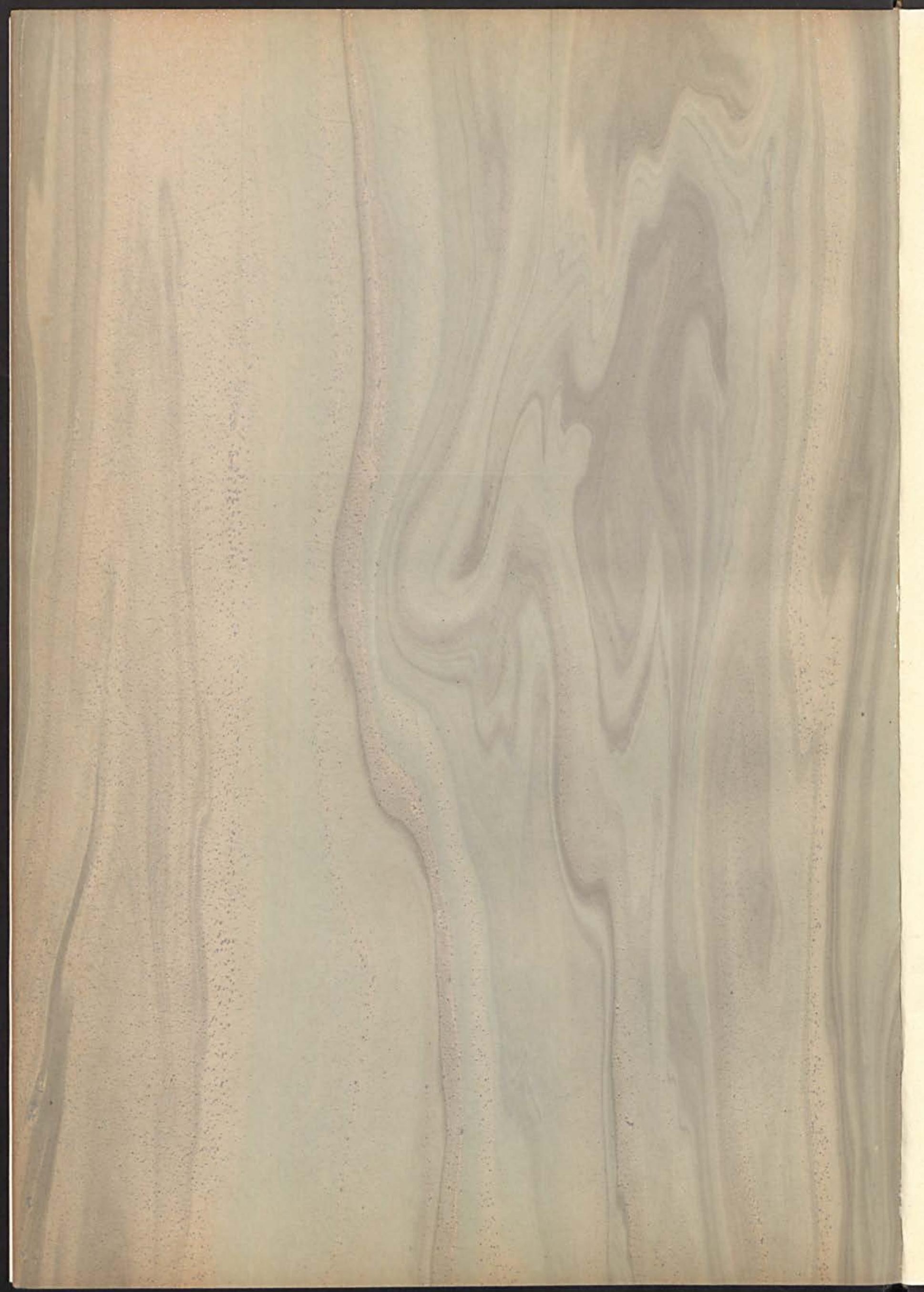




\section{Seniors}

Oh, the Seniors are so dignified

If they would bend they'd crack.

But that's in public-not at home.

For there they get set back

Hard! Noble ones!

You'te not the only rusty tin cans in the dump. 


\section{The Seniors Bid Farewell}

Friends must part, alas forever Tho' I wish it were not so;

For its hard to now be passing, It is hard for us to go.

Silently, with teardrops flowing

We must bid farewell to you,

We as students in this college,

Greater friendship could not know.

But four years have passed so quickly

And we have to journey on;

Yet we ask you most sincerely

Not to mourn our passing on.

We have lived these years to-gether And have learned to love you too,

But now all our ties are severed And with sadness we must go.

As we go we all would cherish Just one parting word from you,

That may help us to remember As in life we're passing thru.

So we say farewell, Oh College, But excuse us if we cry;

We have spent these years to-gether And its hard to say goodbye.

George W. Davis, '30. 


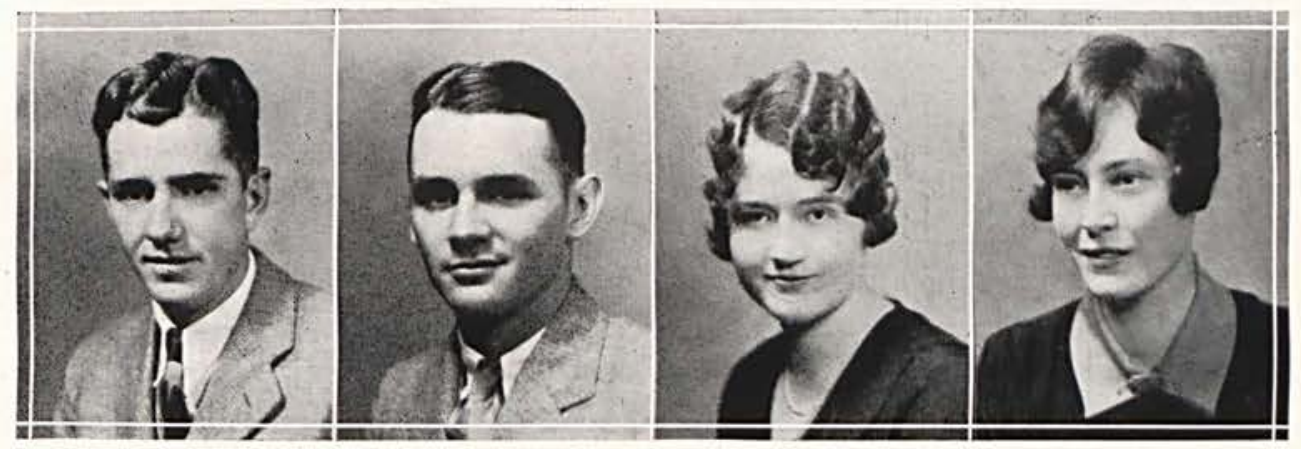

\section{Senior Class}

Dallas Marshall

President

Blair Brasel

Mary Ruth Wham

Lucile Tanner

Vice President Secretary

NO this is college. When we came to college in September 1926, we were very curious. (Freshmen are, you know). We paid strict attention to every announcement. (Freshmen do). We attended classes regularly and punctually. (Freshmen are guilty sometimes). And last of all we STUDIED. (Freshmen do that, too). Our motto was "Nil sine magno vita labore dedict mortalilus." (Life gives nothing to mortals without much labor).

But it paid. At the end of the year we were promoted to the rank of Sophomores. No terrible danger assailed us this year, such as haircuts, long rides, and long walks, although there were some upper classmen who felt that we had not yet received our share of such treatment.

Then our Junior year came sailing around with several new ones on the crew of teachers. We soon became acquainted and liked them fine. The great events of the year were connected with the play "Billy" which was a big hit and the banquet. Perhaps we shouldn't say much about that since we gave it.

Now, we are Seniors. It doesn't seem so long since we started, at first though, but-consider all the things that have happened-it has been four years all right. There are several great occasions ahead of us, but there is one of prime importance.

"To graduate, or not to graduate:

That is the question." (Before the class of 1930)

(This will be according to the professors, not Shakespeare)

In closing we could say that we have the best class that has ever graduated, but that is rather common, so we just want to say that we give our very best wishes to our Alma Mater.

M. J. A.
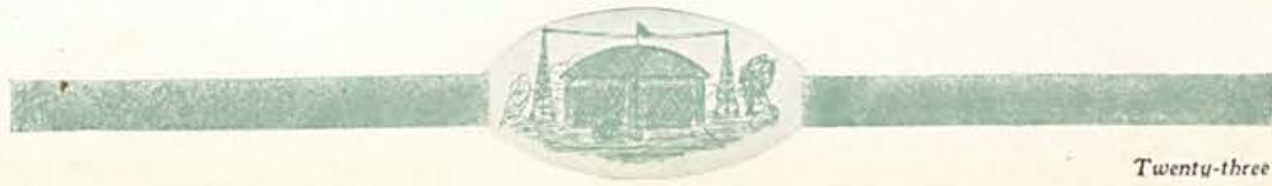

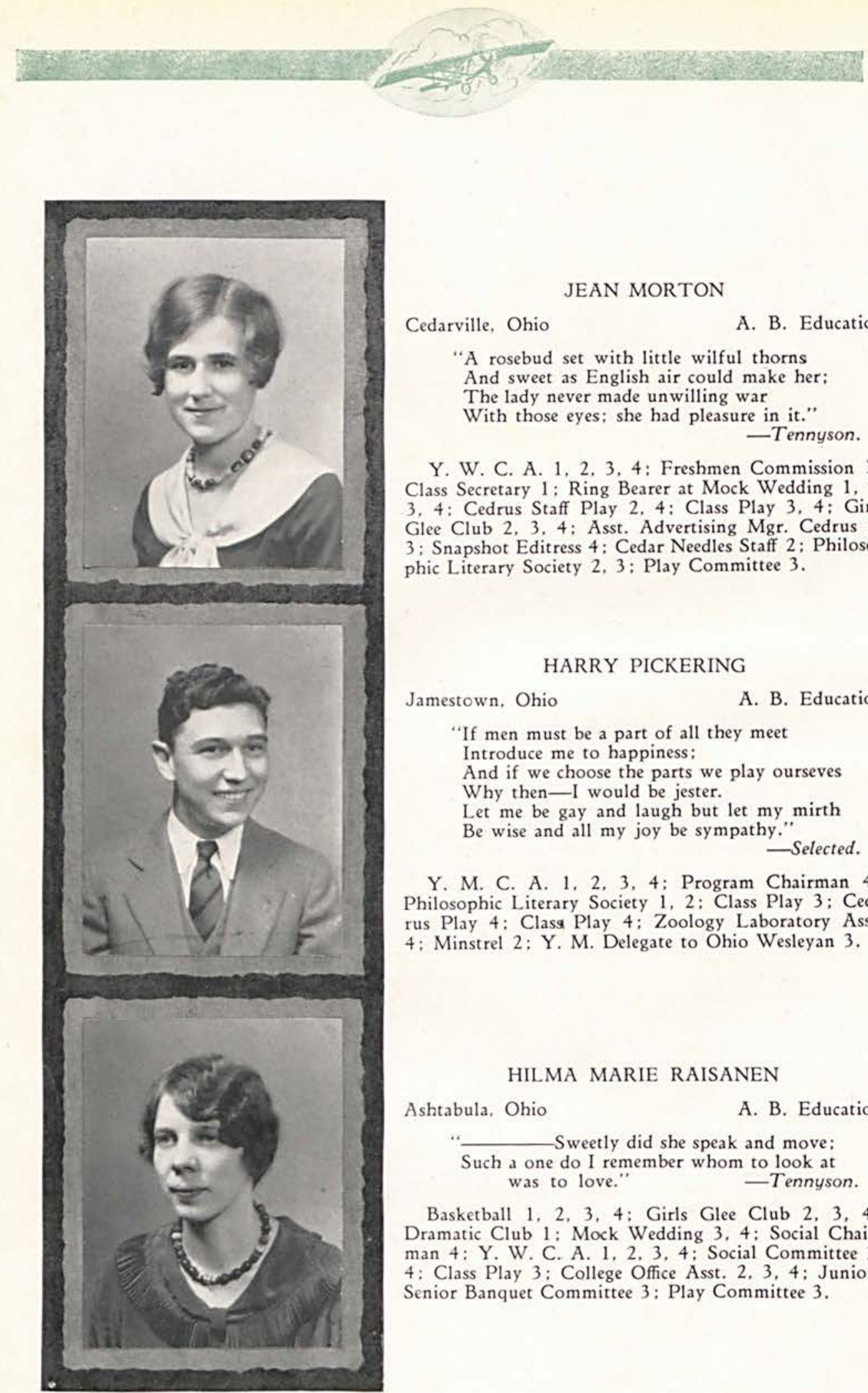

\section{JEAN MORTON}

Cedarville, Ohio

A. B. Education

"A rosebud set with little wilful thorns

And sweet as English air could make her:

The lady never made unwilling war

With those eyes; she had pleasure in it."

-Tennyson.

Y. W. C. A. 1, 2, 3, 4: Freshmen Commission 1: Class Secretary 1; Ring Bearer at Mock Wedding 1, 2 3, 4: Cedrus Staff Play 2, 4: Class Play 3, 4: Girls Glee Club 2, 3, 4: Asst. Advertising Mgr. Cedrus 2. 3: Snapshot Editress 4: Cedar Needles Staff 2; Philosophic Literary Society 2, 3; Play Committee 3.

\section{HARRY PICKERING}

Jamestown, Ohio

A. B. Education

"If men must be a part of all they meet Introduce me to happiness:

And if we choose the parts we play ourseves Why then-I would be jester.

Let me be gay and laugh but let my mirth $\mathrm{Be}$ wise and all my joy be sympathy."

Selected.

Y. M. C. A. 1, 2, 3, 4; Program Chairman 4: Philosophic Literary Society 1, 2: Class Play 3: Cedrus Play 4: Class Play 4; Zoology Laboratory Asst. 4: Minstrel 2: Y. M. Delegate to Ohio Wesleyan 3.

\section{HILMA MARIE RAISANEN}

Ashtabula, Ohio

A. B. Education

“- Sweetly did she speak and move;

Such a one do I remember whom to look at

$$
\text { was to love." -Tennyson. }
$$

Basketball 1, 2, 3, 4: Girls Glee Club 2, 3, 4; Dramatic Club 1: Mock Wedding 3, 4: Social Chairman 4: Y. W. C. A. 1, 2, 3, 4: Social Committee 3, 4: Class Play 3: College Office Asst. 2, 3, 4: JuniorSenior Banquet Committee 3: Play Committee 3.

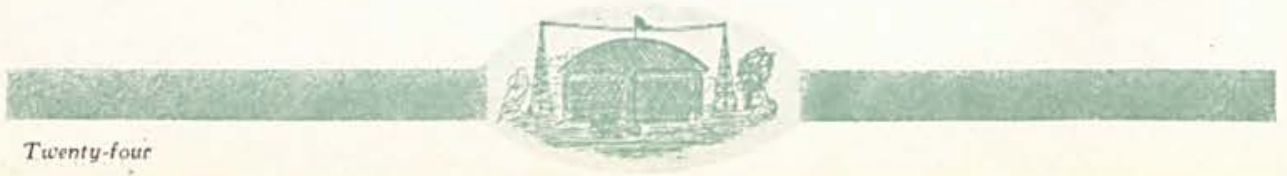




\section{FRANCES McCHESNEY}

Cedarville, Ohio

"Yet if we could scorn

Hate, and pride, and fear;

If we were things born

Not to shed a tear.

I know not how thy joy we ever should come near."

A. B. Education

Cedrus Staff 3, 4: Cedrus Play 4: Class Play 4: Y. W. C. A. 1, 2, 3, 4; Program Chairman 3: President 4: Philosophic Literary Society 1, 2: Girls Glee Club 1, 2, 3, 4: Cedarville College Crown Club 3; Delegate to Y. W. Conference at Denison 2, at Geneva 3: Delegate to Bible Conference 2: Mock Wedding, Usher 3; Preacher 4; Class Play Committee 3, 4; Banquet Program Committee 3.

\section{BLAIR BRASEL}

Cartter, Illinois

A. B. Education

"Men are of two kinds, and he

Was of the kind I'd like to be.

Some preach their virtues and a few

Express their lives by what they do.

That sort was he."

-Guest.

Y. M. C. A. 1, 2, 3, 4, Vice-President 2; Class Vice-President 2, 3, 4; Philadelphian Literary Society 1. 2; Class Play 3; Womanless Wedding 1; Boys' Glee Club 4.

\section{JOSEPHINE AULD}

\section{Cedarville, Ohio}

A. B. Education

"There are wells of sweetness in her:

Her friendship ne'er betrayed another's;

But they who would gain entrance there

Must know her first."

$$
\text { - Selected. }
$$

Y. W. C. A. 1, 2, 3, 4, Secretary 3, President 4; Basketball 2: Girls' Glee Club 2, 3, 4; Mock Wedding 3, 4; Delegate to Y. W. Conference 2; Play Committee 3.
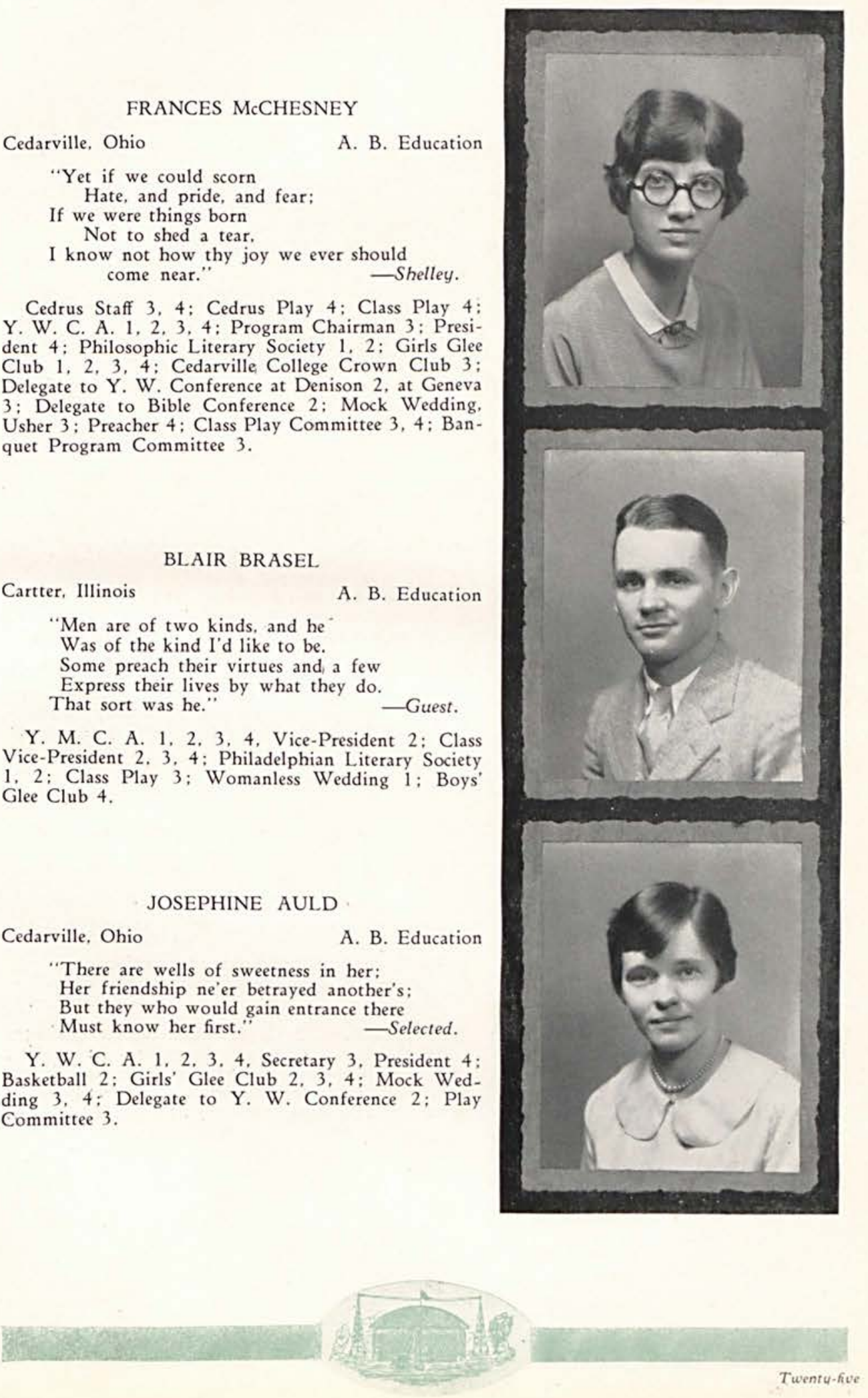


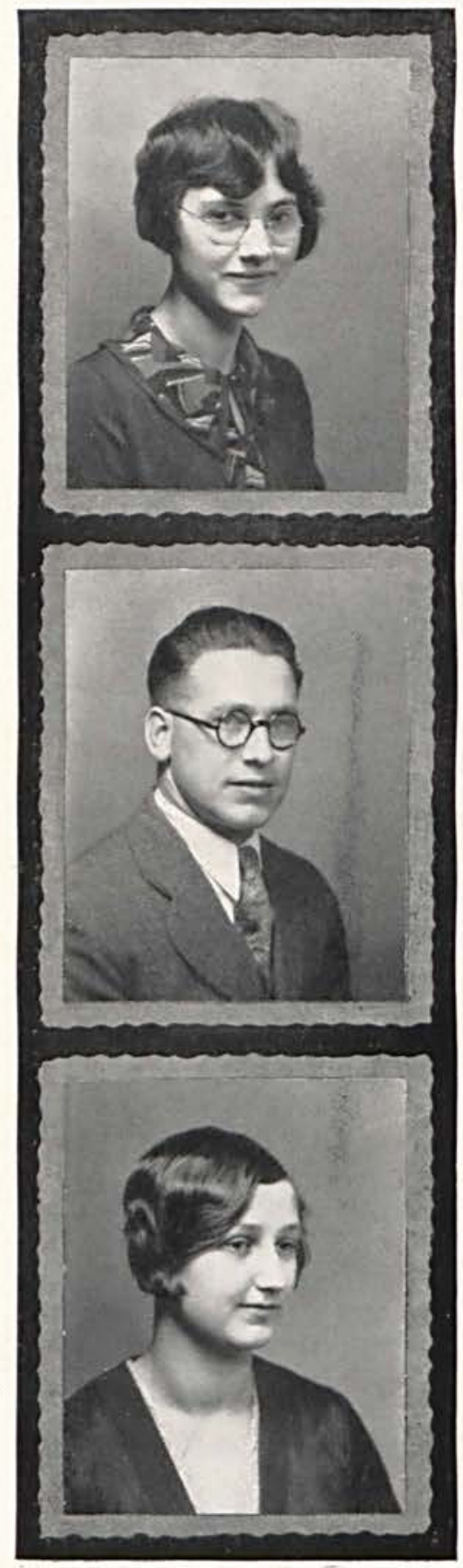

\section{DORTHA FANNING}

Dayton, Ohio

A. B. Education

"Not for glory she'd attained.

Nor for what she had of self,

Were the friends that she had gained,

But for what she had herself.'

-Guest.

Y. W. C. A. 1, 2, 3, 4; World Fellowship Chairman 4: Philosophic Literary Society 2, 3, 4; Class Secretary 4: Class Play 3: Cedrus Staff Play 4: Student Council 4: Girls' Glee Club 3, 4: Mock Wedding Bride 4.

\section{HERBERT L. MAIN}

Beaver Falls, $\mathrm{Pa}$.

Bachelor of Arts

"To live undaunted, unafraid

Of any step that I have made:

To be without pretense or shame

Exactly what men think I am."

-Guest.

Cedarville College Preparatory Department '23-'26: Geneva College 1, 2, 3; Y. M. C. A. 4: Geneva Conference '23, 26: Philosophic Literary Society 4, President 4: Cedar Needles Staff 4: Cedar Day Orator 4: Assistant Football Manager 4.

\section{LILLIAS FORD}

Cedarville, $\mathrm{O}$.

A. B. Education

"Self-reverence, self-knowledge, self-control,

These three alone lead life to sovereign power."

-Tennyson.

Y. W. C. A. 1, 2, 3, 4; Social Service Chairman 3: Membership Campaign Committee 2: Project Leader 3, 4: Crown Club 3: Assistant in English Department 3: Philosophic Literary Society 3, 4; Secretary 3: President 4; Junior Class Play 3: Mock Wedding 4. 


\section{MARY RUTH WHAM}

Cartter, Illinois

A. B. Education

"For transient sorrows, simple wiles,

Praise, blame, love, kisses, tears, and smiles.

A perfect woman, nobly planned,

To warn, to comfort, and command."

-Wadsworth.

Y. W. C. A. 1, 2, 3, 4; Industrial Chairman 3; Girls' Glee Club 2, 3, 4; College Pianist 3, 4; Philadelphian Literary Society 1, 2; Class Play 3; Cedrus Play 4: Cedrus Staff 3, 4; Cedar Needles Staff 2; Minstrel Pianist 2; Director of Minstrel Music 4: Mock Wedding 1, 3, 4; Pianist 2; Cedar Day Pianist 2, 3, 4: Play Committee 3.

\section{DALLAS MARSHALL}

Cedarville, Ohio

Bachelor of Arts

"Who was before him?

Who comes after?

Who follows him finds hardships in his path, For he led."

$$
\text { -Anon. }
$$

Football 1, 2, 3, 4: Basketball 1, 3, 4: Y. M. C. A. 1, 2, 3, 4; Secretary 2, 3, 4; Womanless Wedding 1; Cedar Needles Staff 1, 2; Editor 2; Cedrus Staff 2, 4; Editor-in-Chief 4: Cedrus Staff Play 2, 4; Class Play 3. 4; Y. M. Delegate to Ohio Wesleyan Conference 3; Class President 1, 4; Philosophic Literary Society 4; Chaplain 4; Toastmaster, Junior-Senior Banquet 3; Minstrel 2.

\section{DOROTHY LOUISE WOLFF}

Elizabeth, New Jersey

A. B. Education

"She is a modern woman; she can cope

With man's affairs and work, and yet lose none

Of erstwhile charm; and if occasion calls,

Big business she can just as well direct

As household tasks, and she is good at both." Selected.

Girls' Glee Club 2, 3, 4: Mock Wedding 3, 4; Social Chairman 3: Y. W. C. A. 2, 3: Philadelphian Literary Society 1, 2; Business Manager Class Play 3. 4: Mother and Daughter Banquet Committee 3, 4; Junior-Senior Banquet Committee 3: Cedar Day Committee 2; Class Treasurer 3; Play Committee 4.
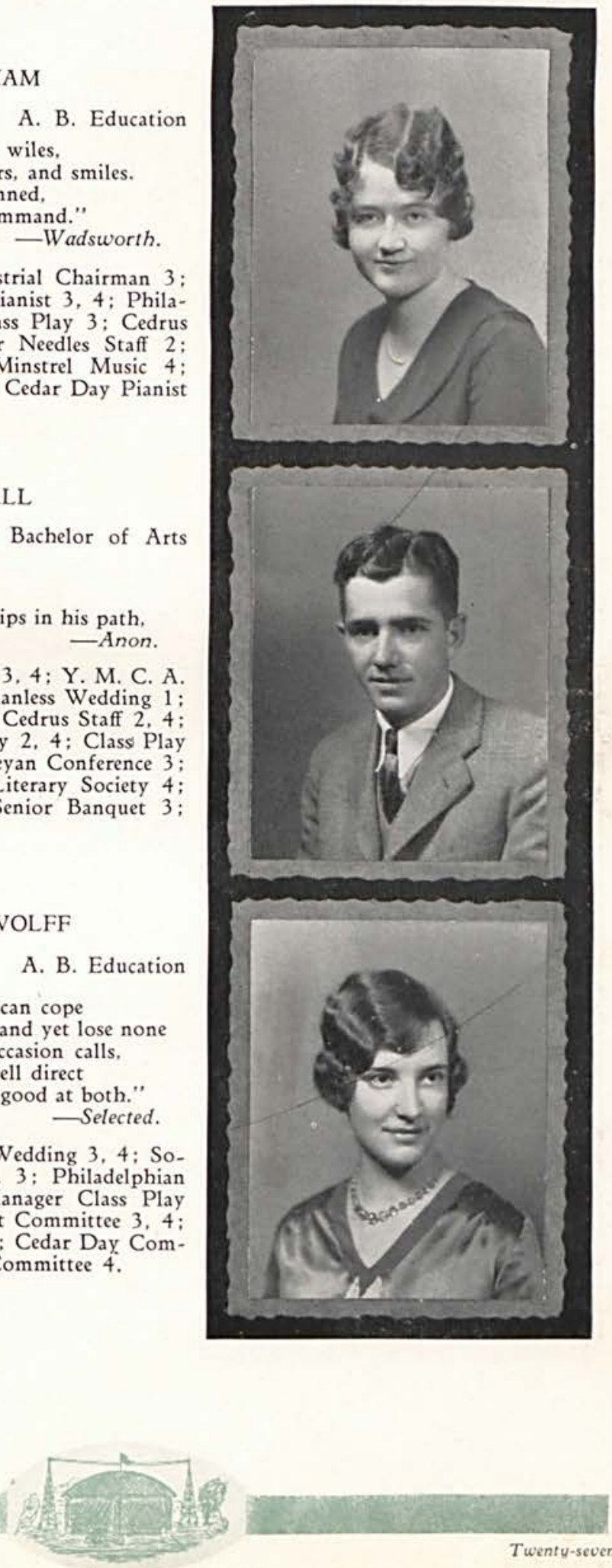

Twentu-seven 

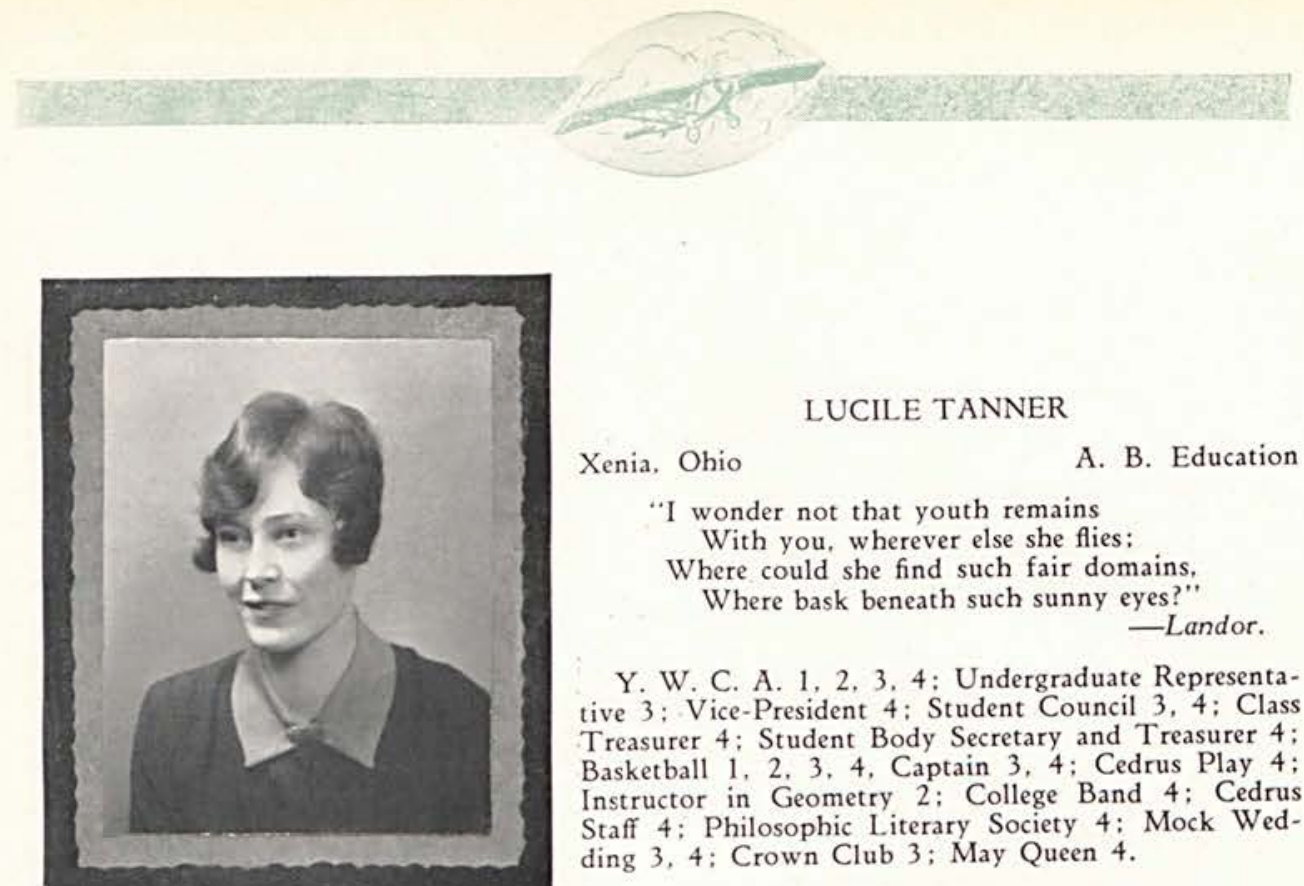

\section{LUCILE TANNER}

Xenia, Ohio

A. B. Education

"I wonder not that youth remains

With you, wherever else she flies:

Where could she find such fair domains,

Where bask beneath such sunny eyes?"

$$
\text { - Landor. }
$$

Y. W. C. A. 1, 2, 3, 4: Undergraduate Representative 3: Vice-President 4: Student Council 3, 4; Class Treasurer 4: Student Body Secretary and Treasurer 4; Basketball 1, 2, 3, 4, Captain 3, 4; Cedrus Play 4; Instructor in Geometry 2; College Band 4; Cedrus Staff 4: Philosophic Literary Society 4: Mock Wedding 3, 4: Crown Club 3; May Queen 4.

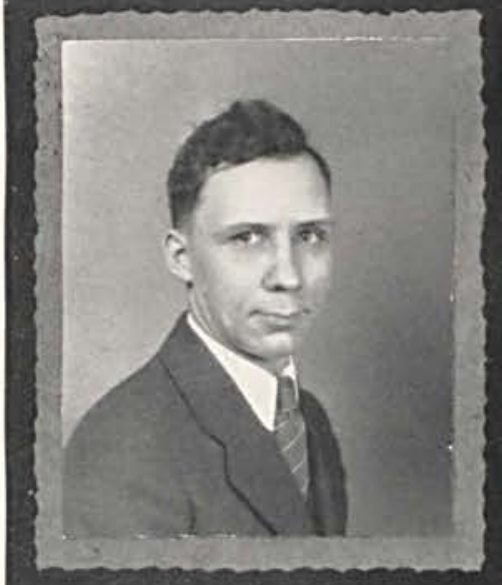

FRANK L. GRAHAM

Industry, $\mathrm{Pa}$.

A. B. Education

"If yu hav' got a reel good wife, kepe perfeckly still, and thank God every twenty minnits for it."

-Josh Billings.

Y. M. C. A. 1, 2, 3, 4; Social Chairman 2, 3, 4; Philosophic Literary Society 3, 4: President 3: Steward of College Club 4; Class Play 3; Cedrus Play 4: Class Play 4: Cheer Leader 1, 2; Womanless Wedding 1: Band Treasurer 4; Boys' Glee Club 4; Chemistry Laboratory Ass't 4.

\section{ELIZABETH HAYDOCK GRAHAM.}

Wilmington, Ohio

A. B. Education

"Two heads in council, two beside the hearth,

Two in the tangle business of the world,

Two in the liberal offices of life."

- Tennyson.

Y. W. C. A. 1, 2, 3, 4. Philadelphia Literary Society 1,2: Philisophic Literary Society 3, 4; College Orchestra 1, 2: Glee Club 3, 4: Stage Manager Junior Play 3; Stage Manager Cedrus Play 4.

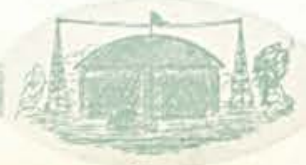




\section{NEWTON MANTLE}

New Jasper, Ohio

Bachelor of Arts

"Who comprehends his trust, and to the same

Keeps faithful with a singleness of aim;

And therefore does not stoop, nor lie in wait

For wealth or honors, or for worldly state;

Whom they must follow."

\section{-Wordsworth.}

Miami University 1: Cedarville College Seminary Department 3, 4: Y. M. C. A. 3, 4: Elected President 4: Resigned because of scarcity of time to fulfill his duties properly: Became Vice-President.

\section{MRS. CAMMIE GORMLEY}

Cedarville, Ohio

A. B. Education

"She has a world of ready wealth.

Our wishes and hearts to bless-

Spontaneous wisdom breathed by health.

Truth breathed by cheerfulness."

$$
\text { -Wordsworth. }
$$

Cedarville College Crown Club, 3.

\section{ROGER V. STORMONT}

Cedarville, Ohio

Bachelor of Arts

"The friend in every time of need

The doer of the daring deed

The clean and generous handed man

That is a real American."

-Guest.

Y. M. C. A. 1, 2, 3, 4; Philadelphian Literary Society 1, 2, 3; Football and Basketball Trainer 1, 2 3: Republican Keynote Speaker and Temporary Chairman at Mock Convention 2.
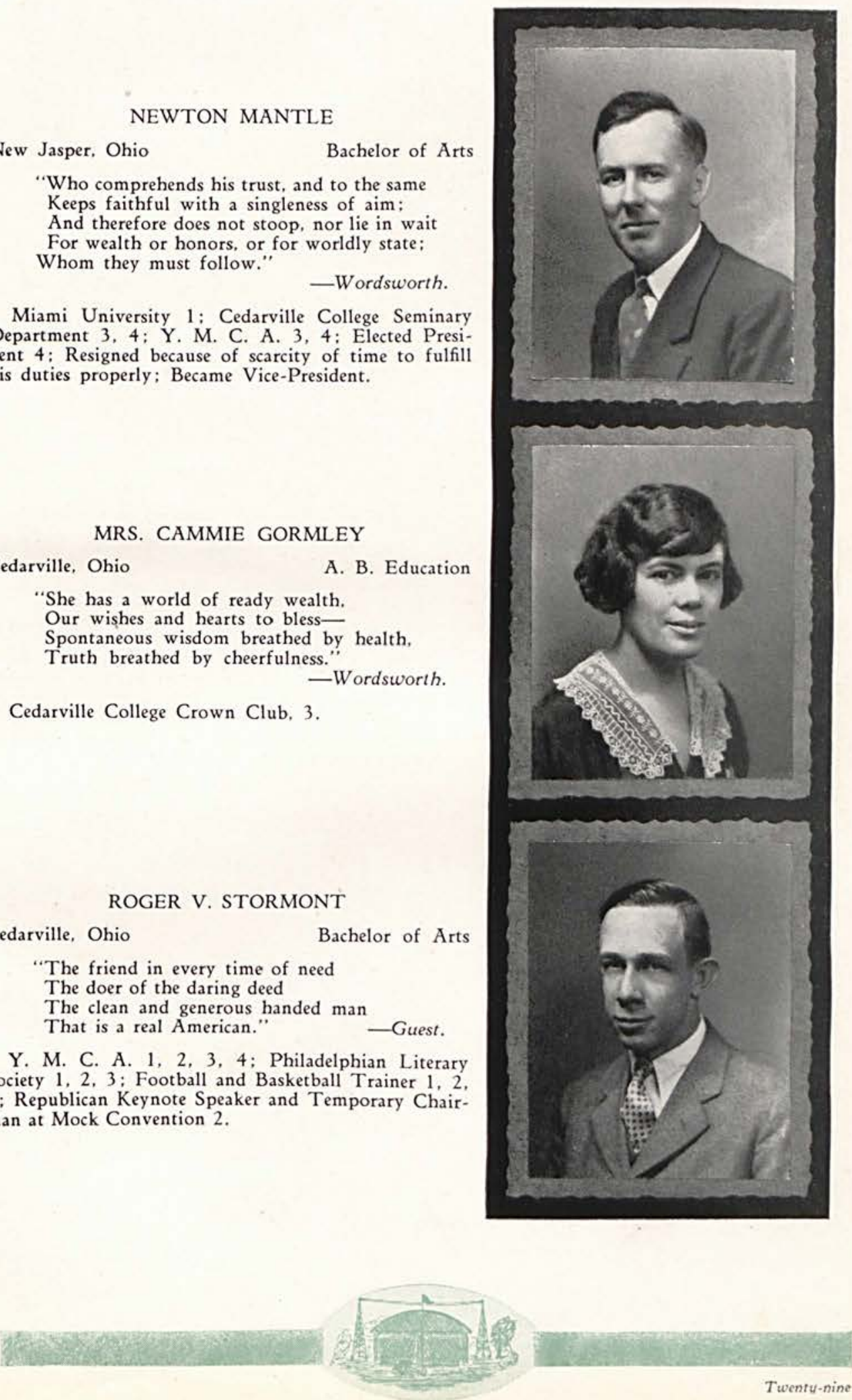


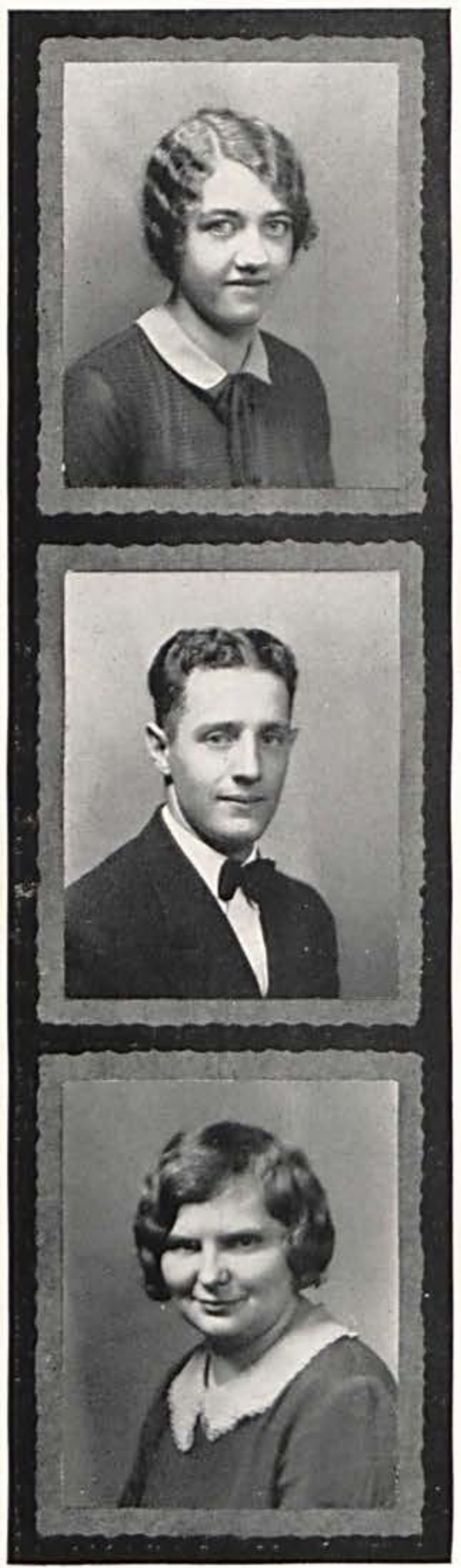

\section{FRANCES BRADLEY}

Xenia, Ohio

B. S. Education

"My crown is in my heart, not in my head,

Not decked with diamonds and India stones.

Nor to be seen: my crown is called content,

A crown it is, that seldom kings en joy."

- Selected.

Y. W. C. A. 1, 2, 3, 4: Greene County Normal 1: Cedarville College State Normal 2, 3, 4; Operetta 1; Class Play 3; Mock Wedding 4: Cedar Day 3; MotherDaughter Banquet Committee 3, 4 .

\section{PAUL TANNER}

Xenia, Ohio

A. B. Education

"How happy is he born and taught

That serveth not another's will,

Whose armor is his honest thought,

And simple truth his utmost skill." -Wotton.

Baseball 1, 2, 3, 4: Cedar Needles 2, 3, 4; Philosophic Literary Society 1, 2, 3, 4: Sergeant at Arms 2. Vice-President 3, Chaplain 4: Y. M. C. A. 1, 2, 3 , 4, Treasurer 3, 4; Business Manager Cedrus 4; Class Play 3: Cedrus Play 4: Class President 3; President of Student Body 4: College Band 4.

\section{ELIZABETH BADSTUBER}

Cleveland, Ohio

B. S. Education

"Where youth and laughter lingered long

To quaff delight with wanton song

And warm caress."

Y. W. C. A. 2, 3, 4: Philosophic Literary Society 3. 4: Mock Wedding 1, 3, 4; Class Play 4: Faculty Impersonator $1,2,3,4$. 



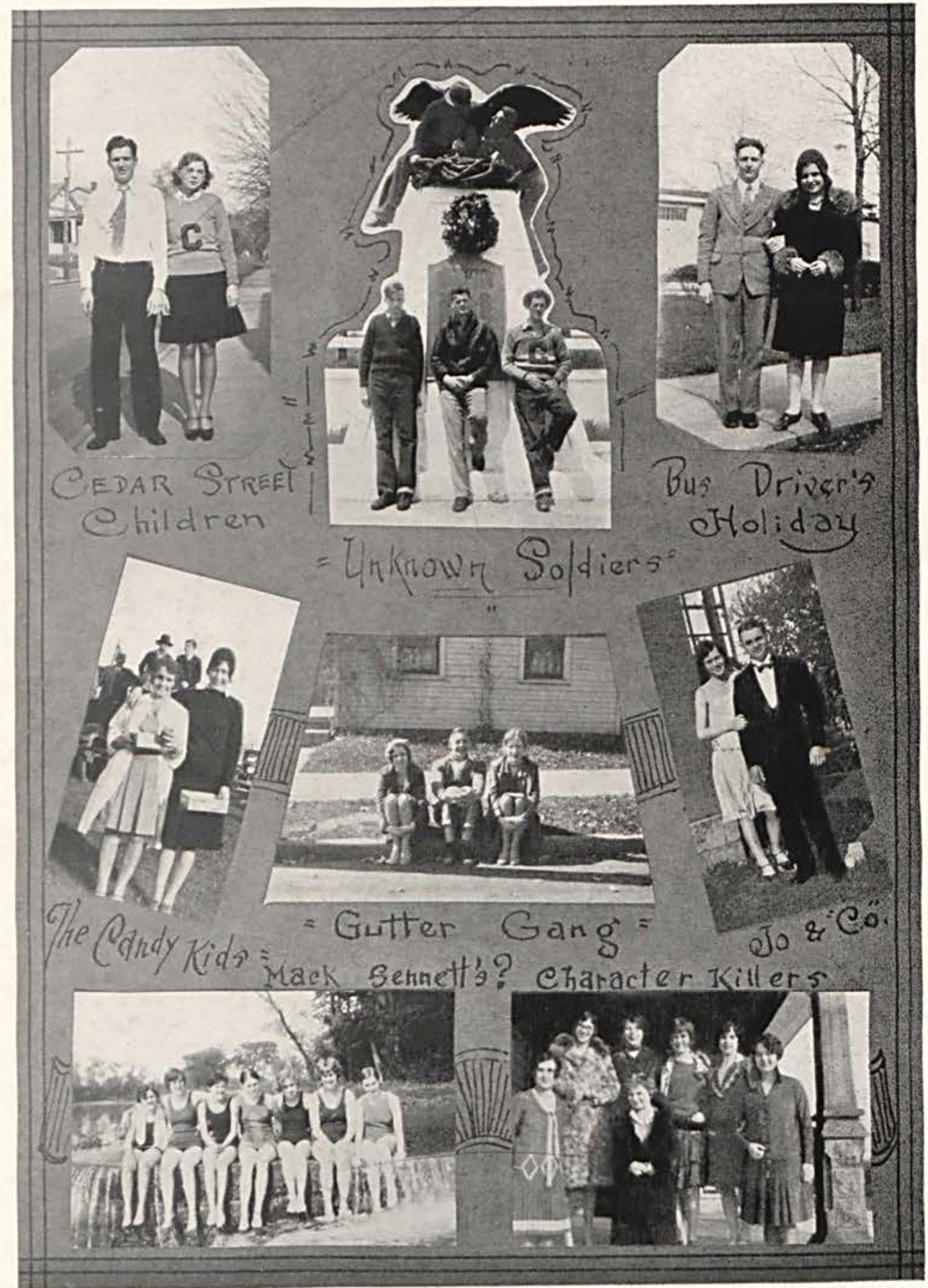




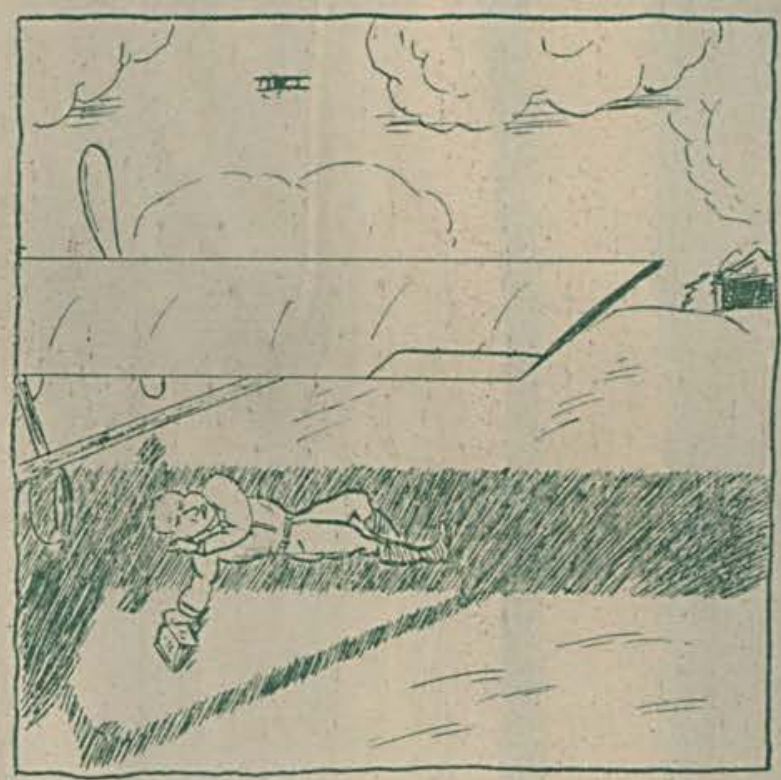

Juniors 


\section{Juniors}

Oh, the Juniors are a jolly bunch

They worty none at all

It makes them laugh to see a calf

Go out for the old football.

Yea! Here's to you and may you like Santy grow So fat with laughing yout bay window will shake Like raspbetry jam. 


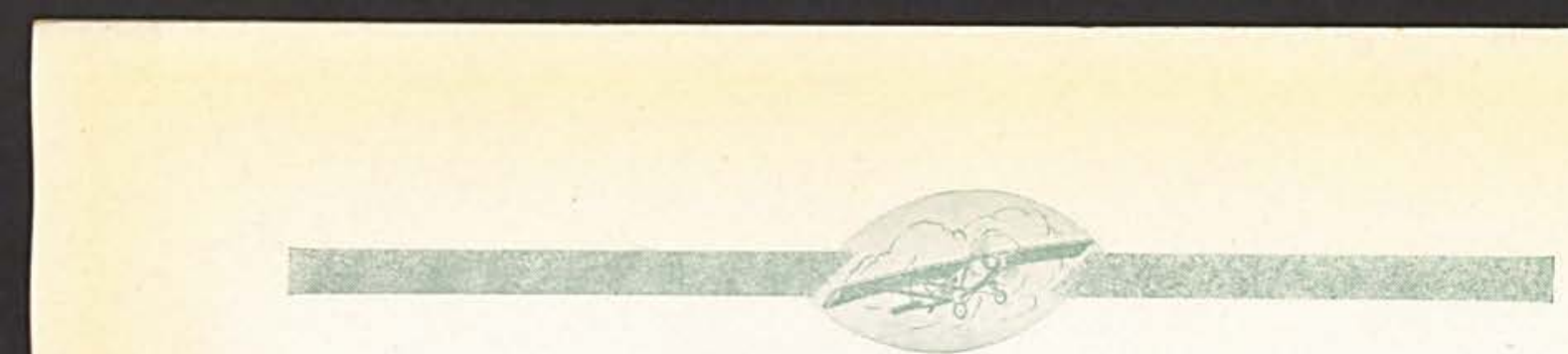

\section{The Trip is Almost $\mathrm{O}^{\prime} \mathrm{er}$}

One more dip and we'll glide along

Out in midstream where the current's strong,

Where the salmon flash and the small fish dash

At the sudden dip of the supple ash;

Away we go to the river's end,

Driftin' along where the current sends.

Lean back in your seats and stretch your limbs

And watch the fish as he upward swims

For the water's clear, as the twilight's here;

And list to the noisy wood folk near,

They assemble now on the woody shore

And call for their mates the forest o'er.

The rapids are near, oh, classmates of mine,

Can't you see them ahead where the boulders shine?

The birds in the trees singing melodies,

They know full well how these rocks can seize

And smash in a flash a staunch canoe,

With anyone in it like me and you.

Lift up the paddle again on high,

For the treacherous rapids are safely by,

And now for home let the old boat roam,

For we've passed the worst of the river's foam,

But _._. listen once more to the folks on shore,

For this glorious trip is almost o'er.

George W. Davis, ' 30.

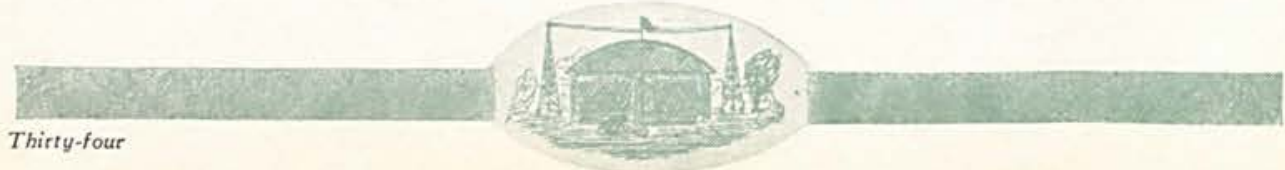





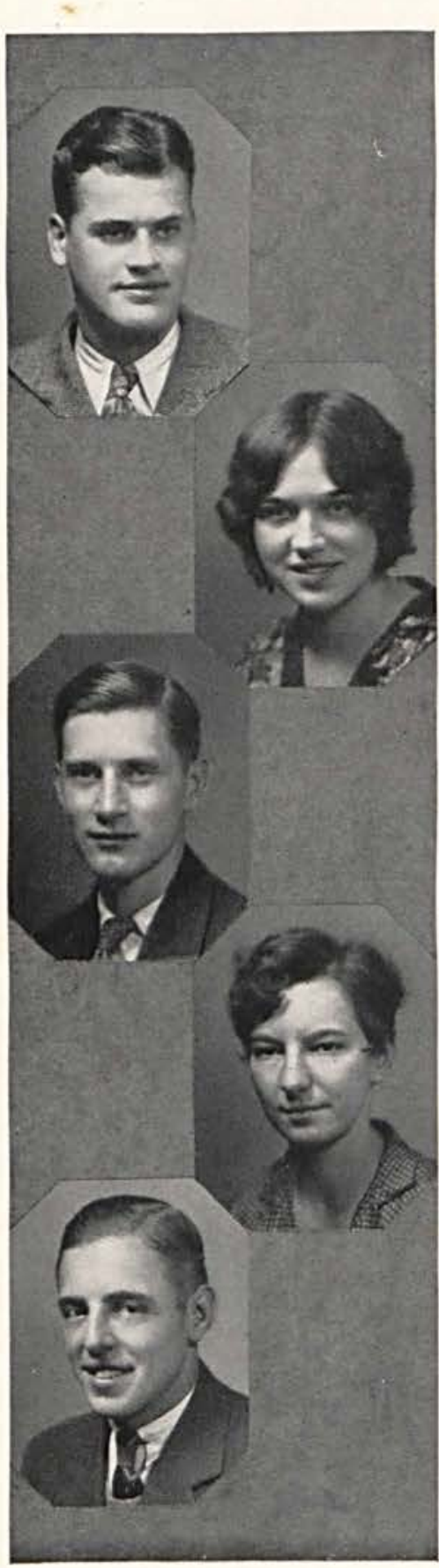

WENDELL BOYER

He comes from Good Hope but Springfield is a good town, too. Is a mean singer and a fine athlete. Was Duke for a night.

SARAH RUMBAUGH

Our star athlete of the obstinate sex. We know now why she is always on the eats committee. Did you see her in Kempy?

DONALD ALLEN

Gone but not forgotten is our Belle Center lad. Loves the basketball court and cares little for the recitation hall

IRENE TOBIAS

Why is "Bob" Wilson going to be a farmer? Ask Irene. She sure must stay out late, she never gets to school at eight.

\section{ALBERT TURNER}

An all around athlete and a ladies man par excellence. Who's your girl now Koty?

Former member of the Weasel's nest. 


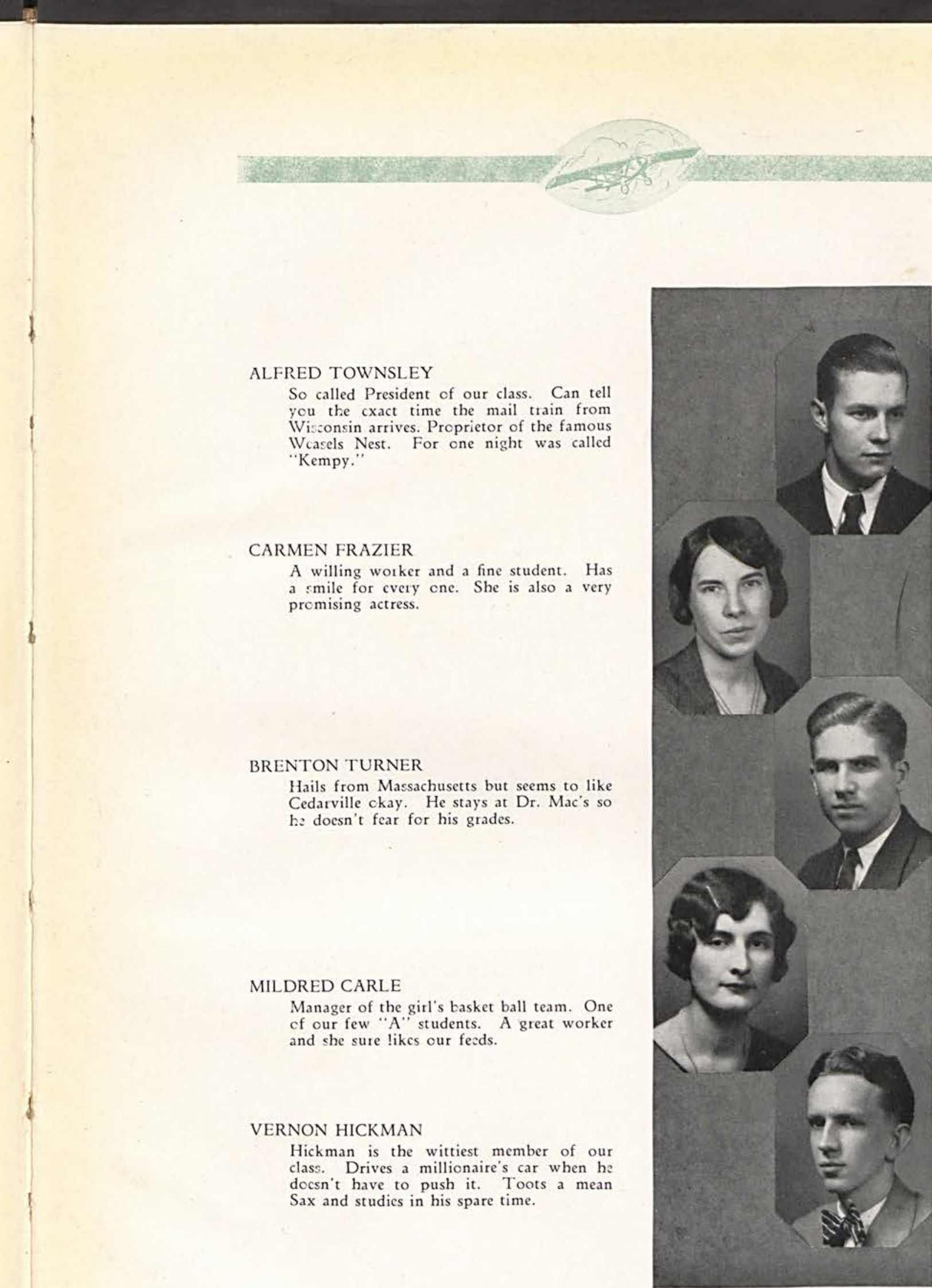

So called President of our class. Can tell you the cxact time the mail train from

Visconsin arrives. Proprietor of the famous V casels Nest. For one night was called "Kempy.

A willing worker and a fine student. Has
a smile for cvery cne. She is also a very promising actress.

TON TURNER Cedarville ckay. He stays at Dr. Mac's so h2 docsn't fear for his grades. cf our few "A" students. A great worke and she sure likes our feeds.

\section{VERNON HICKMAN}

Hickman is the wittiest member of our class. Drives a millionaire's car when he docsn't have to push it. Toots a mean Sax and studies in his spare time. 

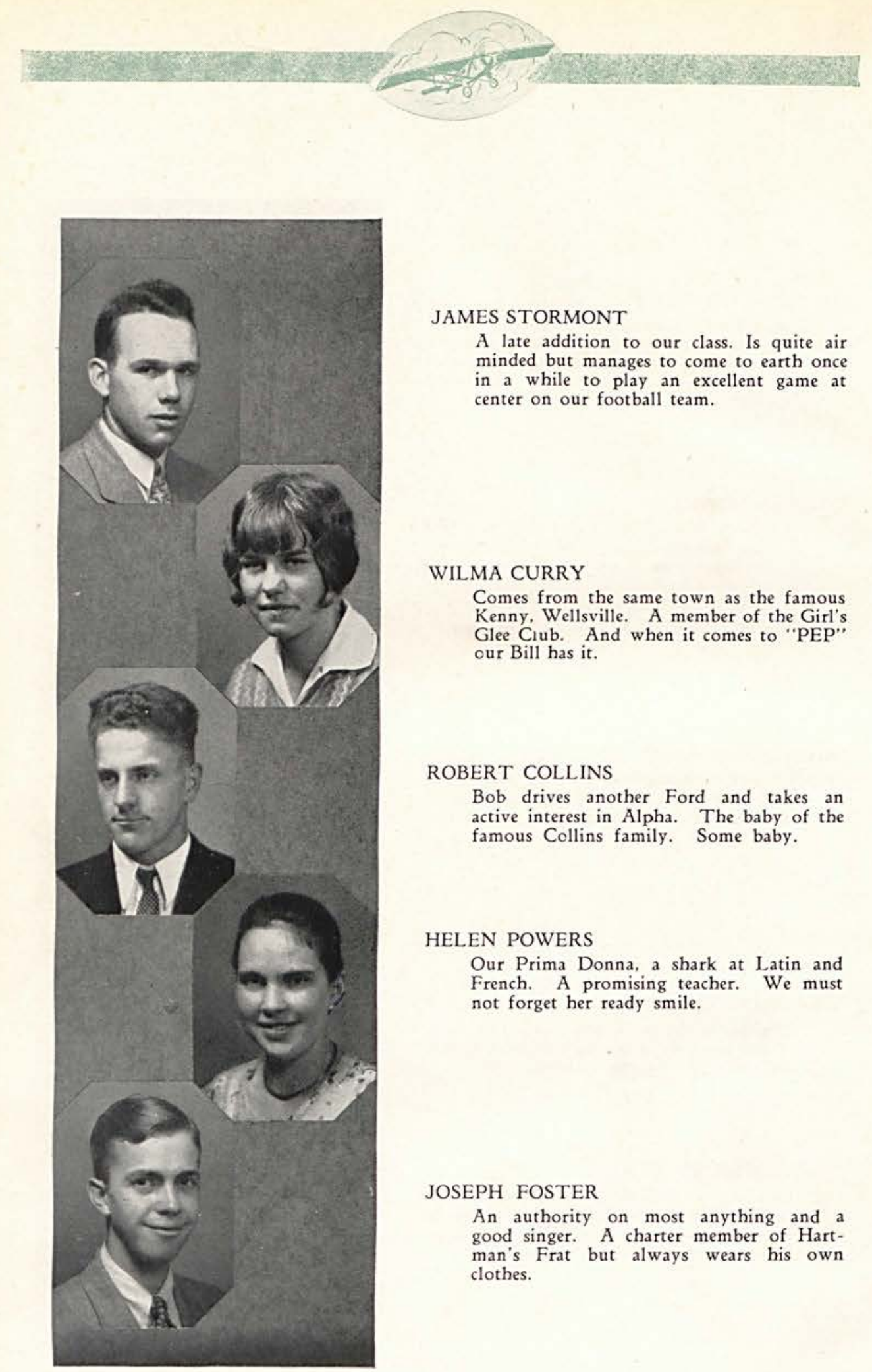

\section{JAMES STORMONT}

A late addition to our class. Is quite air minded but manages to come to earth once in a while to play an excellent game at center on our football team.

\section{WILMA CURRY}

Comes from the same town as the famous Kenny. Wellsville. A member of the Girl's Glee Club. And when it comes to "PEP" our Bill has it.

\section{ROBERT COLLINS}

Bob drives another Ford and takes an active interest in Alpha. The baby of the famous Collins family. Some baby.

\section{HELEN POWERS}

Our Prima Donna, a shark at Latin and French. A promising teacher. We must not forget her ready smile.

\section{JOSEPH FOSTER}

An authority on most anything and a good singer. A charter member of Hartman's Frat but always wears his own clothes.
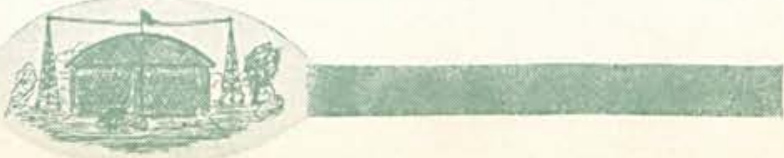


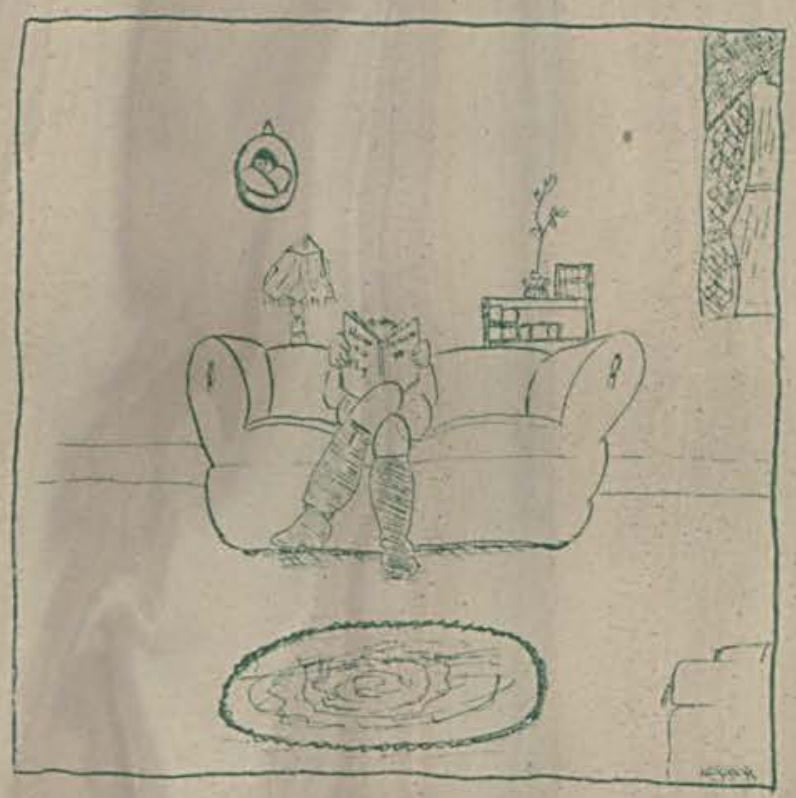

\section{Sophomares}





\section{Sophomores}

Oh, the Sophs are Freshies one yeat old And wiser by a year;

At least they think they are and so

Right now let's give a cheet

For "Sophs"

"So Smooth"

"So Powerful"

"So Soft." 


\section{Our College}

You may talk about the mountains of Virginia, You may speak about the plains of Illinois,

But you cannot find a spot to me that's grander Than the college I attended as a boy.

I recall the lessons there the school has taught me,

And the passing years but makes them plainer still.

How I love that dear old college in Ohio.

How I love that dear old school called Cedarville.

Some day in the distant future we shall honor That old school that's meant so much to us,

And we'll think about our many constant friendships As the years slip slowly way from us.

I can challenge you my friends to find another, Just another more enshrined in hearts of men.

Than our dear old Alma Mater, thru the ages

Teaching leadership to many girls and men.

Cedarville our Alma Mater, we all love her

And her name means very much to all:

So we hope she stands thruout the many ages,

Giving learning to those who hear the call.

George W. Davis, '30. 

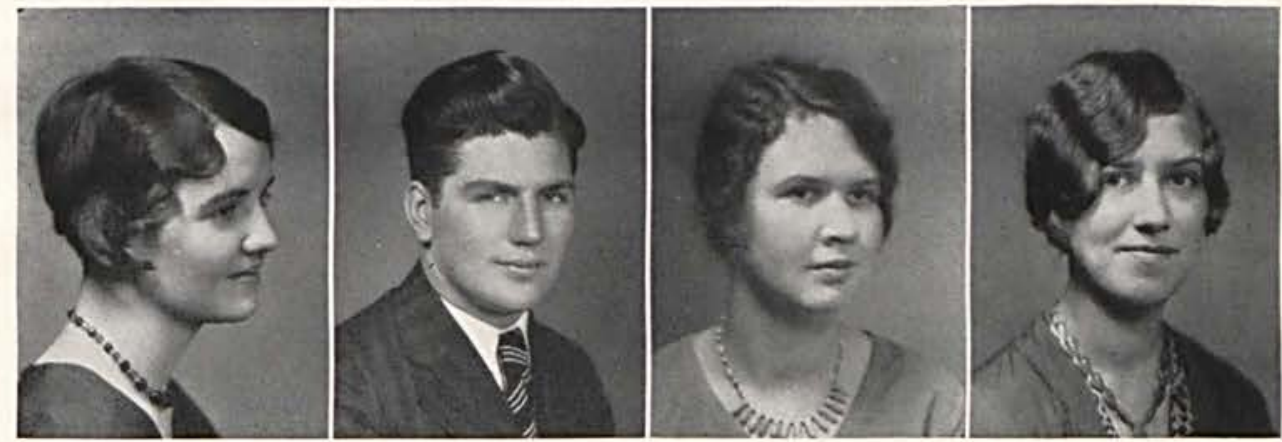

\section{Sophomore Class}

Lenora Skinnell

President

Edward Irons

Vice President

Esther Mae Hartman

Secretary

Gertrude Martin

Treasurer

T the fall of 1928, thirty Freshmen entered Cedarville College. After having been properly initiated by the upper classmen, the Freshies began to try to do their bit both in the classroom and out. They were very prominent in athletics and the Girl's Glee Club.

Twenty-five of these Freshies returned in 1929 to enter the ranks as Sophomores. By that time they had gotten into the full swing of college activities. Last fall some of the best football players were Sophomores. The girls went out for basketball and glee club and have performed well in both. Several of the Sophomore boys have entered the Boy's Glee Club which has been recently organized.

However, the Sophomores have not allowed all the extra-curricular activities to interfere seriously with their classwork. We hope to see all of them back next year doing still better work.

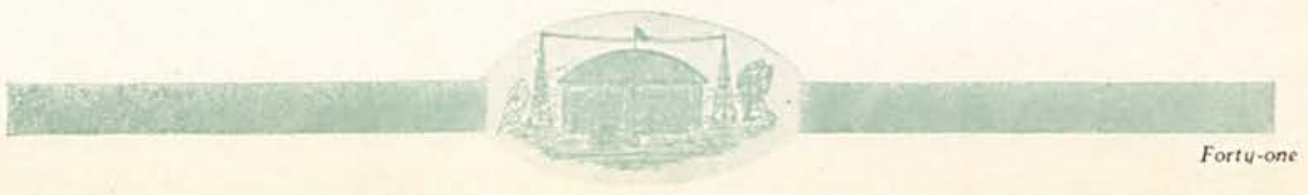



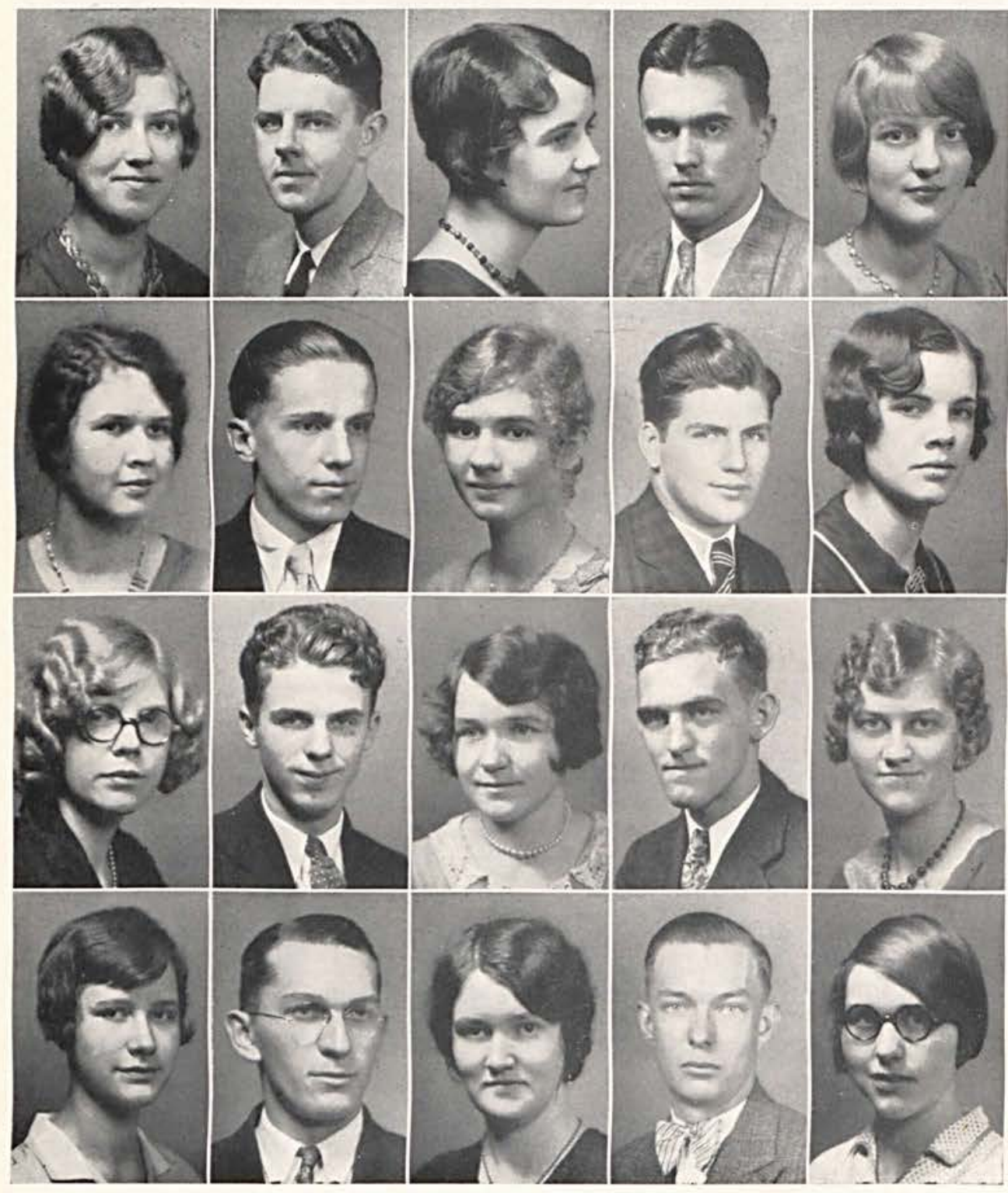

E. Hartman

R. Marshall

L. Reed

N. Creswel

L. Skinnell

W. Bradley

C. Dean

E. Hinton

E. Prons

H. Flatter

M. Waddle

M. Chancet

B. Bryant 



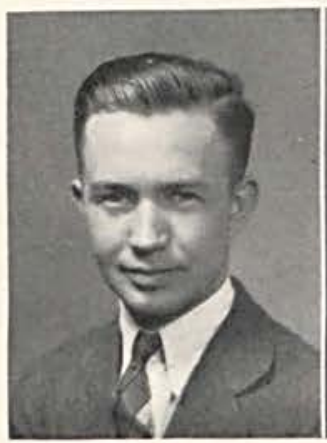

H. Auld

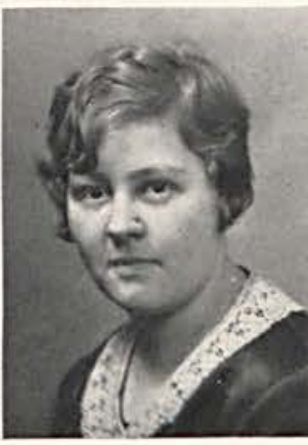

C. Rife

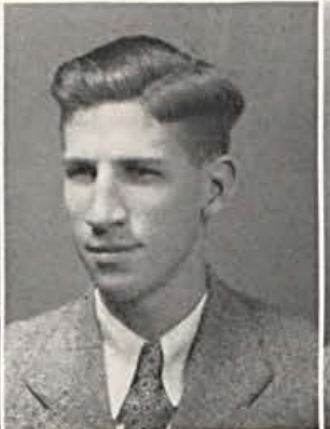

R. Duffey

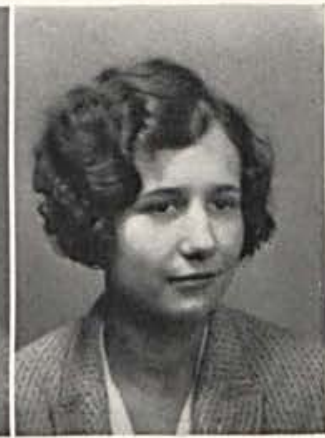

G. Hamman

\section{Special Students}

\section{HARVEY Auld}

We thought we were rid of Harvey last year when he received his A.B., but he fooled us, much to our liking. After discussing the situation with $\mathrm{Mr}$. Elder. president of the bank, for several weeks Mr. Elder decided he could spare Harvey for a couple of hours a day. In those two hours he has returned to C.C. and finished his educational work and a major in science. Not bad for a lad his size. Here's to Harvey, "The Immortal Football Manager and Baseball Rooter.'

\section{CHRISTINE RIFE}

She really belongs with the Juniors but since she changed her course and we had the correct number of Junior pictures without her's we put her over here where we can give her a little more attention. Christine decided she wanted a B.S. in Education so now is in the Normal Department. More power to you, Shorty.

\section{ROBERT DUFFEY}

Bob spent his first year with us in '27-'28. Then decided to go to Miami and major in Physical Education where he labored in '28-'29. Found out he could get what he wanted at C.C. the first semester this year so we found him again in our midst and indeed we're glad to have him. Bob originated the College Band. May this organization continue to grow and learn to honor him for its creation.

\section{Gertrude Hamman}

Miss Hamman is now in the Music Department after spending a year and a half in regular college work. We are sorry she is not with us more and are always glad to have her pleasing countenance with us. 


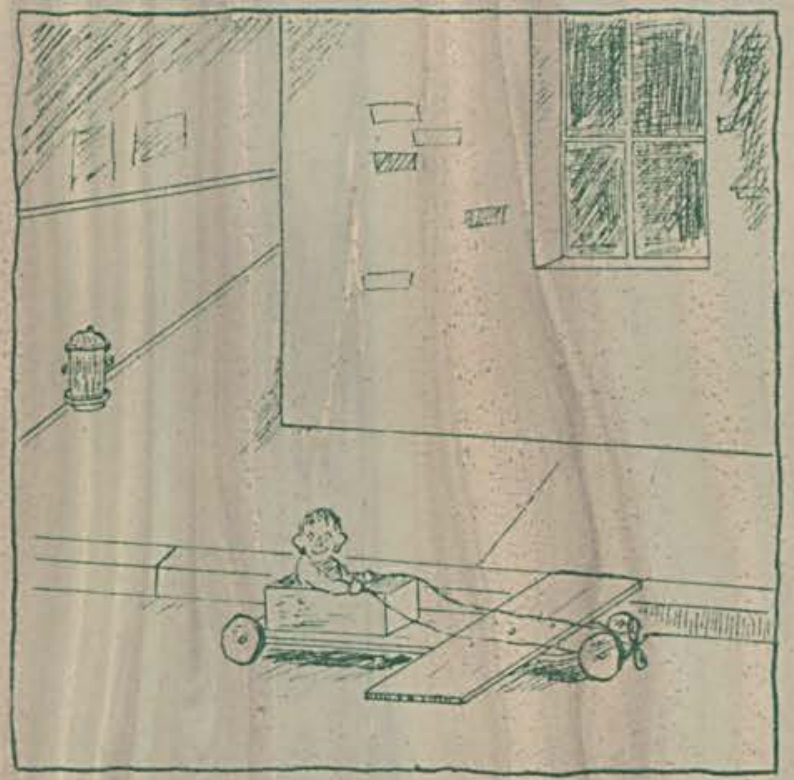

J resthmen 


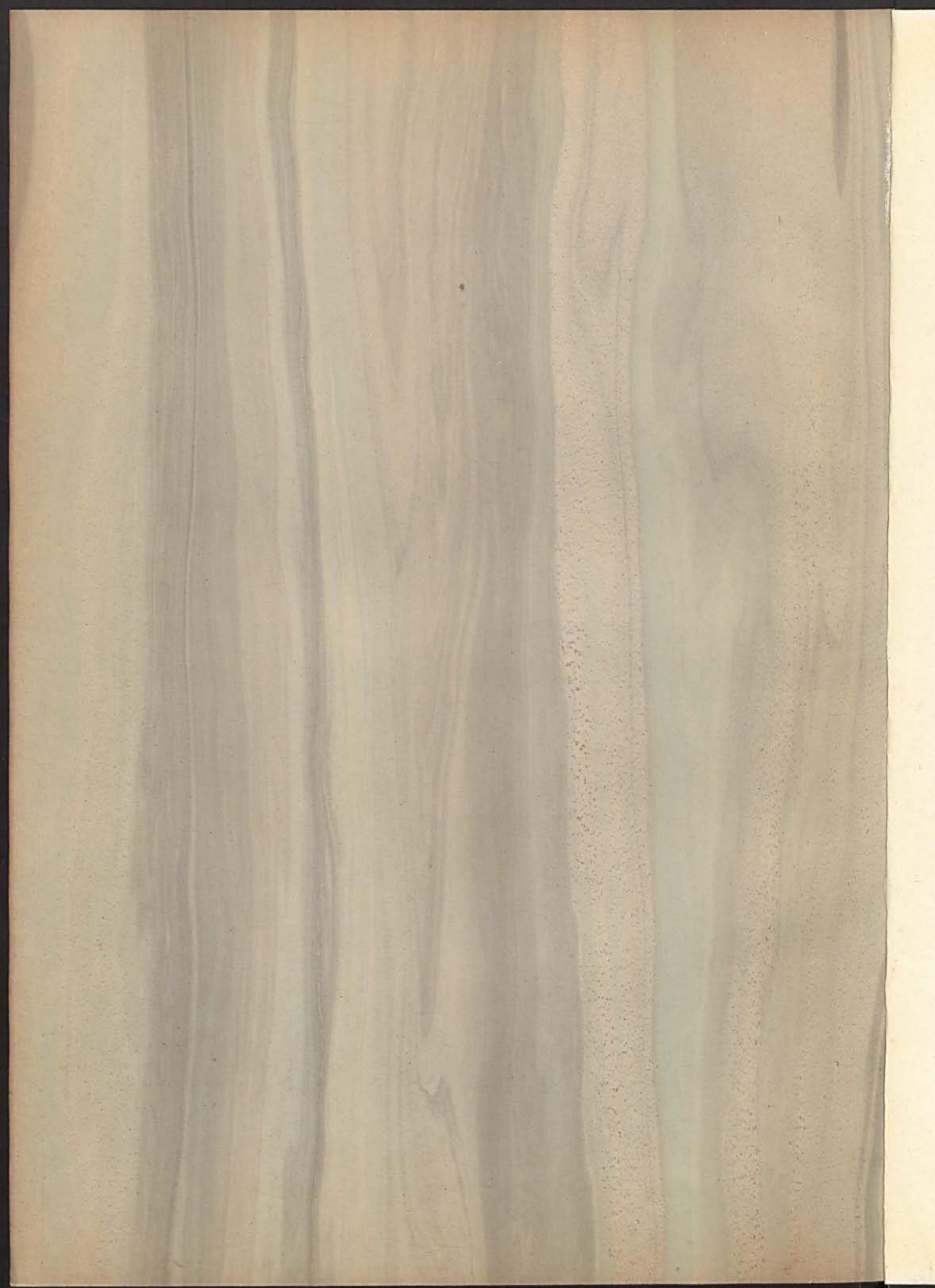




\section{Freshmen}

Oh, the Freshies are the babies;

But such infants you ne'er saw;

We hope they'll stay another year,

But now let's give a tah

"For Bigger and Better Freshmen." 


\title{
That Cedarville Chum of Mine
}

"When the toil of day is ended,

When the twilight shadows fall,

When the fitful gleaming firelight

Casts weird forms upon the wall,

It is then for happy dreaming

I all anxious cares resign,

And greet again in mem'ry land,

That college chum of mine.

\author{
"But after all bright visions \\ Of the other friends depart, \\ The thought of one stays with me, \\ Treasured deep within my heart; \\ And I trust that till the sun of life \\ Shall cease for me to shine, \\ I shall never lose the mem'ry of \\ That Cedarville chum of mine."
}

-From an Old Cedrus. 


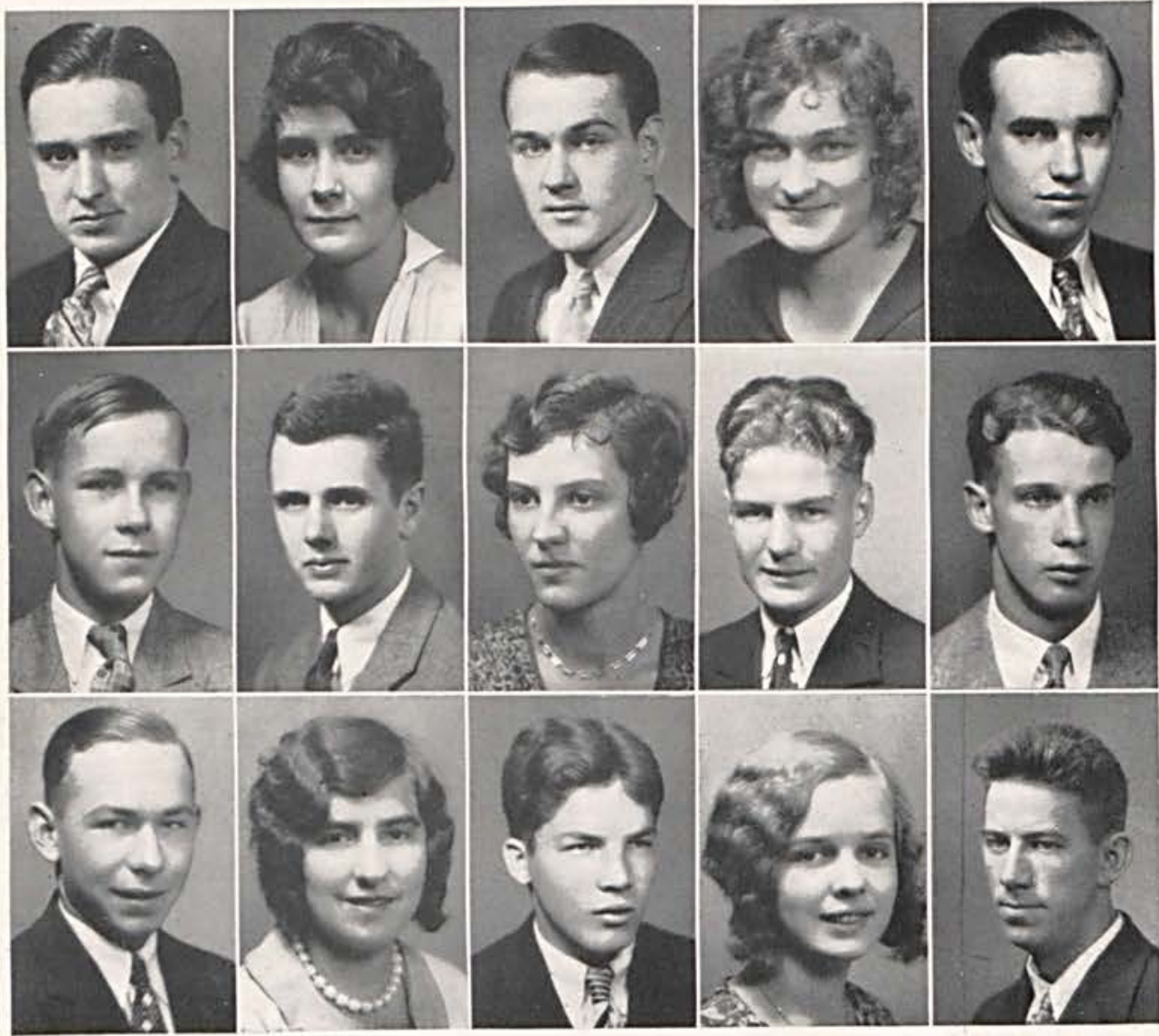

A. Deeter

E. Kinnison

D. Swaby

R. Marshall

B. Holloway

B. Elias

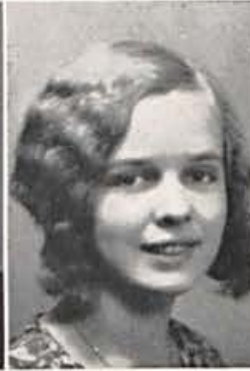

R. Smith
W. Ballard

A. Miller

J. Osborne

R. Garlough
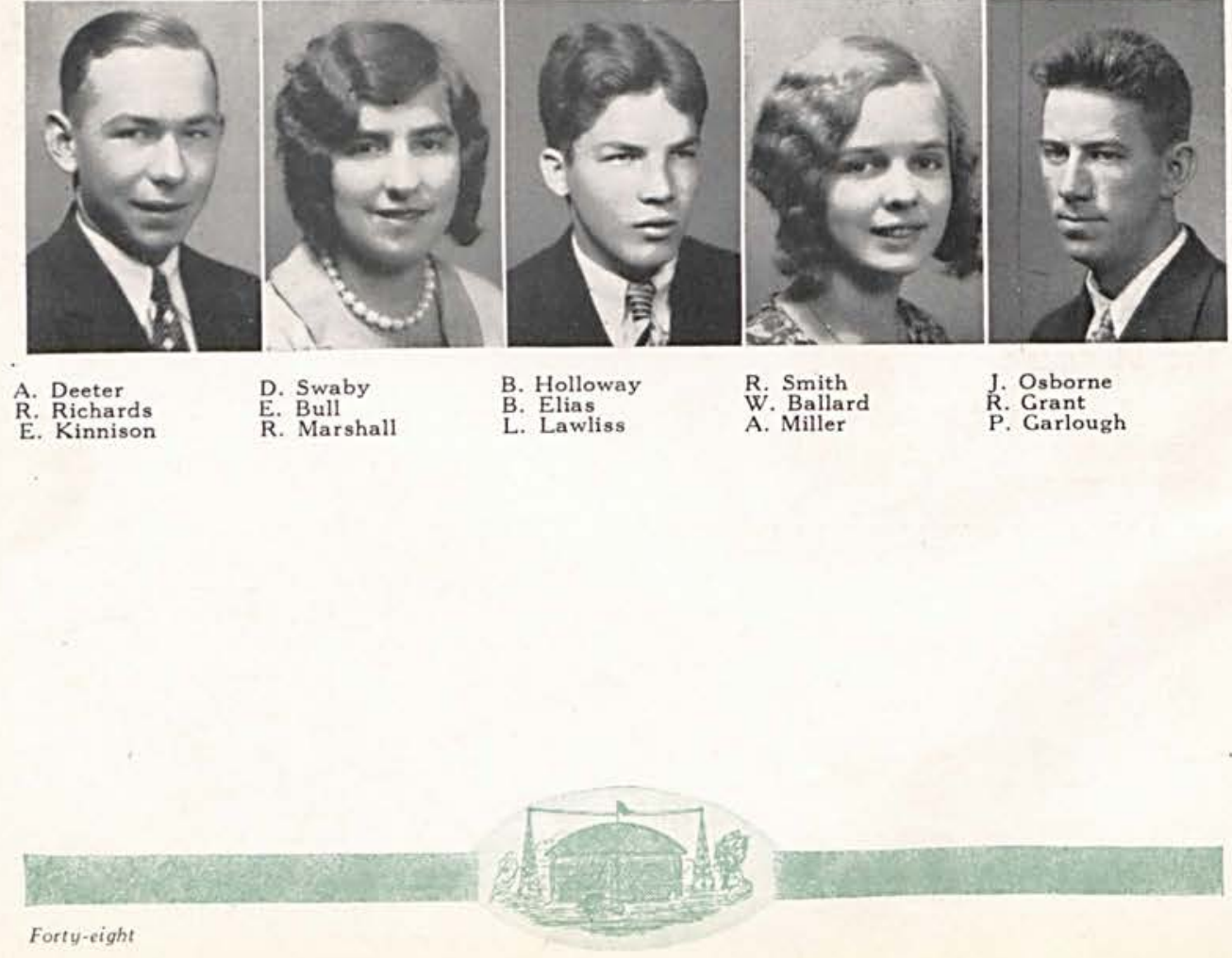

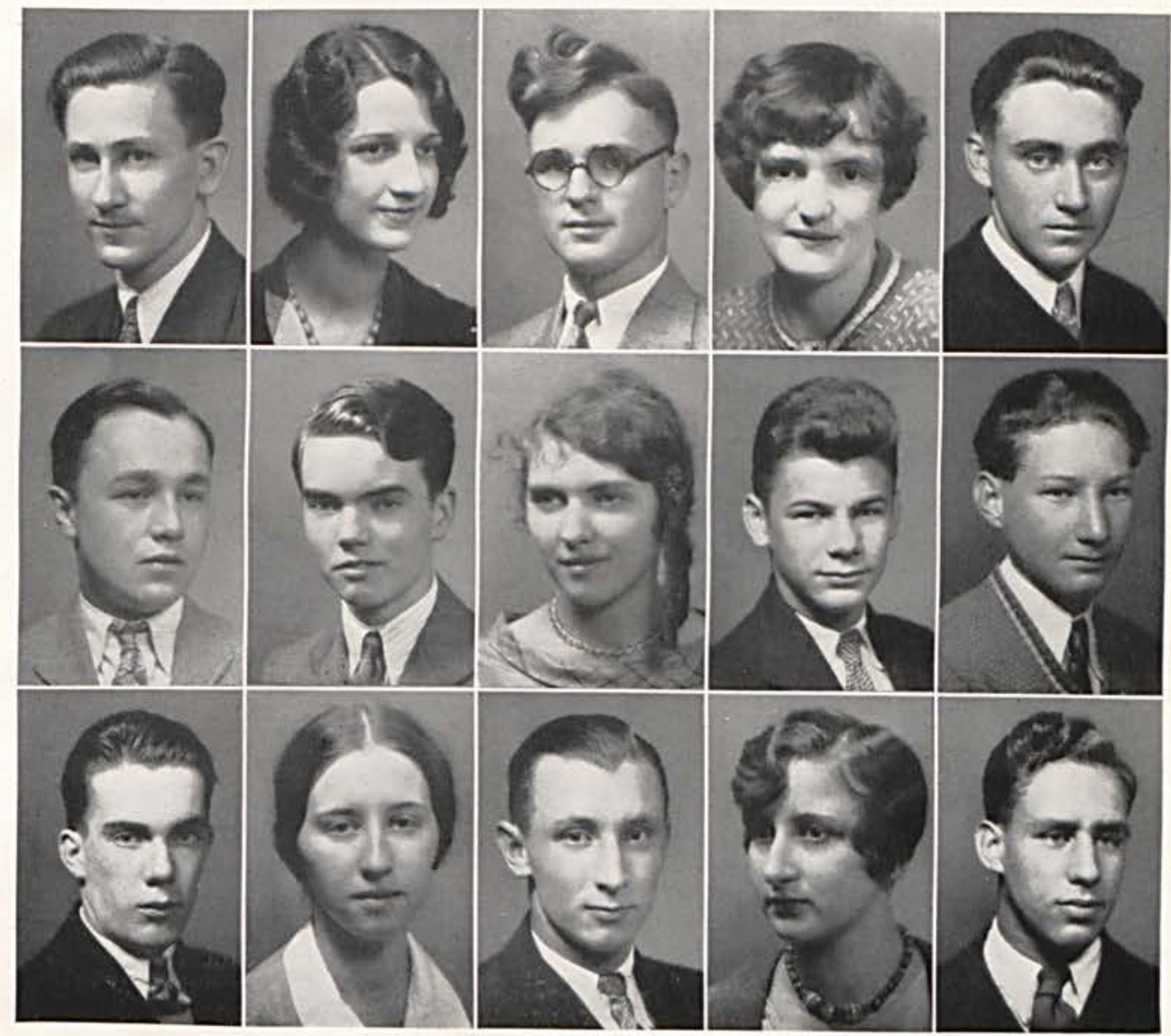

L. Lumpkin

W. Lumpkin

A. Phillips

V. Harbough

C. Moody

C. NícDonald

E. Brigner
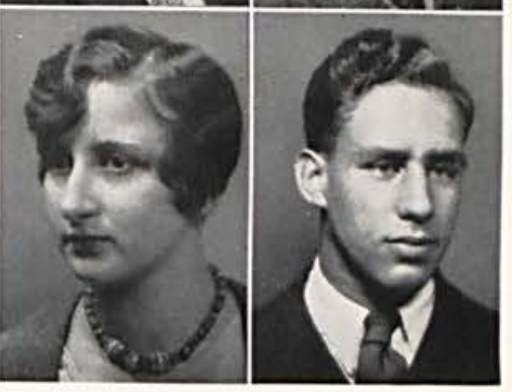

$\begin{array}{ll}\text { D. Merriman } & \text { C. Spencer } \\ \text { H. Baker } & \text { C. Bost }\end{array}$

H. Baker
J. Modic

H. Scott
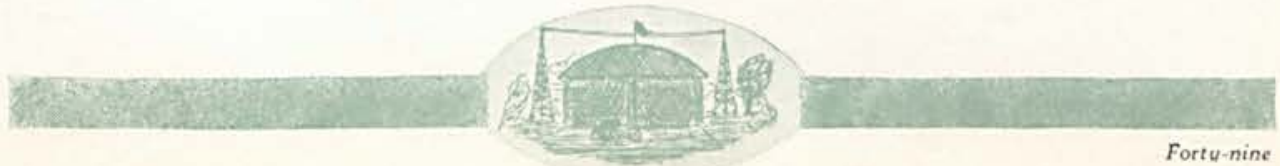

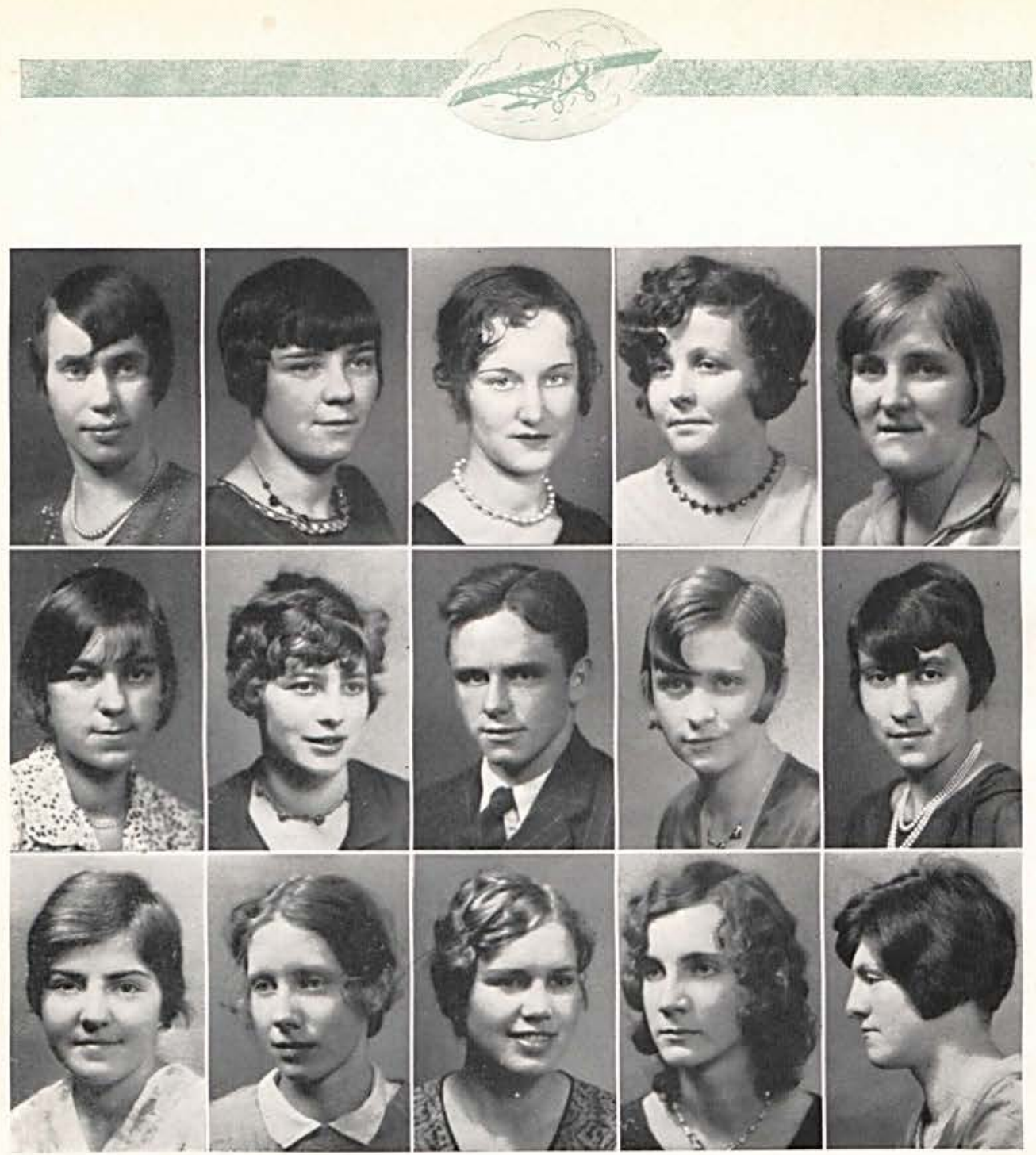

J. Trumbo

J. Kelly
M. Roseberry

A. Keckic

M. Cotton
L. Britcher

R. Johnston

M. Rife

L. Kilgore
E. McCoy
L. Stroup

R. Baird

R. Sprinkle

M. Anders

\section{First Year Normal}

ND it did come to pass that in the year of our Lord 1929 that a great A clamor arose from the multitude attending the College of Cedarville, in that such a sophisticated group of First Year Normals had appeared on the campus.

Of course we had many hard knocks to encounter, among which first appeared the unintelligent entrance exams, and secondly, the Freshmen initiation, but we faced it all as all good sports should. We contributed to the crowds attending the ball games and social functions. Altho we were unable to donate any regular players for the athletic teams, we did give three officers to the Freshmen class. 



\section{Music}

$\mathrm{T}$

HE Department of Music, under the direction of Professor Lydia A. Berkley, assisted by Mrs. Helen Laughlin Corry, is located in the Carnegie Library.

Professor Berkley, who is a graduate of Lincoln Conservatory of Music, and has taken work at the Hiram Conservatory and that of Oberlin, offers courses in Organ and Piano. Professor Corry, the voice instructor, is a graduate of the college of Wooster.

The Girls' Glee Club, trained by Professor Berkley, is made up of about thirty voices. The Boys' Glee Club, under the same direction, is made up of about twenty voices. Although the latter club was late in starting, it has added pep to the Music Department.

During the latter part of February, the Girls' Glee Club gave a concert of beautiful pieces in the First Presbyterian Church. It was well attended and enjoyed by all.

The Music Department offers courses in Public School Music, Notation, Harmony, History, Theory, Sight Reading, and Ear Training as well as the more ordinary courses in practice on the use of the instruments and voice.

Those who are pupils in the department enjoy the work very much and wish here to express their appreciation of the splendid work of their instructors.

\section{Seminary}

TE smallest department of our school, but by far not the least, is the seminary. This department can truly claim the benefit of the age old proverb, "Good goods is done in small packages."

Although the seminary enrollment is small the courses are thorough and handled by able men whose teaching and example can strictly be followed into a deeper and fuller life of Christian service.

We do not feel discouraged on account of the small enrollment since there has been a scarcity of young men and women entering in this type of life service and in all similar departments of other schools there is the same condition.

We do, however, look forward to a decided turn toward vocations of a spiritual nature and a marked growth of this department. We urge that any young person preparing for a great service for the "Master" will take advantage of the opportunities offered here and sit at the feet of those able instructors from whom, we feel has gone out, great powers "Pro Christo et Patria." H. M. 


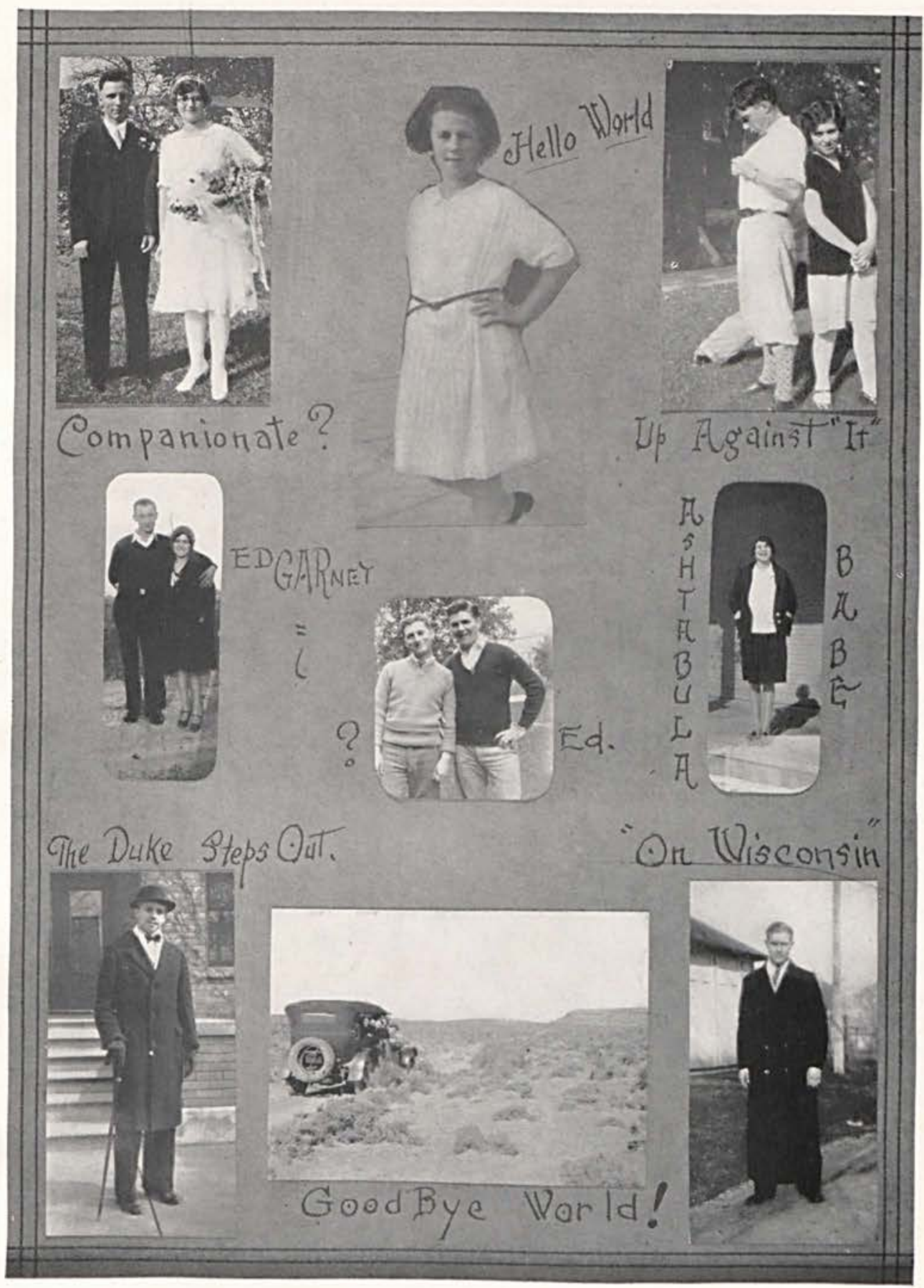




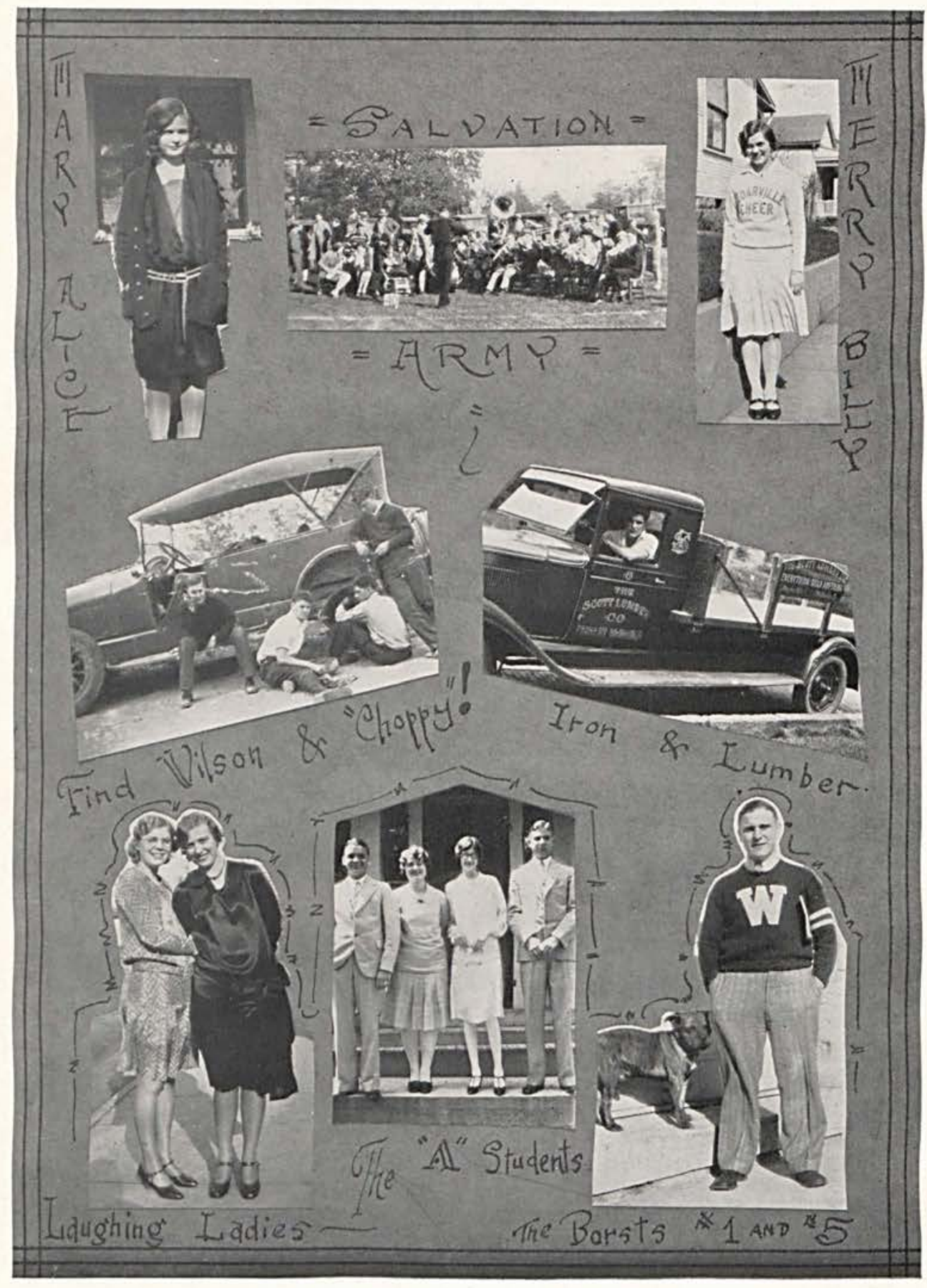




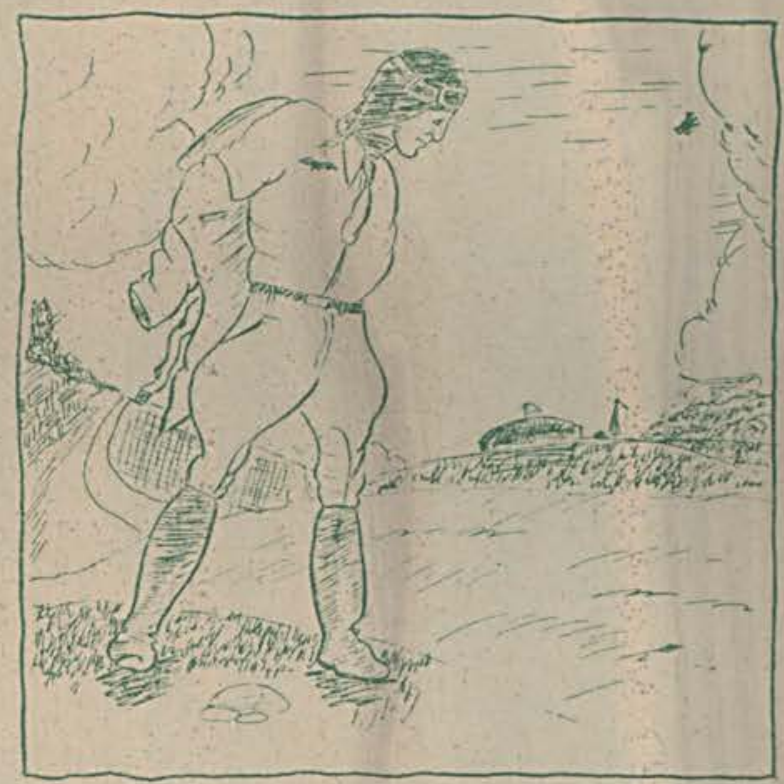

P(t)letics 



\section{Athletics}

Oh, athletics is another fad

We've every kind of ball

Out case has even got so bad

We've some that aren't at all

Such as "Bawl-Babies!" 


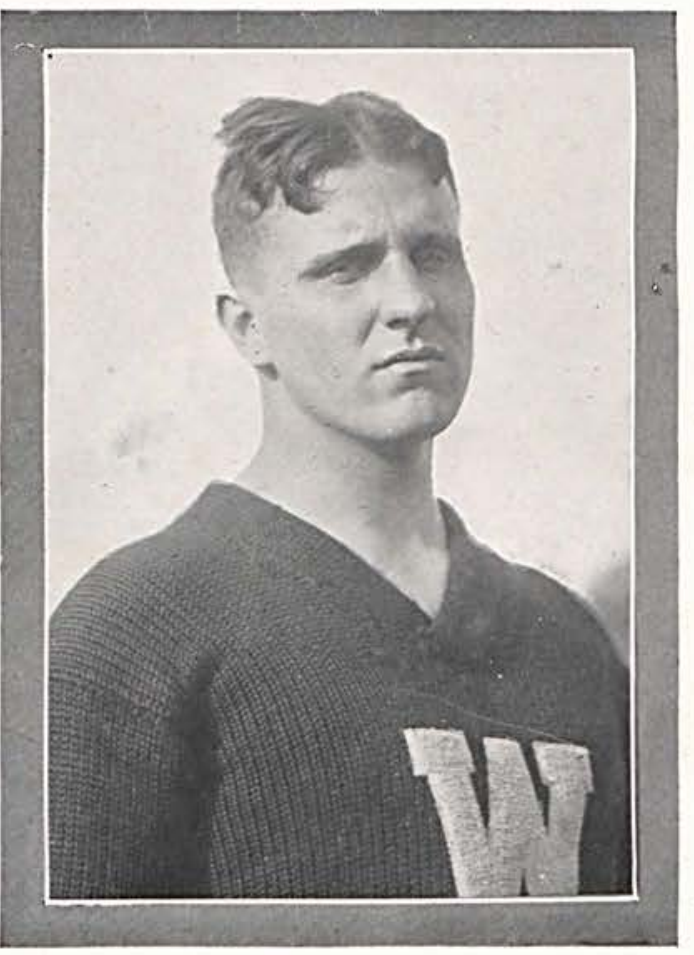

7 HE athletic division of this book we humbly dedicate to Coach Marvin Borst and his achievements at C.C. since 1926, when he came to us from Wittenberg.

When Coach Borst came to Cedarville the athletic equipment was practically a minus quantity. Until the time of Borst the football men were required to buy their own shoes, but that is history now. Cedarville's football togs represent the best that money can buy. There has been three new sets of basketball suits purchased. The baseball men are attired in the same quality of uniforms worn by major leaguers. This is only one of the changes in the "Athletic Reformation" at C.C.

In football our college teams have made quite an advancement. Before '26 no C.C. gridiron team had won more than a single contest during the season's play. That saying was discarded in '27. In '29 the Borstmen held Wilmington to a scoreless tie. The only pigskin tussle between these schools which did not end victorious for the Quakers.

"Yellow Jacket" basketball stock has gained steadily. Before the coming of Borst the court men seldom played over a dozen games a year and several of these with minor independent teams. Now C.C. squads meet the foremost college and university teams of the state and have made an enviable record for a "Small College."

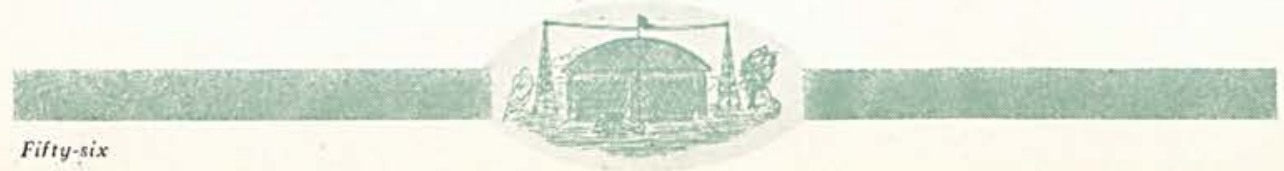





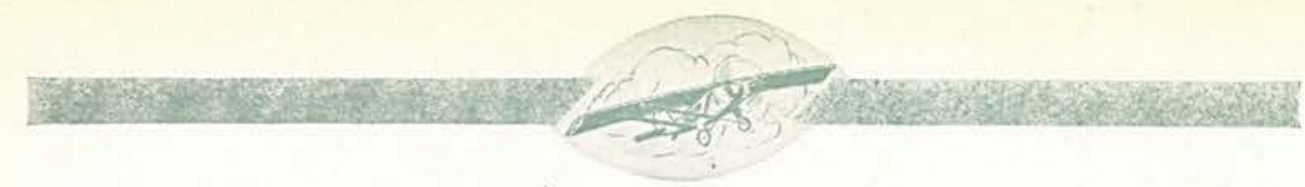

was one of the three night games of the season. Our boys were not used to playing under such conditions. Cincinnati won the game 19 to 0 . But this does not tell half the story for we completely outplayed Cincinnati during the first half. Cincinnati got a couple of lucky breaks later which handed the game to them.

The other night games were with Transylvania and Ashland. Suffice it to say that they beat us by a safe margin. Of course, we must add that they represented the strongest teams in Kentucky and Ohio.

Naturally, we cannot forget that great battle with Wilmington on the "Big Green's" own field. Wilmingon has beaten Cedarville in football, basketball, and baseball for a good many years, but this day our luck changed, and we played a scoreless tie with the far heavier team. And how our boys did fight, for they had a fighting chance. Every Cedarville student that day felt as if this was worth a victory.

When other schools speak of us they sometimes call us "little" Cedarville. We can think of nothing they can mean except the literal meaning "small in size." Our men were outnumbered in reserve squads, certainly. They were, as has been stated, outweighed at every turn. But they played the game "big" and we're proud to say that "little" cannot be applied to their sportsmanship. And after all, that's what counts.

B. T.

FOOTBALL SCORES

$\begin{array}{lrrr}\text { Cedarville } & 6 & \text { Transylvania } & 77 \\ \text { Cedarville } & 0 & \text { U. of Cincinnati } & 19 \\ \text { Cedarville } & 0 & \text { Wilmington } & 0 \\ \text { Cedarville } & 6 & \text { Ohio Northern } & 26 \\ \text { Cedarville } & 0 & \text { Ky. Wesleyan } & 26 \\ \text { Cedarville } & 0 & \text { Rio Grande } & 6 \\ \text { Cedarville } & 0 & \text { Ashland } & 45 \\ \text { Cedarville } & 14 & \text { Wilmington } & 33\end{array}$




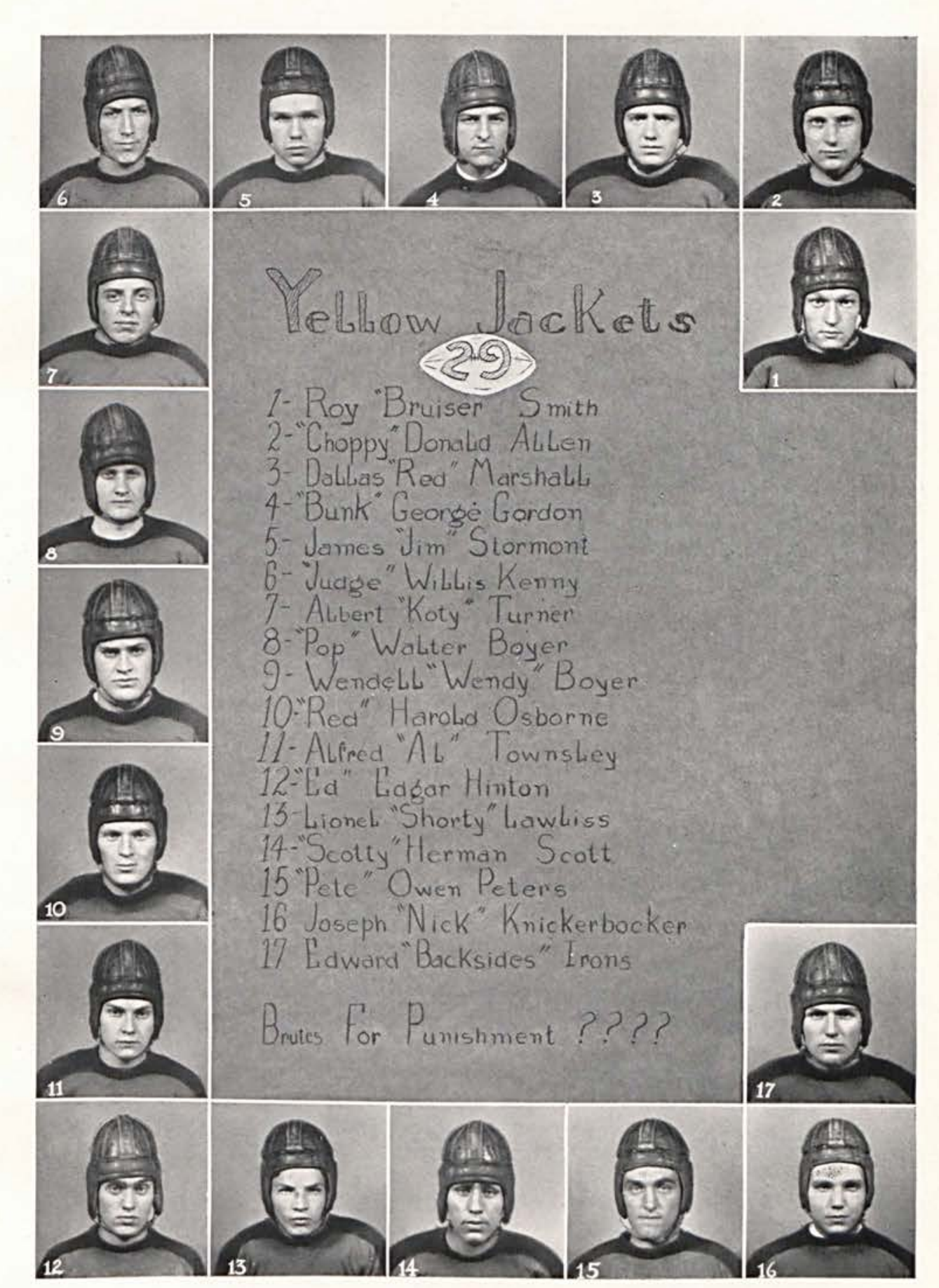




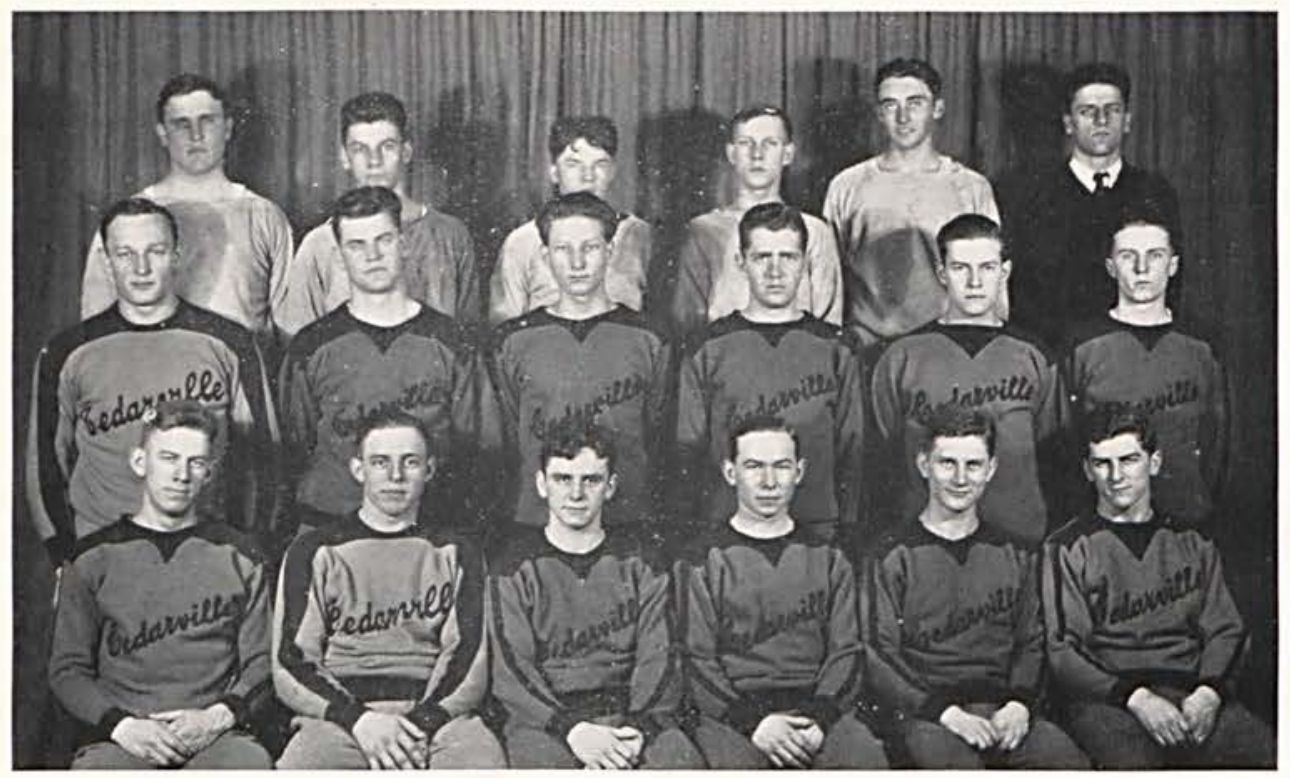

Back row: Coach Borst, Baker. Lawliss, Richards, Spencer, Mgr. Collins. Middle row: Smith, Boyer, Best, Marshall, Townsley, Wilson.

First row: Garlough. Turncr, Rife, Kinnison, Allen, Gordon.

\section{Basketball Review of '29:'30}

T $\mathrm{N}$ recent years, basketball has been Cedarville's sport forte. Practically a veteran team, experienced in playing together, turned out for the first practice this year. Had this group continued the prospects would have turned out as they looked at first-fine. But before the season was finished, the veteran group was broken. All credit is due, however, to those who filled their places, and were excellent sports at being second choice. We are heartily appreciative of the fine work they did for us. Most of these were members of that promising group of Freshies which appeared at Borst's first "call for men."

On December fourth the boys opened the season with a decisive victory over the boys from Antioch. However, after starting out on the right foot, they tripped and fell on the wrong side of the winning column for the next four games. But two of these games were with the powerful Cincinnati University and St. Xavier teams.

They proved, however, that though they were temporarily "down" they

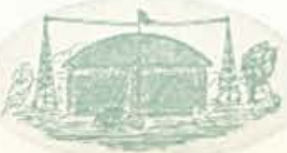





\section{SCORES}

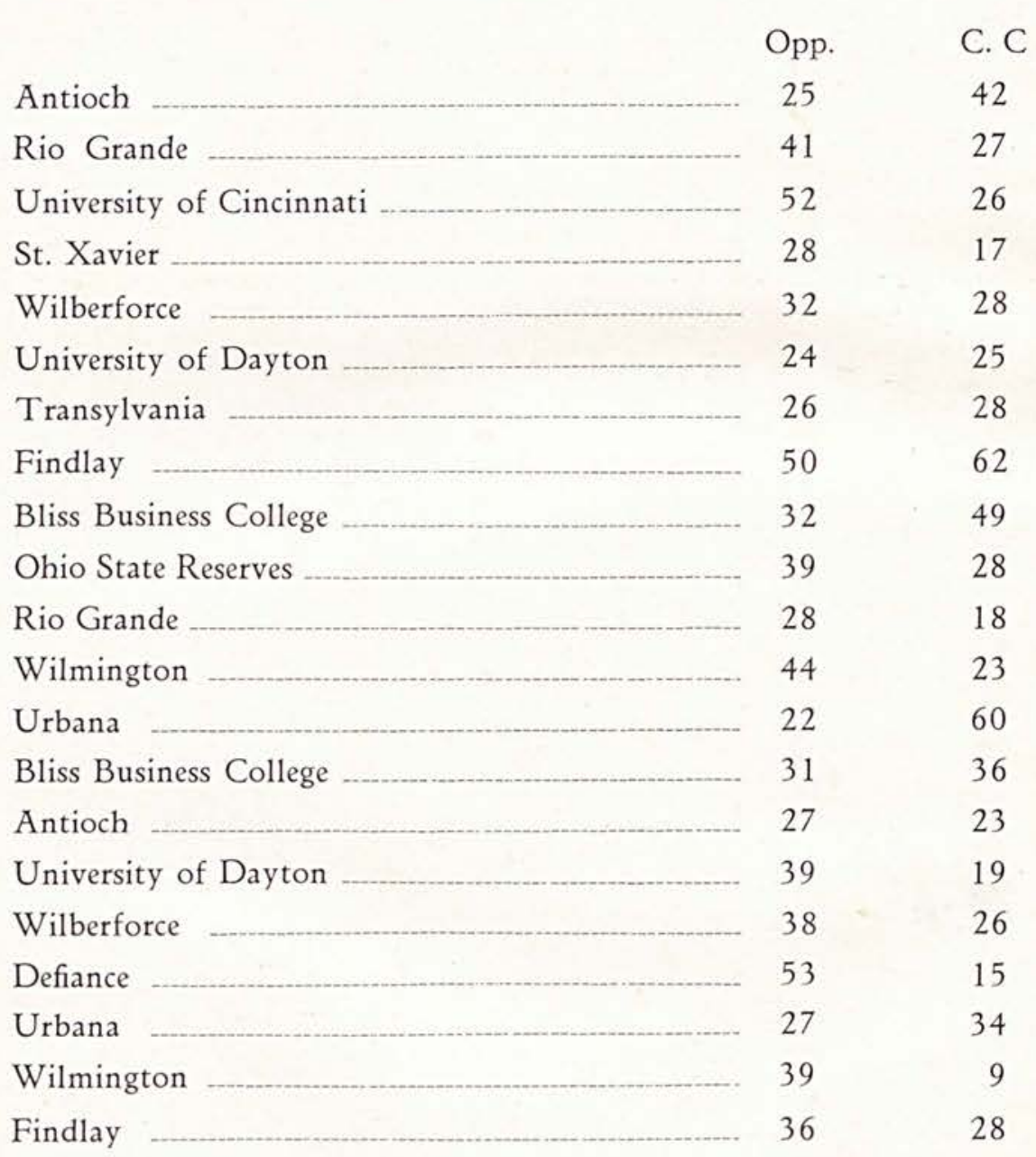




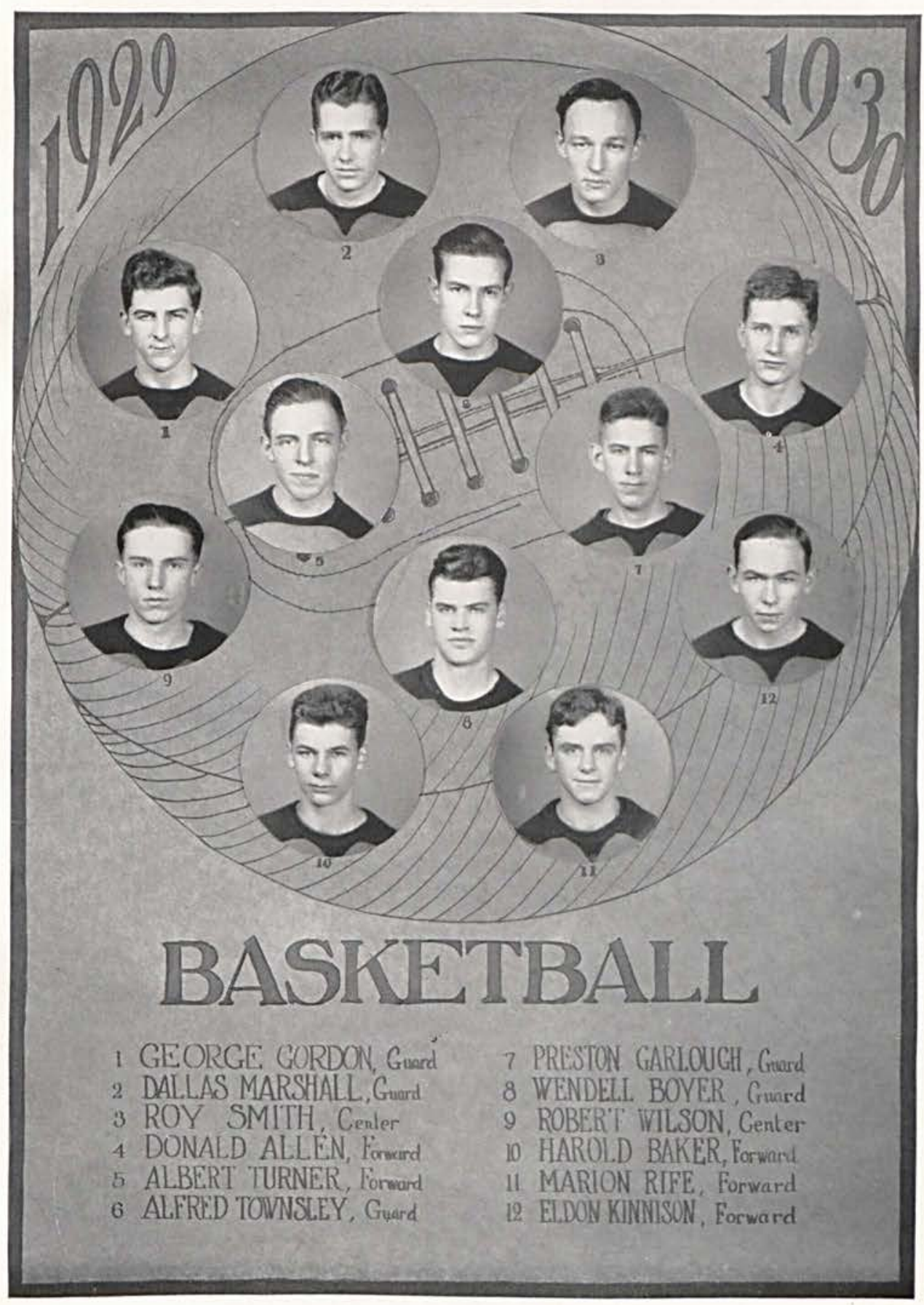




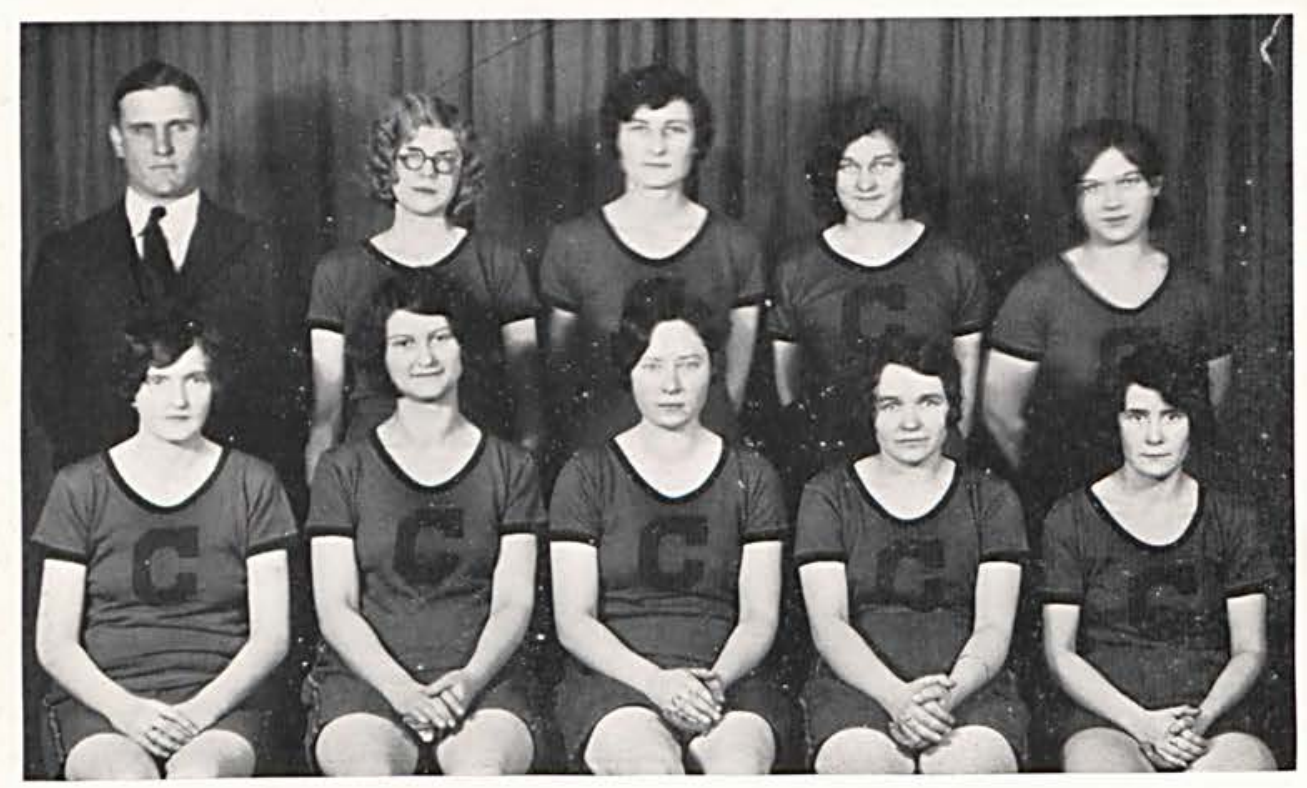

Standing: Coach Borst, Marshall, Carle, Smith, Rumbaugh. Sitting: Merriman, Kirby, Tanncr, Auld, Swaby.

\section{Girls' Basketball}

THE girls had a very successful season this year, going down in defeat but twice. An exceptionally classy center, accurate forwards, and a trio of fine defensive players made up a hard half-dozen.

As for personal mention we start with Captain Tanner, also captain last year, who has led her team to victory in thirteen out of eighteen contests in the last two years. A very good record and we sure will miss her. The other two Seniors will also leave quite a gap to fill next year, Raisenen and Kirby, two stellar guards.

\section{THE PLAYERS}

TANNER - forward. Our captain. Some shot.

SMITH - center. Oh, those lengthy arms. RUMBAUGH-guard. We don't mean maybe.

KIRBY - guard. Between me and Rumbaugh.
SWABY - inter. Pep persenified and those eyes, Oh, Boy,

RAISENEN-guard. $U p$ in the air.

MARSHALL — guard. Our "blondy."

MERRIMAN - forward. Quick and snappy.

ALLD - forward. Little but mighty.

CARLE-manager. The patience of Job bas she.
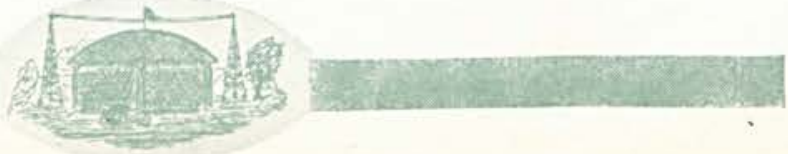


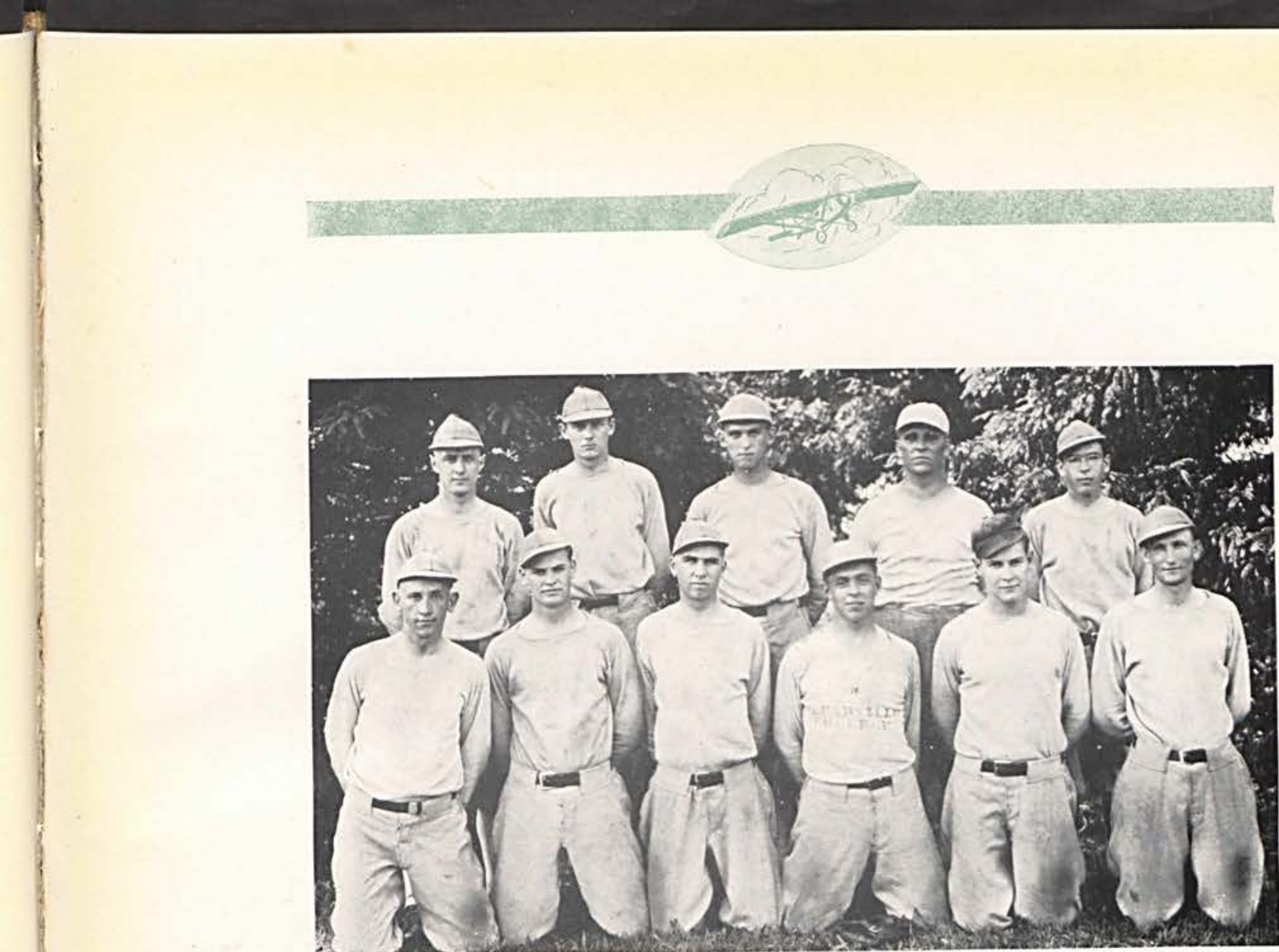

Back row: Tanner, Armstrong, Peters, Coach Borst. W. Turner.

Kneeling: Scott, Wen. Boyer, B. Turner, A. Turner. Townsley, Lyon.

\section{Baseball Review of '29}

T the early years of the college's history, Cedarville was baseball noted. They even approached championship. We do not claim quite so much honor, but we want our share, at least. Cedarville's baseball team last year made a good showing and played creditable games.

We must admit at the outset, that while there was some good baseball played by our team last season, yet there were also some mediocre games to its credit. We had some tough breaks, the weather man had a prejudice against our practicing, and there were some minor and major injuries to baseball men. All of these things contributed to the mediocre side.

Two games especially, were occasions of downfalls, when it seemed to us, that luck was just not with us.

The peak of the season as far as success goes came with the game at Muskingum. There we beat a team which up to that point had won every game of the season. The score was 4 to 3 .

We lost two heartbreakers to Antioch, one battle going to ten innings, with our team merely nosed out.

The queerest game of the season was played with Dayton at Dayton. It
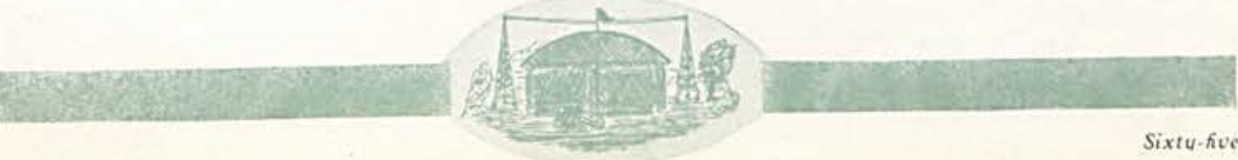
was a freak in every respect. This game started in a downpour of rain and the downpour did not stop until nine innings were over. At the beginning of the fifth inning the water measured one foot at home plate. The team was not equipped with bathing suits, nor used to leaded feet, so we list. It is a singular fact, that in the return game with Dayton at Cedarville only two innings could be played because of rain. Anyhow, we weren't beaten.

This year a new league was formed by the coaches of four schools with cur coach at the head. The schools were Cedarville, Antioch. Wilmington, and Wilberforce. The league was therefore called the C. A. W. W. League. This added to interest as well as some other phases.

Other games which we played were two with Wittenberg and one with Defiance, the latter being the occasion of our second trip of some distance away. Each team in the League had three games with each other team so we were well supplied with games both at home and "abroad."

At the time of this writing, it looks as if Cedarville might have a real ball team this year. A number of the regulars are back and also a most promising group of new material. Our hopes are high. And perhaps the next Cedrus will show more games in the winning column.

B. T.

\section{A Toast by Coach Borst}

$\mathrm{N}$

greater tribute can be paid to our athletics at Cedarville than to say that they are clean, fair, and free from all scandal. When one considers the type of boys that engage in athletics at Cedarville College, free from all flattering inducements and bribes, one can readily see why we have the "TRUE SPORTS." Our boys play the game because they like it not because they are paid to do it, and I don't know how many times I have heard this expression, "A fine bunch of boys, where do you find them?

Athletics will be better in all branches during the coming seasons, especially football and baseball. At the present writing it looks like we will have a fine bunch of Freshmen to select from when September rolls around.

Our boys have not always won, as our records show, but at least they have always given their best. On every occasion they have been true Sportsmen, taking defeat rather than gain through unfair methods. To these men goes the best that C.C. has. We are very thankful to all those who help make them the kind of boys we are proud of. lege."

Let us dedicate a new Aim, "Bigger and Better Sports at Cedarville Col- 



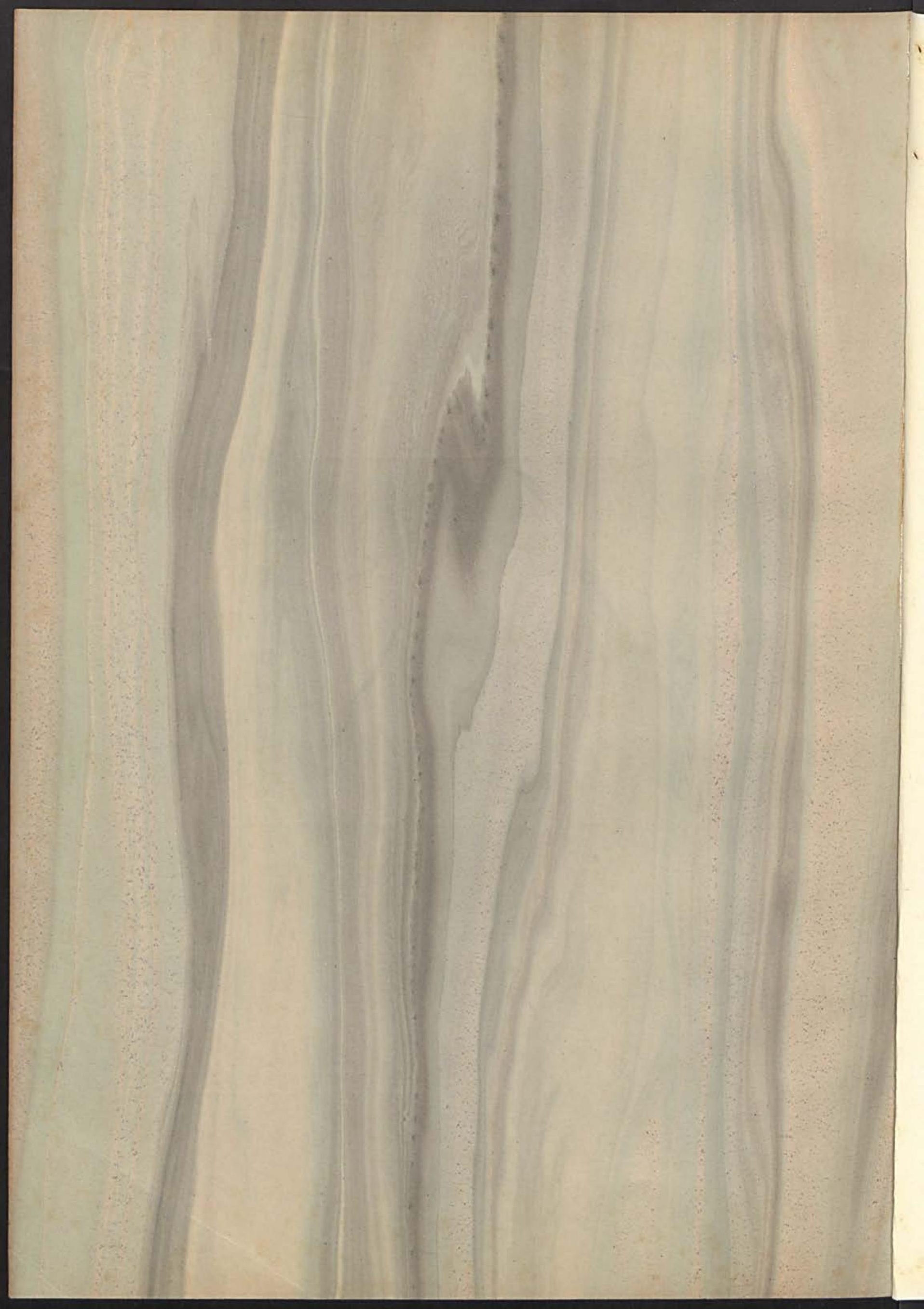

। 


\section{Organizations}

Oh, organ'zation's such a word I can't begin to spell it.

And Cedarville's are such a lot I can't begin to tell it.

Just look!

Aren't we the proverbial berties? 



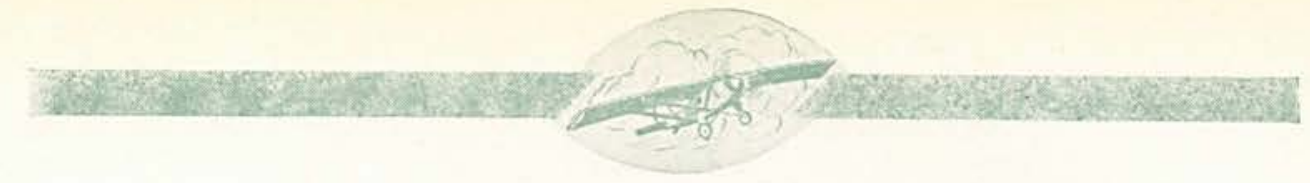

at any time from this book we will feel that our labors have not been in vain.

There are a few persons outside of the regular college routine that have helped make this book what it is: to them we extend our sincerest gratitude and will now mention them personally.

Mr. Robert Thompson, who we all learned to admire during his three years at Cedarville College, helped with the Art work, drawing the pages for the division pages and the border views. Mr. Elmer Jurkat, the genius, gave very valuable aid in arranging the snapshot pages. He also helped with the Diary in his incomparable witty manner. It seems almost a shame not to give personal mention to our own Art Editor, who labored so hard in preparing this book. Marion will come in for his share of the glory in the next few years which will be well deserved.

To next years staff we will all our cares, griefs, and woes. We hope they can far surpass this example. If there is anything we can help them do at any time we will only be more than glad to do it.

Dallas Marshall

Editor-in-Chief

Frances McChesney

Assistant Editor

Paul Tanner Business Manager

Marion Hostetler Art Editor

Carmen Frazier Society Editress

Harry Pickering

Professor R. M. Borst rtising Manager

Brenton Turner Faculty Adviser

Wilda Auld

Robert Wilson

Mary Ruth Wham Girls Athletic Editress

Jean Morton Humor Editor

Lucile Tanner

Wilma Curry Music Editress Snapshot Editress Snapshot Editress Diary Editress
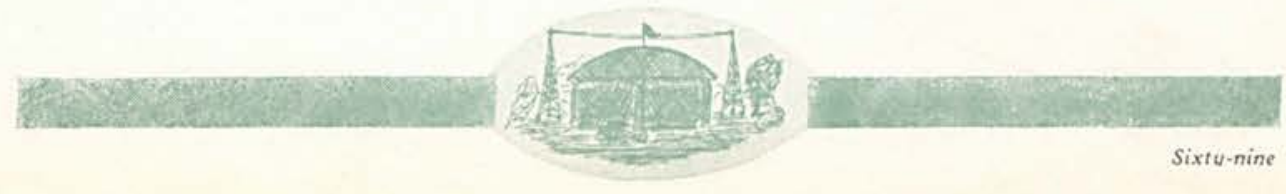


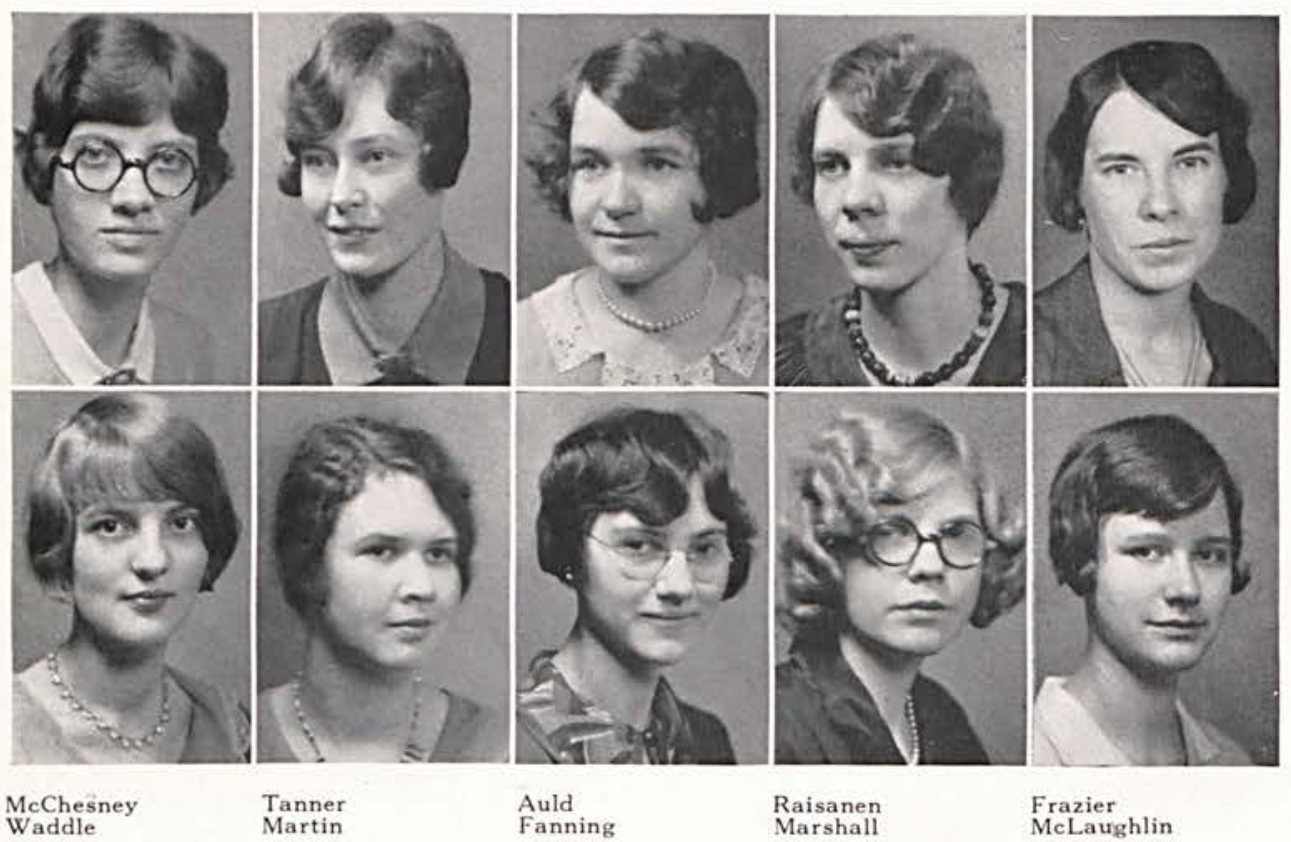

\section{Young Women's Christian Association}

Frances McChesney President

Lucile Tanner Vice President

Wilda Auld Secretary and Treasurer

Hilma Raisenen Social Chairman

Carmen Frazier Program Chairman

Martha Waddle Social Service

Gertrude Martin Publicity Chairman

Dortha Fanning

World Fellowship

Ruth Marshall Industrial Chairman

Eloise McLaughlin Finance Chairman

Miss Dorthy Angevine Faculty Adviser

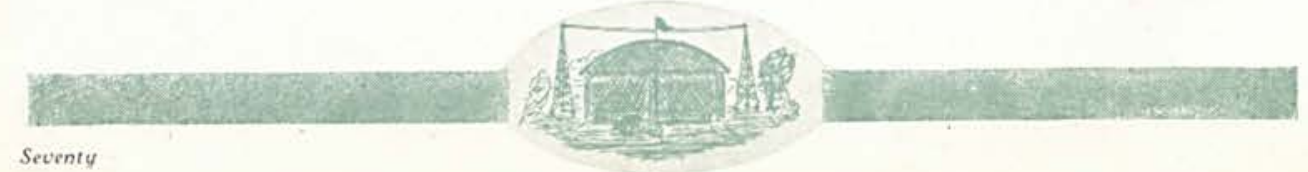





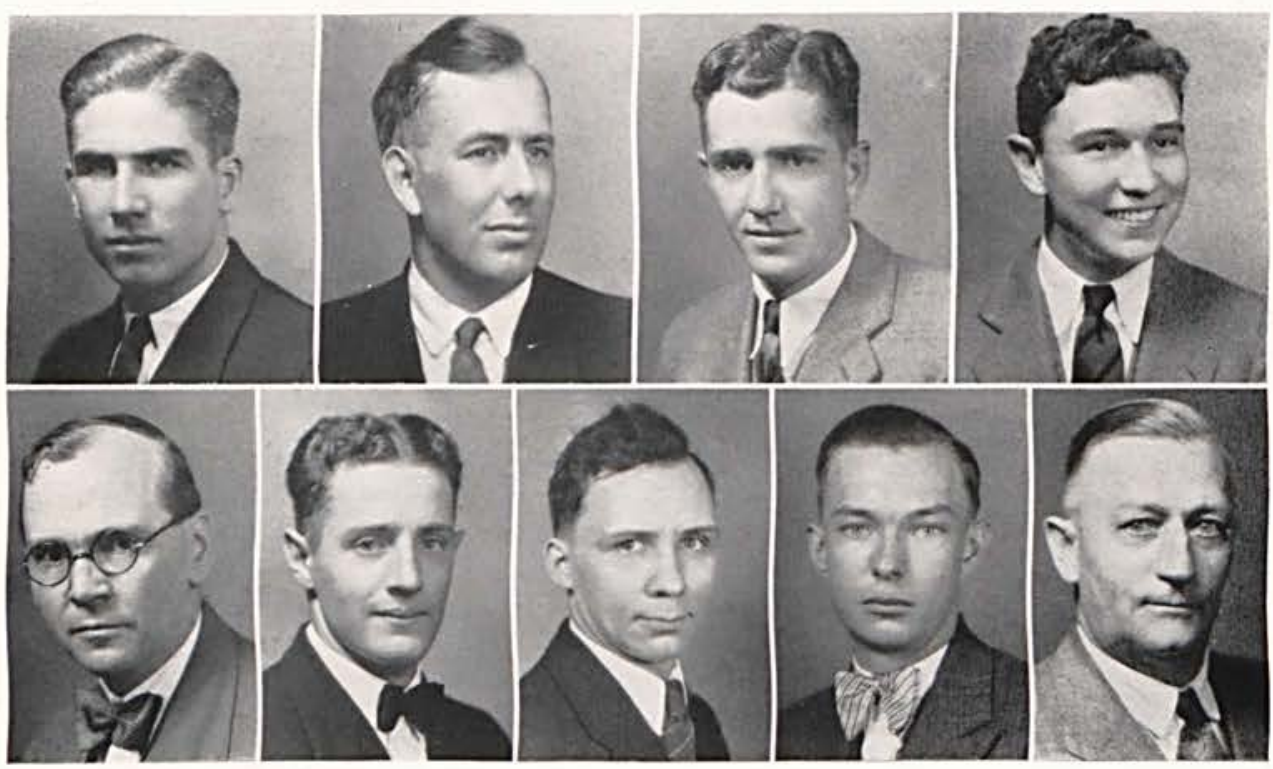

\section{Young Men's Christian Association}

Brenton Turner
Newton Mantle
Dallas Marshall
Harry Pickering
Prof. A. J. Hostetler
Paul Tanner
Frank Graham
Howard Flater
Prof. C. W. Stecle

THE Y.M.C.A. is a very active organization of the college, having most of the young men of the college enrolled and regular attendants at the meetings which are held every Wednesday morning at the regular chapel hour. This year the men were given the privilege of hearing ministers of the town and nearby cities in the special talks. Some men of other lines of activity

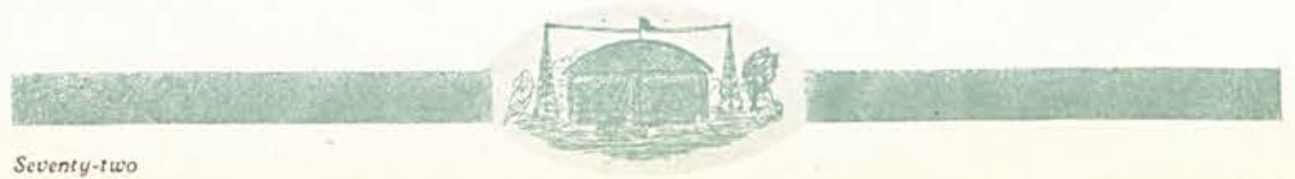




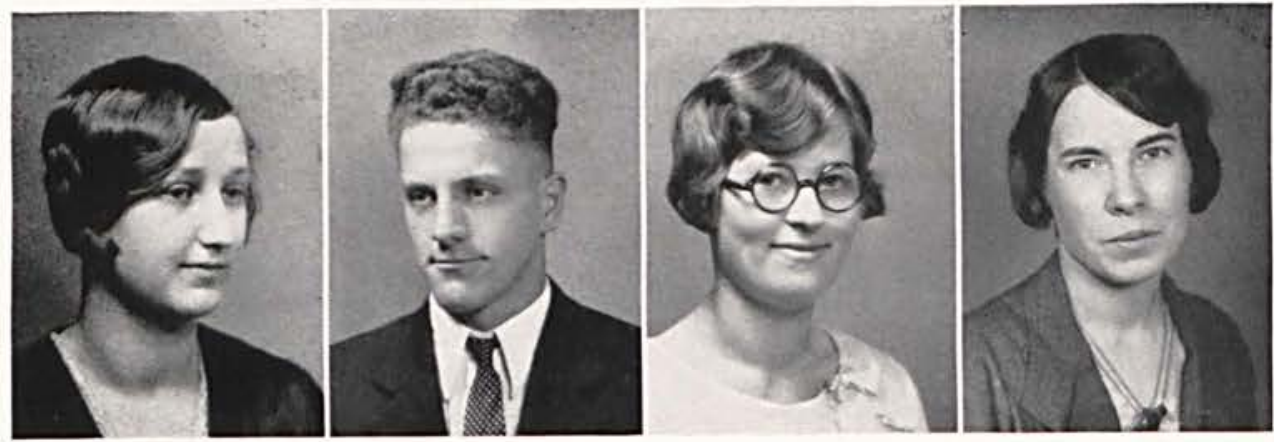

\section{Philosophic Literary Society}

Lillias Ford

Robert Collins

Betty Graham

Carmen Frazier
President

Vice-President

Secretary

Treasurer

EALLY, is there need of a great many words? Those of us who have enjoyed the delight of being full fledged members, need we be reminded of the ne'er-to-be-forgotten hours spent in the Club waiting room on Philosophic nights? As for those who have unintentionally or otherwise deprived themselves of the pleasure-well, they are out of luck.

That may sound a bit crusty, and we are not a crusty lot. We are simply bubbling over with enthusiasm and cannot understand why some hesitate. Such

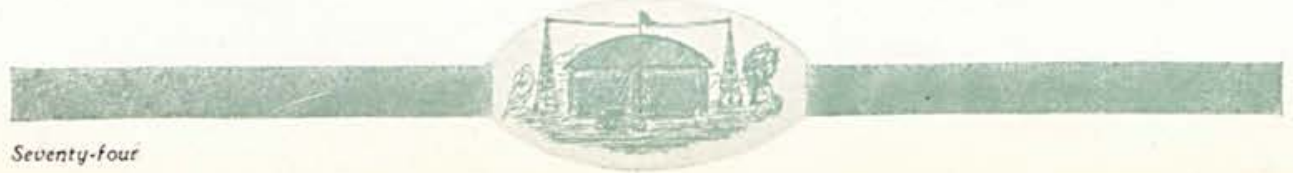




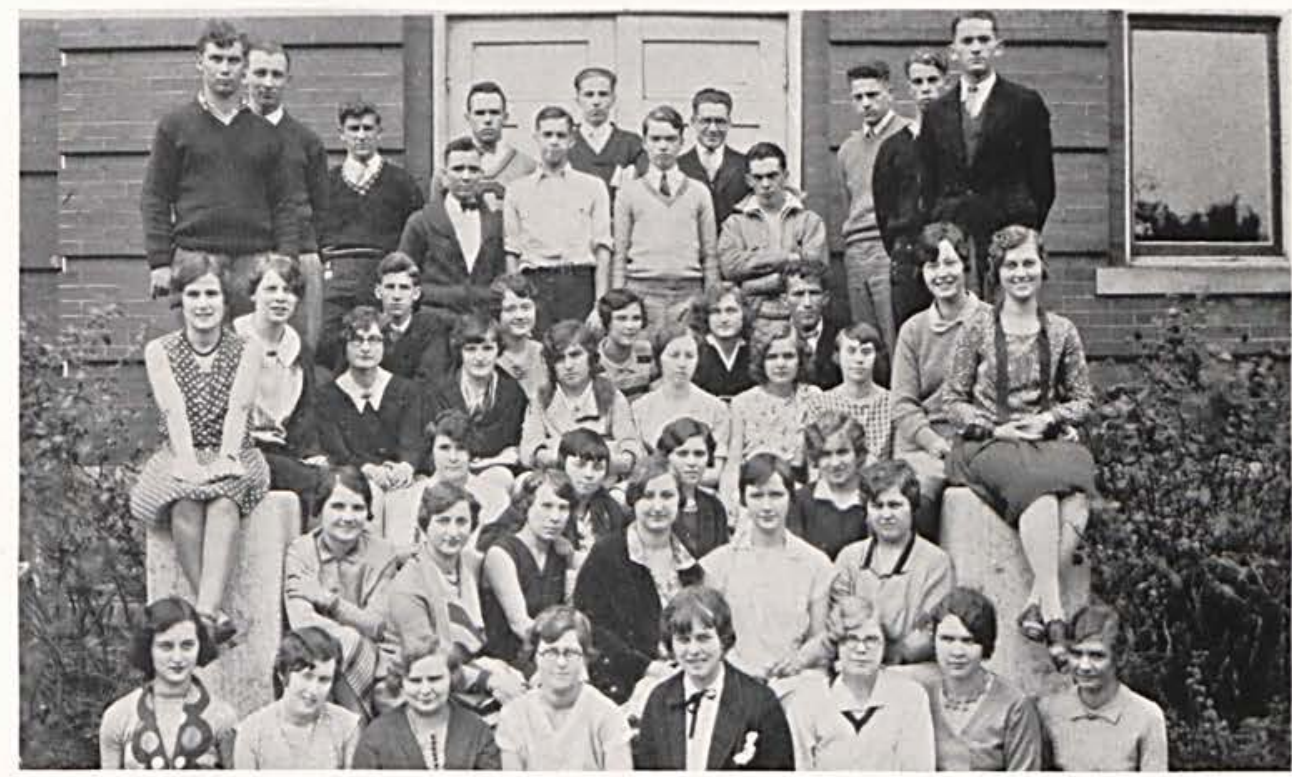

wholesome entertainment, such feeds, such grand fellowship is not found in any other college activity.

We are thirty-five strong and our motto is "Perpetual Always."

Imagine putting on some comfortable clothing and sauntering down to the College Club waiting room on Philosophic nights. Imagine hanging 'round the faithful little stove for a nice chat before the rap of the gavel. Imagine the sacred quiet of the Devotional Service. Imagine singing old time songs-your choice (if you please). Imagine settling one's self to listen to original ideas delivered in rare form; to quaint readings and impersonations; to enjoy instrumental and vocal solos; the "latest song hits" by the peppiest little orchestra in town. And then imagine all the time sniffing, sniffing sizzling hamburgers and steaming coffee, or something else as good.

We are a happy lot. Well fed spiritually, intellectually and physically: and even in these strenuous times we are out of debt and have a bank account.

$$
\text { C. F. }
$$
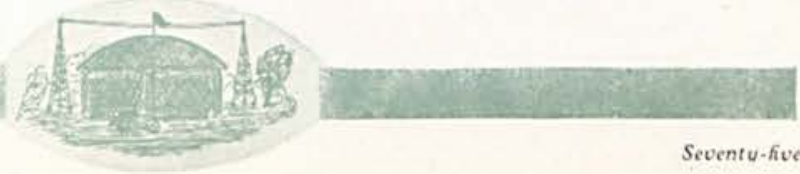


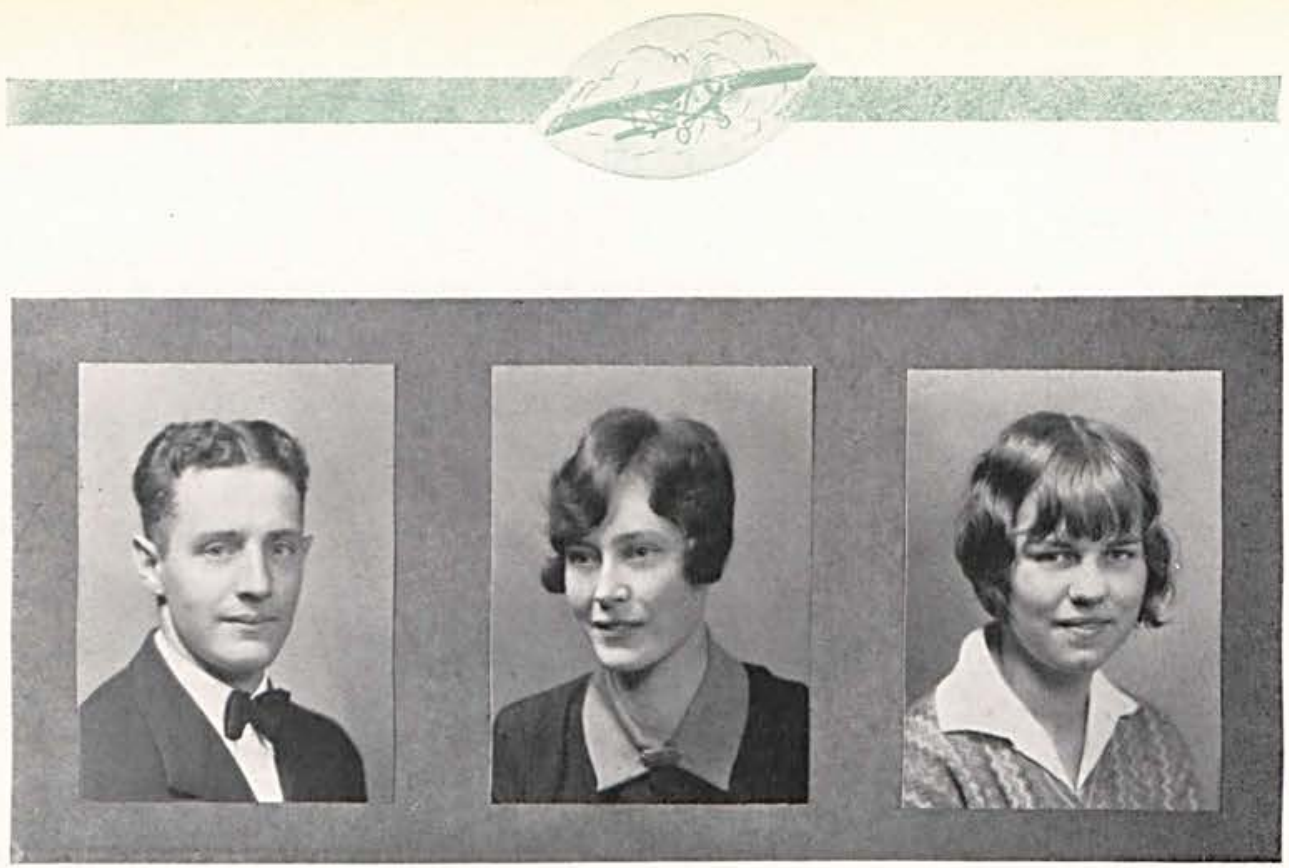

\section{Student Body}

Paul Tanner

President

Lucile Tanner Secretary and Treasurer

Wilma Curry Cheer Leader

M

ANY things are necessary for the maintenance of a college, first of all a college must have a group of students.

In spite of the many criticisms, one who really knows our students will realize that after all there are still some young people whose ideals are high and their visions unclouded. A process of natural selection leaves at Cedarville only such men and women who are willing to sacrifice some of the pleasures of life in order that they may enjoy that full happiness that comes with the knowledge of a task well done.

You will find loyalty in Cedarville College. The students are loyal to fellow students, professors, and above all their Alma Mater. Since there is also a spirit of friendliness and brotherhood, no one needs to get lonesome at Cedarville.

But we must not forget our studies. Under the leadership of a faithful and capable faculty we develop to the best of our abilities. Music plays a great part with many of the students. The newly organized band has been the life of the athletic contests. Our wish is, that it may continue to grow in passing years.

$$
\text { P. P. T. }
$$

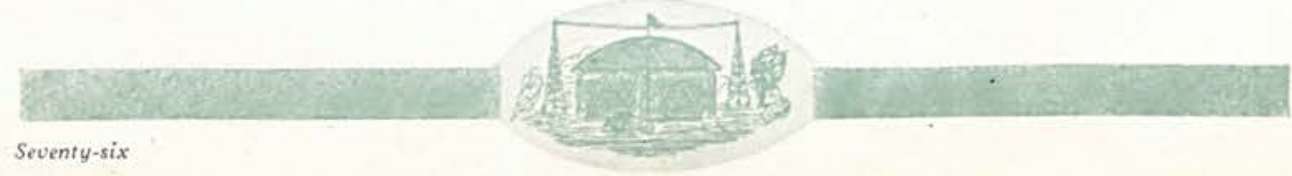



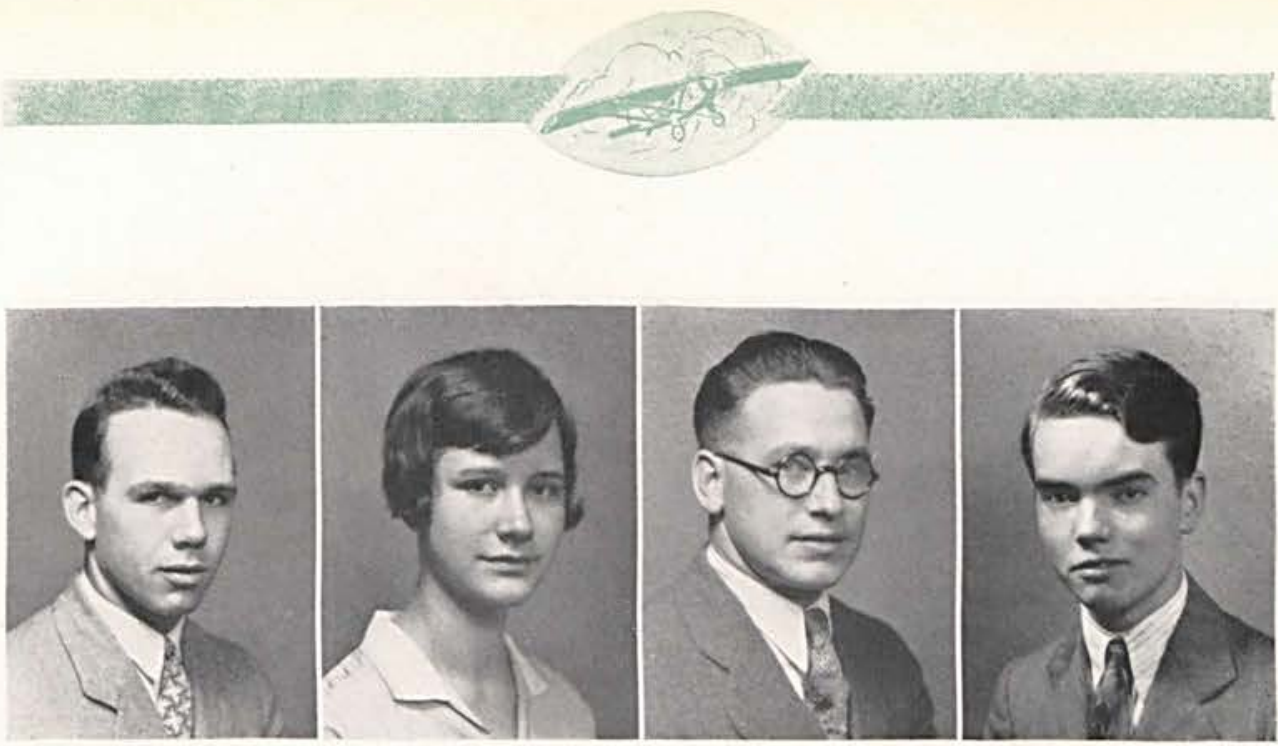

J. Stormont, E. McL aughlin, H. Main, M. Hostetler

\section{Cedar Needles}

INCE all colleges have a paper issued at least once a month it was only fitting and proper that Cedarville should keep abreast the times and do likewise. Realizing the amount of good that can be received from a publication of this kind, some of the interested students met and pledged themselves to the duty of renewing "Cedar Needles." Although this was started rather late in the school year it has become quite promising.

It takes so much money to finance a large publication and since money is a minus quantity with most of us, we decided to start "Cedar Needles" humbly but not uninterestingly. We feel sure that all who have seen this paper will agree with us on this score.

As the old proverb runs "Great oaks from tiny acorns grow," so let it be with Cedar Needles. That from a small humble beginning it will grow to become a very great and very necessary part not only of the college but of each of us who are loyal to our Alma Mater.

H. M.

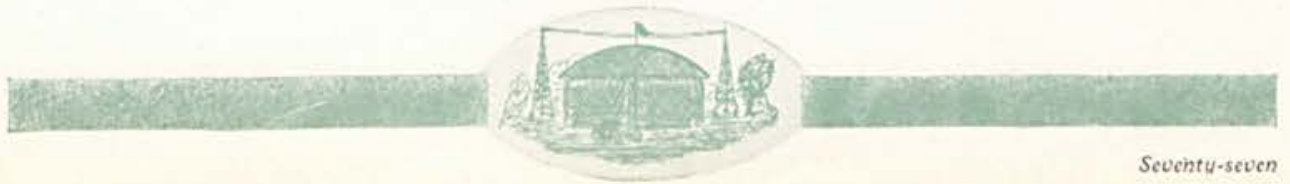




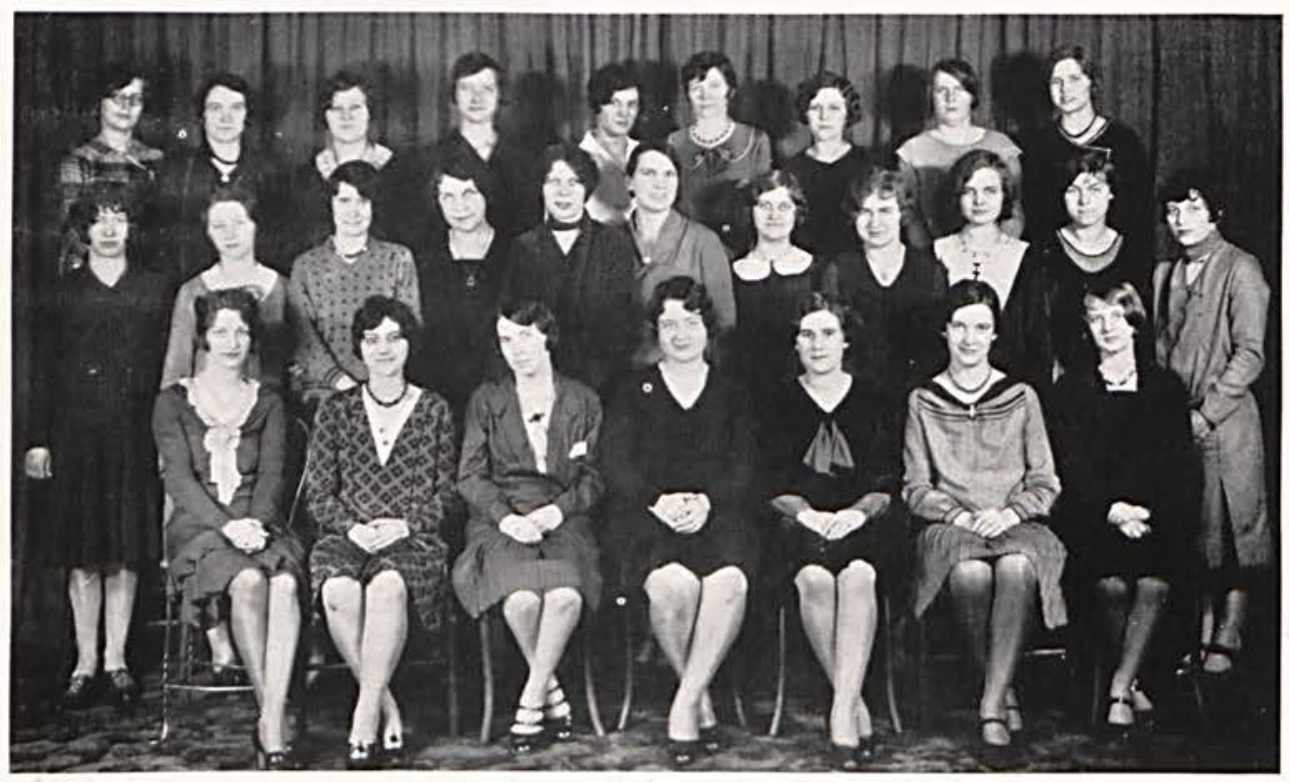

\section{Girls' Glee Club}

$\mathrm{W}$

ITH most of our old members back and several talented new ones, our glee club has been doing splendid work this year. We have thoroughly en joyed the variety of songs which Miss Berkley, our director, has so well selected. We sing lullabies, waltzes, negro spirituals, cantatas and sacred numbers with equal pleasure.

Our concert was well attended and applauded. The various chorus numbers, solos, duets, quartets and readings afforded a most worth-while entertainment. The compliments we have received on our improvement in ensemble work have encouraged us to try to do still better.

We, also, sang at the college service held in the First Presbyterian Church. We have appeared before the student body several times. We are planning to give concerts in neighboring towns.

Now, the boys are starting a glee club. Although we have quite a start on them, we have a hunch we will have to work to keep ahead, once they get started. But we can do it.

L. L. S.
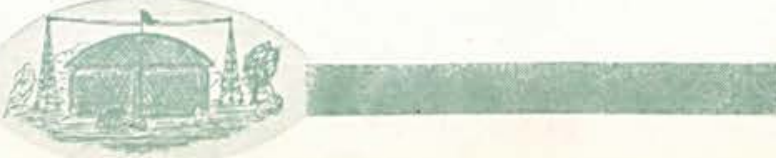



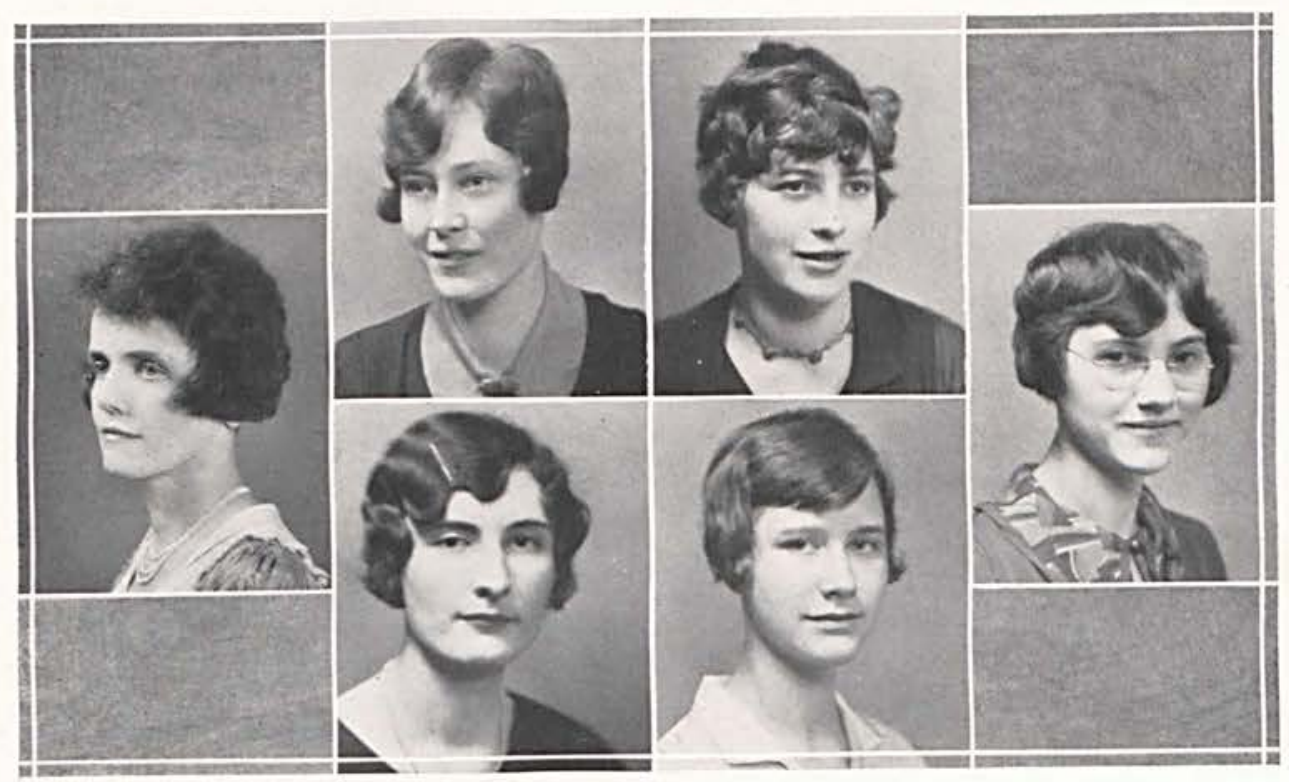

Angevine, Tanner, Roseberry, Fanning Carle, McLaughlin

\section{Girls' Student Council}

THE purpose of the Girls' Council is to aid the Dean of Women in making college life interesting and in solving the problems of the non-resident girls. The Council consists of representatives of the three upper classes and the Normal Department.

The members are: Miss Dorothy Angevine, Dean of Women: Miss Mildred Carle. Junior representative: Miss Marian Roseberry, Normal Department; Miss Eloise McLaughlin. Sophomore Class: Miss Dorothy Fanning and Miss Lucile Tanner of the Senior Class.
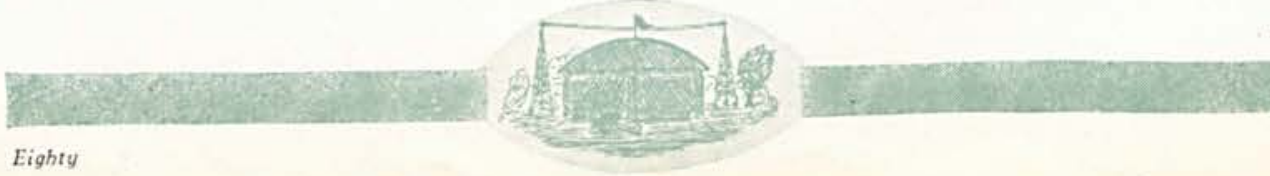



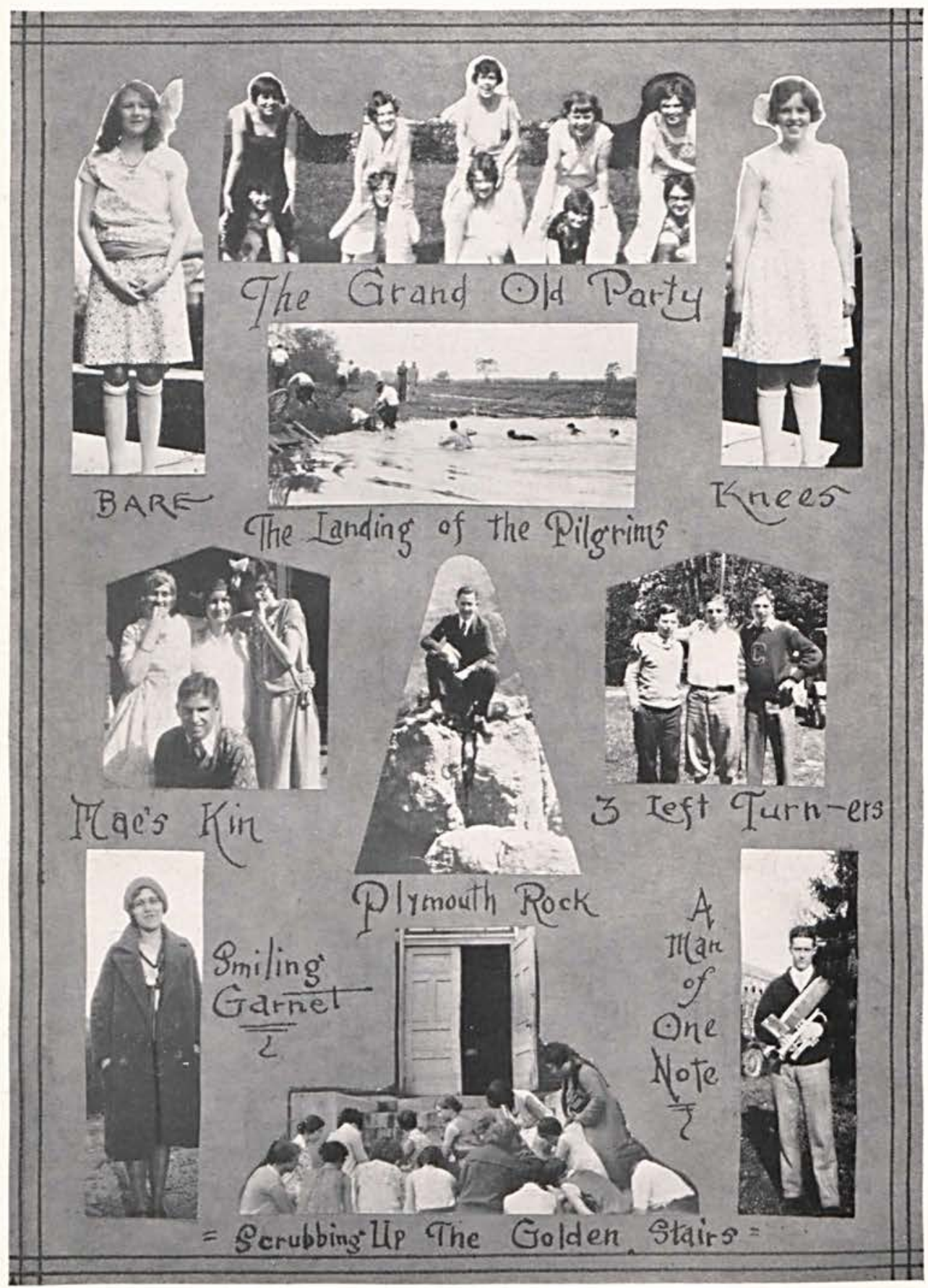




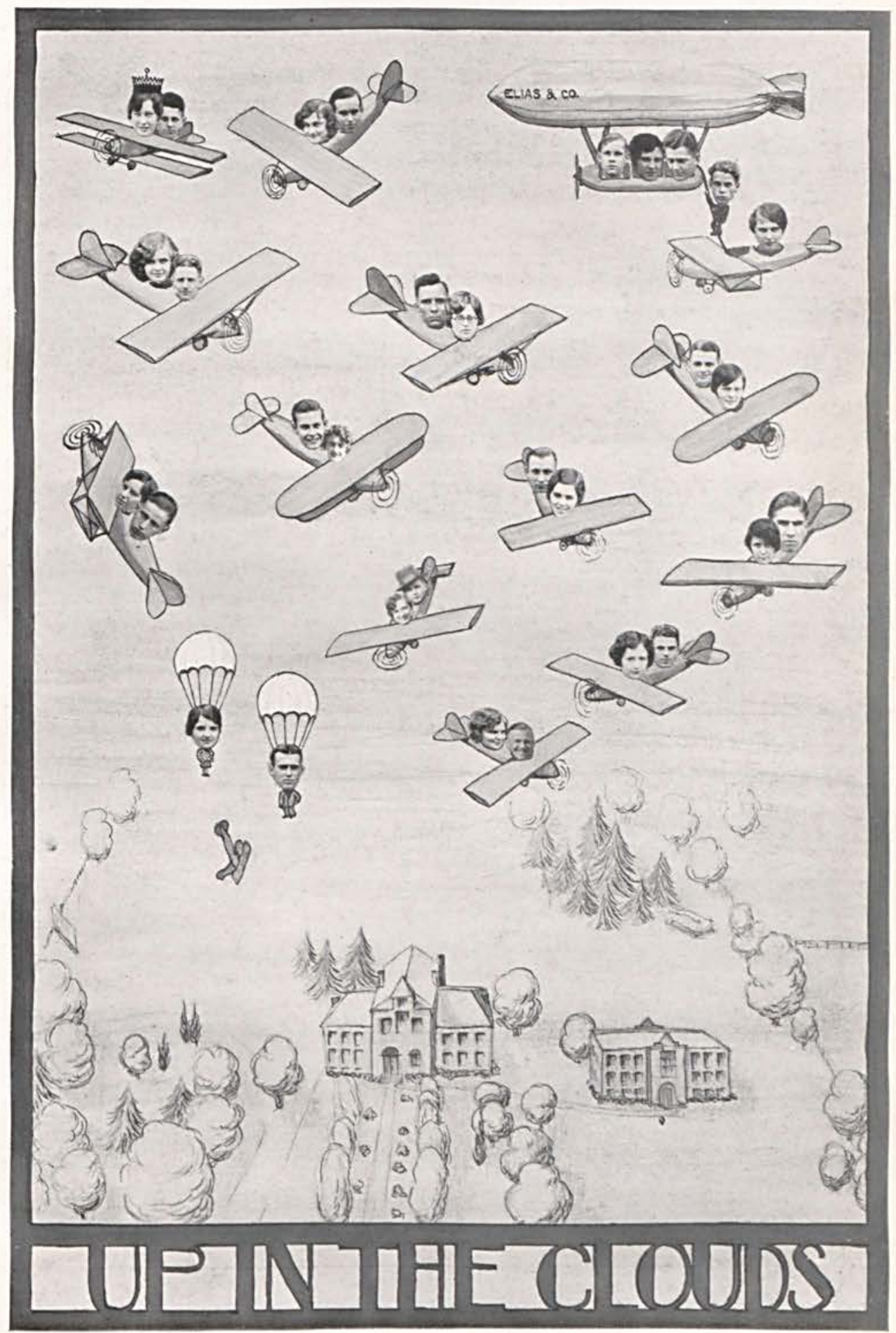




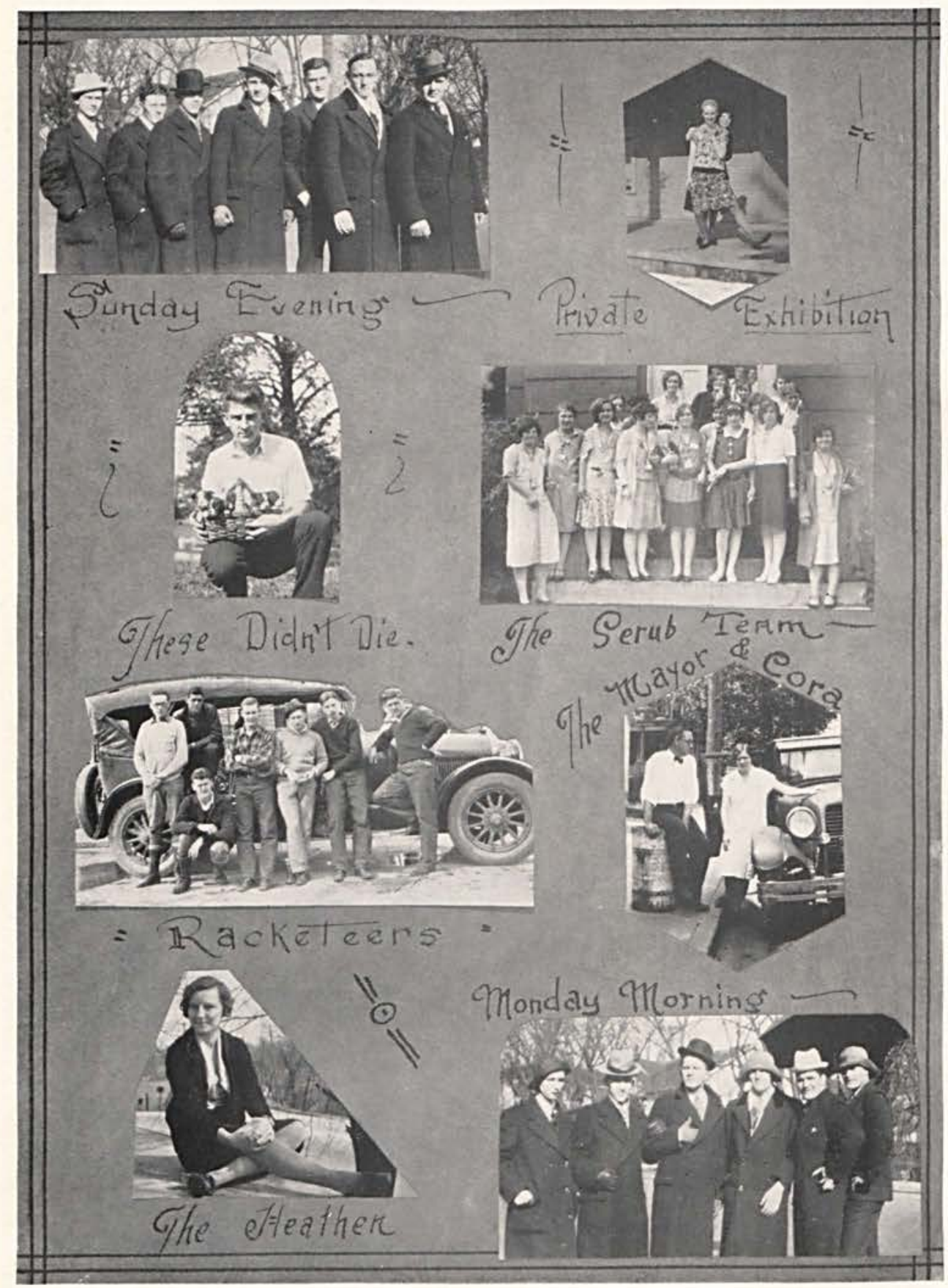





\section{Activities}

Oh, when there's nothing else to do

We conjure up a play.

Or some activity like that,

For which you have to pay.

And we get either the money or the tomatoes. 

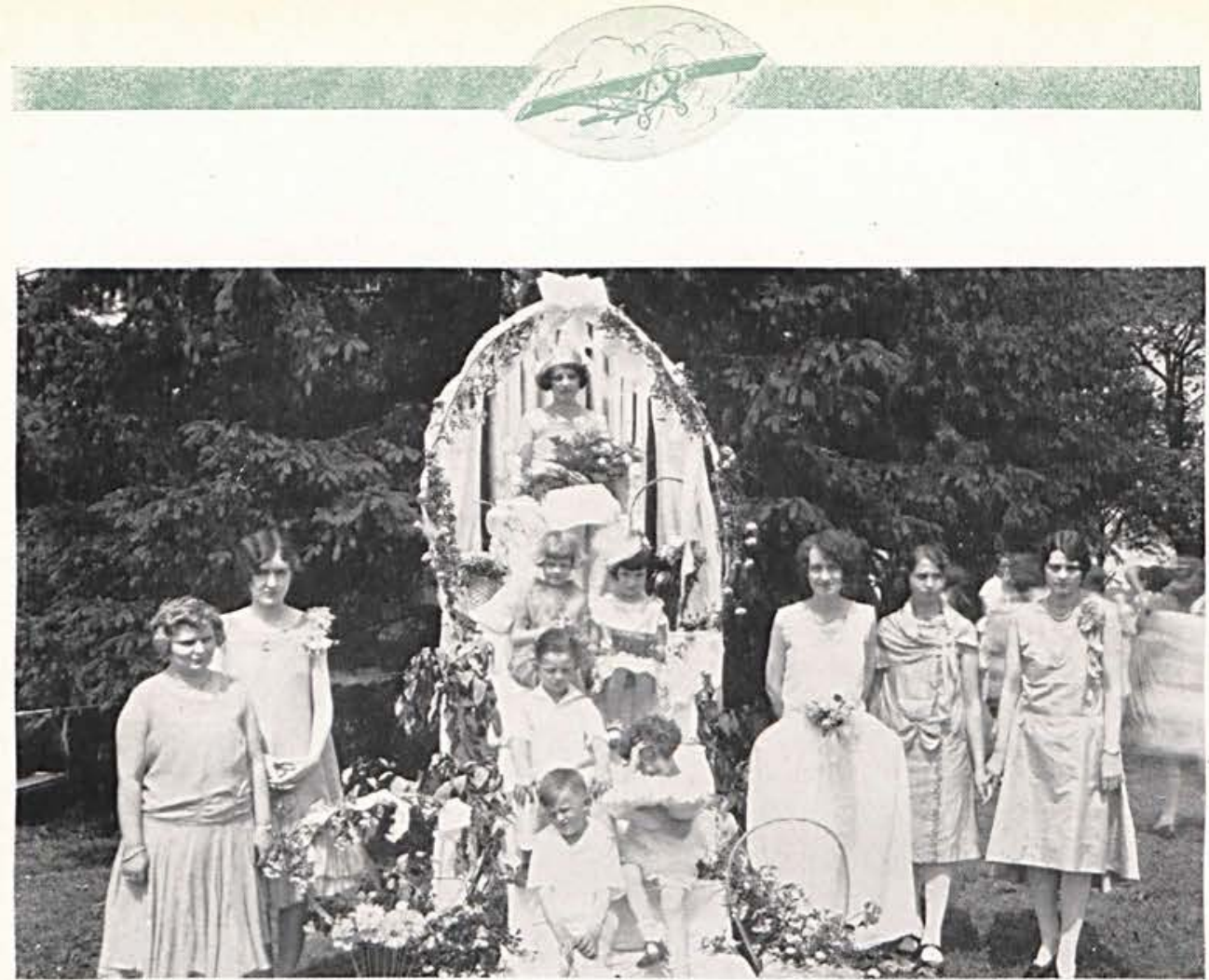

\section{Queen for a Day}

HAIL:

She in her pomp and glory

Sits upon her snowy throne.

As did those in fabled story

On like platforms of their own.

See! Her fresh and glowing beauty

Makes the world around her fair.

Make obiesance. Shall less duty

Be her privilege who sits there?

Then bend low.

For she's Queen of the May For a day.

\section{HARK!}

The fairy trump is blowing.

Come her courtiers one by one.

See how happily they're going

Glad to claim her for their own.

Who would not be happy? Sure not

He who owns her for his Queen;

For his is the joy of springtime;

All the May world is his scene.

Then bend low.

She is Queen of the May

$$
\text { For a day. }
$$

\section{RISE!}

She rises. She is royal.

Let her regal splendor reign.

Let her leiges all be loyal.

Let no subject sorrow feign.

Hers may be a passing kingdom:

Hers may be mere temporal power:

Matters not. The world will claim her

Queen of Beauty for an hour.

What is better?

For she's Queen of the May

For a day.

$$
\text { F. M. }
$$




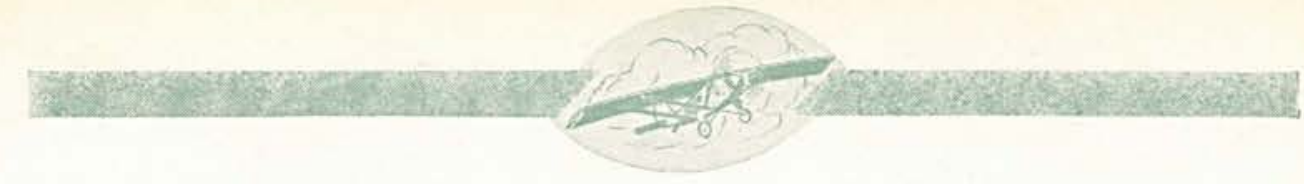

\section{Cedar Day 1929}

THE Cedar Day exercises of 1929 presented quite a gala spectacle. Everything worked out to perfection, with a perfect summer day, a large crowd, and a well prepared program, one would expect something out of the ordinary.

Miss Margaret Chandler was our Queen for a day, and what a typical queen was she.

The program was carried out in the form of a beautiful pageant. The dances represent different phases of life and presented the title "The Quest for the Pot of Gold." The dances were: Dance of the Rainbow and the Pot of Gold, Childhood at Play, Collegiate Dance, Sword Dance, Old Age. Miss Rachel Douthett, portraying the Treasure at the End of the Rainbow, gave the solo dance. The order of things was varied quite distinctly by the presentation of a Biblical Pageant. The beautiful story of Ruth and its wonderful love plot was given in a very natural manner. The reapers, gleaners, and elders made us feel as we were really in Judea.

Of course no activity is complete without music and C.C. is noted for its musicians. Two vocal selections were given, one by Miss Mary Ruth Wham, the other a duet, by Wendell Boyer and Gertrude Hamman.

The Rev. B. E. Fleming, of the Senior Class, gave the Cedar Day Oration. His subject was "Have Gratitude and Show It."

\section{COMMITTEE IN CHARGE}

Costumes Miss Jennie Lust

Music Miss Mary Ruth Wham

Pageant Dean and Carmen Frazier Dances. Miss Irene Shannon

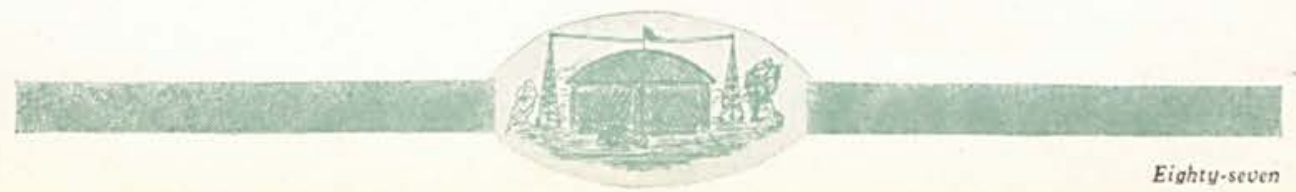




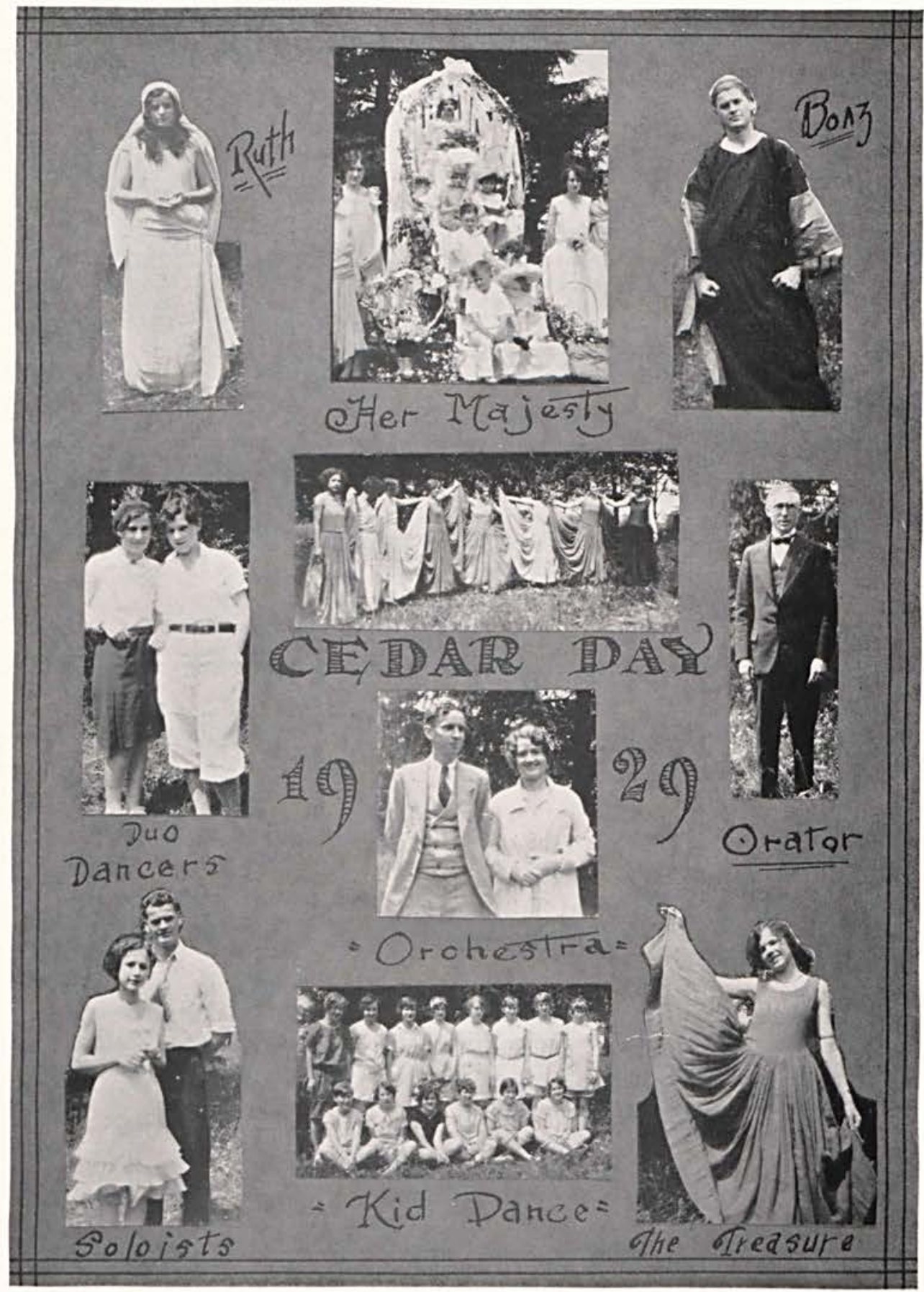




\section{Thirty=Third Annual Commencement}

$\mathrm{T}$

HE thirty-third annual commencement processional began at the Carnegie Library and ended on the beautifully decorated stage of the Cedarville Opera House.

The invocation was given by the Reverend G. LaClede Markle. The main address was delivered by the Honorable Bishop Edwin H. Hughes of the Methodist Episcopal Church.

The degree of Bachelor of Arts was conferred upon sixteen graduates of the four-year arts course. One received the degree of Bachelor of Science. Diplomas were awarded thirteen graduates of the two-year Normal Department. All the degrees were conferred by Doctor McChesney.

Five Crown pins were awarded. Two graduates received the honor of Magna Cum Laude and three Cum Laude.

The farewell address for the Seniors and the benediction were delivered by President McChesney.

\section{Baccalaureate}

COMMENCEMENT WEEK of 1929 opened Sunday evening, June the second, when the Seniors marched down the aisles of the First Presbyterian Church in their last college church service.

The invocation was given by Reverend Doctor W. P. Harriman, pastor of the First Presbyterian Church of Cedarville, after which the Scripture Lesson was offered by the Reverend T. R. Turner of Quincy. Mass. Prayer was offered by the Reverend H. C. Gunnett, pastor of the Methodist Episcopal Church of Cedarville.

Special music was furnished by the Girls' Glee Club of the College. They were assisted by Mrs. Walter Corry and directed by Miss Berkley, Professor of Music at the college.

The baccalaureate sermon was delivered by Doctor McChesney in his usual pleasing and convincing manner.

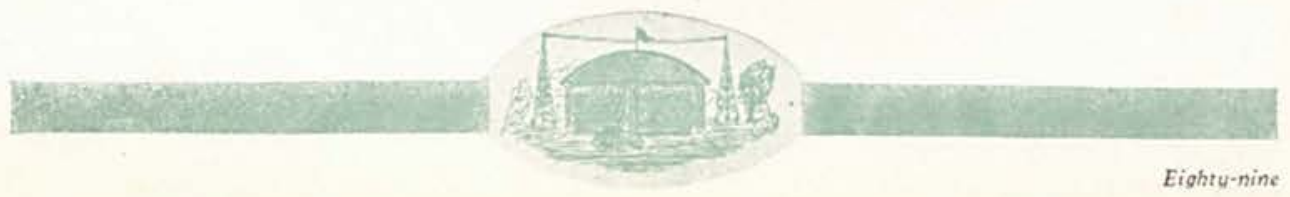




\section{Mother and Daughter Banquet}

$\mathrm{T}$ HE Mother and Daughter banquet held in the Alford Memorial Gymnasium. May 10, was proclaimed a decided success by all in attendance.

The banquet is not an old custom, but was initiated by the girls of the Y. W. C. A. as an Etiquette Project two years ago. After the success of the first it was the unanimous wish that the banquet be made an annual affair.

\begin{tabular}{lcc} 
& \multicolumn{1}{c}{ THE MENU } & \\
Green Beans & $\begin{array}{c}\text { Fruit Cocktail } \\
\text { Pressed Meat }\end{array}$ & Pickles \\
Rolls & $\begin{array}{c}\text { Stuffed Potatoes } \\
\text { Strawberry Jam }\end{array}$ & Butter \\
Devil's Food Cake & Perfection Salad & Cream
\end{tabular}

Coffee

Following the dinner hour Miss Josephine Auld, president of the Y. W. assumed the duties of toastmistress. The Welcome to the Mothers was given by Miss Grace Wigal and Mrs. R. M. Borst voiced the response of the mothers. Miss Mary McKay sang that beautiful little song, "Little Mother." This was followed by a very memorable speech. "What Mothers Means to Daughter" by Miss Martha Dean, our faculty advisor. Then Miss Carmen Frazier read the delightful little poem, "The Common Mother." This was followed by the solo, "Mother Machree" by Miss Mary Ruth Wham (sung as only Mary Ruth can). Then came the feature of the evening, the address by Mrs. E. D. McKune, of Rushville, Indiana.

$$
\text { C. F. }
$$

\section{President's Reception}

The invitation to "Dr. Mac's Reception" was greeted with wild delight from every student and member of the faculty. We all love to go to our president's home; and on the eve of the "Big Occasion" we were all there, each resplendent in manner, dress, and state of mind.

Dr. and Mrs. McChesney (whom we love to call Dr. and Mrs. Mac) received the guests and extended a hearty welcome to all.

A very delicious lunch consisting of veal salad, olives and wafers, ice cream, lady fingers, and coffee was served. Following the lunch hour was a short program. There was first a selection played by Miss Dorothy Wolff on the banjo-uke. This was followed by a piano solo by Miss Lenora Skinnell. Last came an impromptu reading by Miss Carmen Frazier.

$$
\text { C. F. }
$$

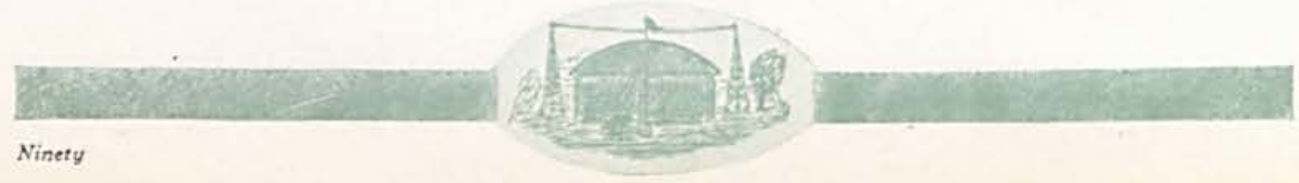




\section{Junior:Senior Banquet}

$\mathrm{T}$

HE Junior-Senior banquet in honor of the class of '29 was held at the Engineers' Club in Dayton on Thursday, May ninth, nineteen hundred and twenty-nine.

Long tables were arranged in the form of a horseshoe to accommodate the guests. The Senior colors, peach and green, were used in the table decorations. The places were designated by quaint cards upon which the names of the guests were written. The favors were small chocolate flower pots with a miniature artificial rose.

$\begin{array}{ccc} & \text { THE MENU } & \text { Fruit Cocktail } \\ \text { Celery } & \text { Olives } \\ \text { Breaded Veal Chops } & \\ \text { French Fried Potatoes } \\ \text { Tomato Salad } \\ \begin{array}{ccc}\text { Butter } & \text { Hot Rolls Cow Peas } \\ \text { Strawberry Shortcake with Cream }\end{array}\end{array}$

The music during the dinner hour was furnished by the Misses Arcelia Phillips and Florence Gaynor.

The evening's program represented "The Gates of Life." $\mathrm{Mr}$. Dallas Marshall very capably acted the role of toastmaster. The Welcome, representing "The Gates Flung Wide," was given by Mr. Paul Tanner, president of the Junior Class. Miss Margaret Chandler, president of the Senior Class, fittingly gave the Response of "We Enter." Then Professor Virginia Parry spoke on "The Challenge of Play." Miss Lillias Ford "The Challenge of Friends." Doctor W. R. McChesney very ably spoke on "The Challenge of Work." Mr. Robert Jacobs gave the Farewell, "We Go."

Three beautiful musical selections were given during the program. Two vocal selections, one by Miss Mary Ruth Wham, the other by Mr. George Gordon. Miss Lydia Berkley. Professor of Music of the College, entertained with a piano solo. J. M.

\section{Faculty Reception}

UNE the third-lovely evening - handsome dress - high spirits - splendid program-excellent refreshments-.

The Faculty Reception this year was held in the Alford Memorial Gymnasium. A goodly crowd assembled and among the guests were several alumni and former students. All were warmly received by the Faculty and the Seniors.

Doctor McChesney in his usual pleasing manner announced each number of the program. The guests were agreeably surprised and pleased when it was announced that Chaplain La Clede Markle, an alumnus, would sing. Miss Helen Iliffe, an alumna, also rendered a vocal selection. Miss Carmen Frazier in a unique reading detailed the ridiculous situation of "Keeping a Seat at the Theatre." served.

Following the program refreshments consisting of punch and cakes were

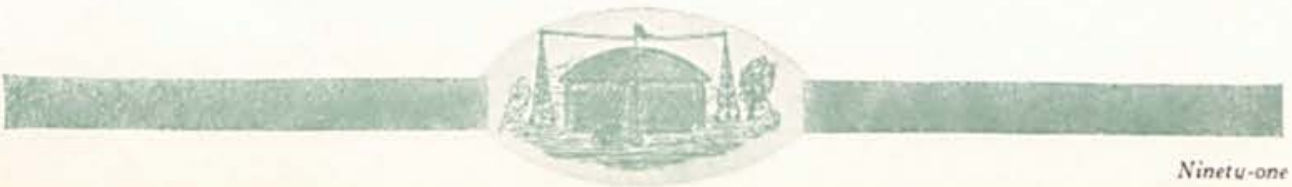




\section{Committal Service}

7 HIS year after the membership campaign of the Y. W. C. A., the Committal Service was held as is the usual custom. It was held in the College Chapel in October and was unusually beautiful and impressive.

The girls came in two abreast singing. "O Master, Let Me Walk With Thee." The upper class girls came first, followed by the new members and then the Y.W. cabinet members who were dressed in white.

The President, Frances McChesney, was in charge of the service wherein the new members took the National Pledge and the old members were rededicated.

Then the lights were lowered and the leader lighting her tall candle, came forward, lighted the candle of the vice-president. The vice-president then lighted the candle of the girl nearest her. This act was repeated until every girl held a tiny light. Then rising, the group sang the beautiful Y. W. hymn, "Follow the Gleam." The service was closed with the Indian Benediction.

In the social hour which followed tea and cakes were served. Those in attendance were the Women's Advisory Board, Wives of Faculty Members, Lady Members of the Faculty, and the girls of the Y. W. C. A.

\section{Hallowe'en Party}

T WAS dark and still outside. It was dim-but quite hilarious inside. What a strange assembly. Witches, clowns, and spooks. There were dudes and flappers, rowdy young farmers, stage stars, little girls without their mamas, grandmothers without their grandchildren, husbands without their wives. Oh, it was a motley group. Here and there was a perfectly normal everyday citizen, but he looked and acted decidedly out of place.

All things must come to an end sometime and this party was no exception. After an authoritative word, masks were removed and mischievious and familiar faces peered out from peculiar surroundings. Mercy, me, that whimpering old grand-mama was none other than Marion Hostetler; and the dumpy little lady, who looked as if she wanted her mama, was Herb Main. It was hard to imagine, but nevertheless it was so.

The group, a civilized one once more, entertained itself highly: participating in contest, singing, and playing old time and modern games. Then came the best part of the evening, the eats, which consisted of baked ham sandwiches, potato salad, pumpkin pie, pickles and coffee.

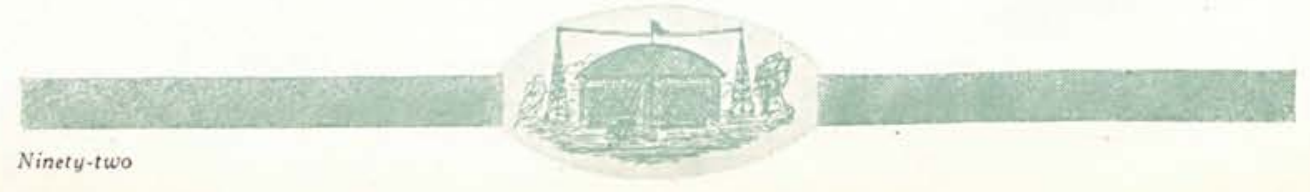




\section{The Mock Wedding}

W

HO is there among us who does not remember or has not heard of the memorable Mock Wedding of '29? It is a tale we will love to tell our grand-children and our grand-nephews and nieces who will listen in awe and horror to the recital of such savage deeds, or perchance merely in respect for our eccentricities.

It was a grand occasion. The wedding was to be held in the fine old presidential mansion on Xenia Avenue. There was much hurry and scurry, and anticipation, and great secrecy on the part of the girls and watchful waiting on the part of the boys.

The guests started to arrive early, and each charming lady was escorted by an equally charming gentleman (A lamb in wolf's clothing). It was upon the arrival of Mr. and Mrs. I-Don't-Mean-Maybe, parents of the groom, and their friends, Mr. and Mrs. Paderewski, that the unforseen happened. For simultaneously with their appearance was that of a strange car at the curb, and when the door was opened to receive the distinguished guests two menacing figures sprang from the car and fairly forced an entrance. Consternation was upon every face-except two. These expressed something of wonder and secret triumph. The owners were openly congratulating themselves that they were treading where man had ne'er trod before. The refined guests, loath to disturb their really fine appearances, wisely avoided an issue and continued with the preparations for the ceremony.

The wedding party had assembled in an upper room preparatory to the processional down the long winding stairway. The guests below were awaiting anxiously the sweet notes, "Oh. Promise Me" when, from above came a rush of many feet and down the open stairway came the boys. There were big boys and little boys: there were homely ones and handsome ones: there were good ones and bad ones-all united in a common cause. They were everywhere. They brushed the ladies aside as so many obstacles in their path; they gazed with ill-concealed contempt upon the would-be gentlemen. Once-adored ladies shrank fearfully from had-been lovers, and if any attempted to remonstrate with the intruders she was brutally bidden. "Shut up!" or "Pipe down!"

In the midst of the hubbub the leaders of the two factions met and came to an agreement - that the boys be permitted to witness the wedding, but that they must not disurb it in any way. Thus some semblance of order was restored and the ceremony commenced. First the beautiful solos. "Oh, Promise Me," "At Dawning" and "I Love You Truly"; then the measured beat of the wedding march-and down the stairway came the bride with her attendants. Ah! Methinks that ne'er was a bride more lovely. It was a tense moment. At the foot of the stairway stood her big, masterful lover; at the altar stood her quaking would-be groom. Would the giant snatch her up and leap through the door? She met his look calmly and fearlessly, and-then she was safely past.

The ceremony proceeded uninterrupted, though there were murmurings and

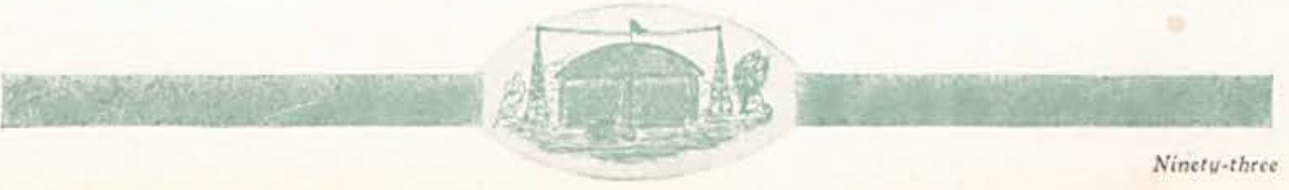


restlessness among the boys. At the close of the ceremony they pressed forward loudly claiming the privilege of kissing the bride, but she deftly evaded them and escaped with her party into the dining-room. Foiled in this and tantalized by delicious odors from the direction of the dining-room, they attempted to storm that portion of the house. Then it was that the ladies assered themselves. Whereas at first they had been dazed and timid, now they stood up and fought like men. Here was one dealing out hearty slaps to any willing or unwilling and ready to receive: here, one was burying dainty fingers in short, greasy locks: here, one resplendent in gentleman's attire, reposed serently upon her back, held firmly there by the knee of a triumphant rioter. Some were crying helplessly: some were giggling hysterically: some were shrieking madly. "The brutes! the brutes!" And everyone was having a gay time until-a lady's delicate chin came in violent contact with a brutal fist, and the owner of the chin sank peacefully into oblivion. It was the end of the fray. The boys scattered; a doctor was summoned; the girl revived;- - and lunch was served.

It was a delicious lunch: chicken patties, potatoes, pickles, perfection salad, wafers, ice cream, cake, and coffee.

Those participating in the wedding ceremony were: the bride. Miss Irene Shannon; the groom. Mr. Nedra Wilson: the maid of honor, Miss Margaret Chandler; the best man, Mr. Lucile Tanner: bride's maids, Miss Zora Smith. Miss Hilma Raisanen, and Miss Josephine Auld: bride's parents, Mr. Evelyn Kennedy and Miss Ruth Marshall; groom's parents, Mr. Isabel Webster and Miss Verla Bishop; flower girls, Misses Badstuber and Yaple; ringbearer, Master Jean Morton; ushers, Messrs. Martin and McChesney: soloists, Misses Mary McKay, Gertrude Hamman, and Mary Ruth Wham. The wedding march was played by Miss Alberta Snyder. The happy couple were duly joined in matrimony by the Reverend Frances Anderson.

$$
\text { C. F. }
$$

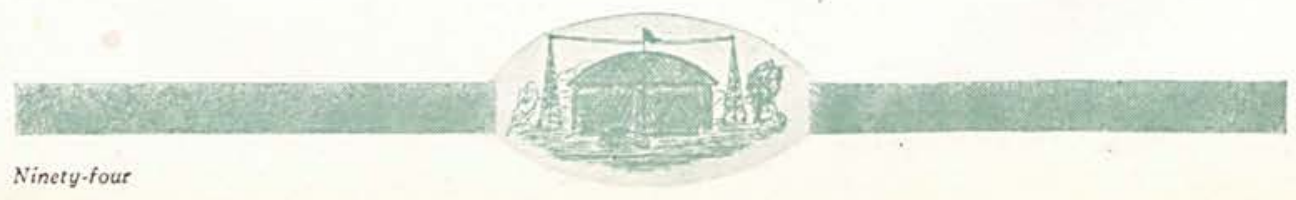




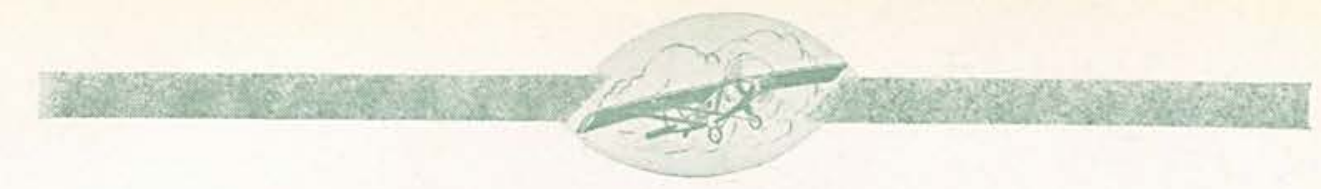

\section{Y. W. C. A. Welcome Tea}

It has long been the custom at Cedarville for the members of the Y. W. to give a tea in honor of the new girls. This year the tea was held, September 12, in the College Club Waiting-Room. It was a rainy afternoon and was enough to dampen the most blithesome spirit; but the waiting-room was warm and cozy, and a goodly number was in attendance. The Big Sisters took their Little Sisters "under wing" and made them feel happily at home. A delightful program of music was enjoyed: A piano solo, Miss Mary Ruth Wham: a cello solo, Miss Bernese Elias; a vocal solo, Miss Helen Iliffe, after which tea and little cakes were served the guests.

C. F.

\section{Y. M. and Y. W. Get:Together}

The "Get-Together" was slightly different from that last year. Then the social hour had been given over to Freshman scalp-taking; while this year every man was at peace with his neighbor. True, the upper classman eyed narrowly the cocky freshman as he strutted jauntily hither and thither; but he had given his word and he reckoned, "dash-it-all," he would have to keep it.

Yes, the Y. M. and the Y. W. conducted the "Get-Together" as Y. M.'s and Y. W.'s should. The new students were made to feel at home and the old gym rang with hearty laughter and rousing song. The new students were initiated into Cedarville social life to the tune and step of "Captain Jenks," "Pig in the Parlor," "Miller Boy," and refreshed with weiner sandwiches, hot cocoa, and cakes.

$$
\text { C. F. }
$$

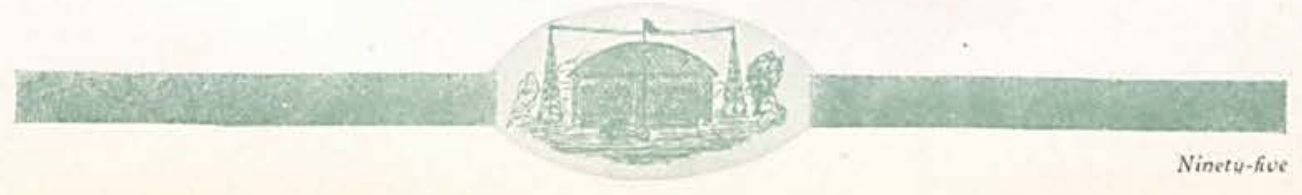




\section{Junior Class Play '29}

\section{"BILLY"}

A hilarious comedy in three acts by George Cameron. We will never forget the teethless Pickering and Wham. Seasick Sam Eustace and the winsome Beatrice. The scenery for this play presented something entirely different with its ocean liner background.

\section{CAST OF CHARACTERS}

Billy Hargrave, a football hero Harry Pickering

Alice Hargrave, his sister Dortha Fanning

John Hargrave, his father James Stormont

Mrs. Hargrave, his mother Lillias Ford

Mrs. Sloane Mary Ruth Wham

Sam Eustace Dallas Marshall

Beatrice Sloane, Mrs. Sloane's daughter Jean Morton

Captain

Robert Thompson

Doctor Paul Tanner

Boatswain Frank Graham

Sailor Blair Brasel

Steward Charles Kyle

Stewardess Hilma Raisanen

\section{Junior Class Play'30}

\section{"KEMPY"}

The class of ' 31 continued to uphold the prestige of Cedarville College actors and actresses by very cleverly presenting this play. It was hard for us to figure out how everything was going to happen so they could all live happily ever after. But after much planning by $A 1$ and Carmen and some hasty decisions by Sarah, the entire plot was laid clearly before our eyes.

\section{CAST OF CHARACTERS}

Ruth Bence

Dad Bence

"Ma"

Jane Wade

Katherine Bence

Ben Wade

"Kempy" James

"Duke" Merril
Carmen Frazier

Robert Collins Christine Rife Helen Powers Sarah Rumbaugh Vernon Hickman Alfred Townsley Wendell Boyer 


\section{Cedarville College Diary}

SEPTEMBER

9-Rain. One Freshman arrives.

10-Clear. The other three Freshmen arrive.

11 - Commencing day. Mr. Clifton chapels. Schedules-books-tuish"I swear I will not stack the chapel" often. Yellowstoners all intown.

12 - Students dribble in. Y. M. \& W. you know at nite.

14 - First week-end. Are they all gonna be like this?

16 - Students watch the birdie. Seniors watch chicken at Marshall's.

17 - Crowd divides. U. P. Reception, Otto Gray's Wild West, and Avalon Park. Otto corners the most.

$18-2$ A. M. Avaloners return.

19-Choppy arrives behind schedule. Real schedule choppied up as yet.

20 - Yell sheets passed. Teamsters in transit to Transylvania.

21 -We-6. They-64 more.

23-Ticker tapester at Morton's. Soffeed at Auld's.

25 - Yearling girls rattle rattles.

26-The Earl of Egypt in chapel. Rife voted "Freshest" Pres.

Girls' Tea for two or three at Methodist. Chicken at Presby. Be a Presby.

27 - Fresh swab steps. "How green I am." Photos here all ready already. Presby. organ recites.

28-Cincinnati is three touchdowns better and $\$ 300$ worse off.

30-Borst explains in chapel. Cedar Inn party, anniversary of Ballards birth.

\section{OCTOBER}

1-Philos. will try it one more year.

2 -Uppers enjoy Fresh. feed at Swaby's. Turner-Hostetler all damp. Roseberrys found in Nebraska.

3-Pepster meeting, snake dance, cones gratis at the mayor's. Mr. Strain appears on the grounds.

5-Wilmington, O., Cedarville, O. Practically as good as we.

7 - Nuther pep meet. Seniors treat. Toby, Modic barefoot it in from O. M. Camp.

8 - Some eat at Rumbaugh's.

9-Sophs throw mean line at Flax. Fresh wade home. Office rug warm.

10-M. E. Church entertains. Experience meeting at Morton's. Only nice clean experiences allowed.

11 - Brass band born.

12-Northern 26-6. Too far north for us. 

9-Sweaters arrive. All ready to be worn out.

10-Mrs. Schick's children (no, no, not that) entertain in chapel.

11 - Lecture on how to study and go to games too. Speaking of useless lectures.

13-You of see beats see see. Little Bruiser gets a big hand.

14 - St. X. also has a good ball team.

16-Filos throw a party. Food, presents, and such nonsense.

17-Still another Y. W. feed at Marshall's. Otta call it the Young Women's Chicken Association.

18 - Juniors played "Kempy" three acts and then gave it up.

19-Intermission. "They scattered for the Christmas spree,

By rail, and bus, and Model 'T.'.'

20-Important date. Mayor's nickel record machine installed.

21 -Record machine still in. Stalled. Installments?

23-The Walter Boyer's get the best Christmas gift.

25-Stocking up day. The world loveth a careful giver.

\section{JANUARY}

1 - Students sign pledges.

2 - Students resign their pledges.

4-Basketball season a success. Dayton beaten 25-24. HA, Ha, ha.

6 - Students amble in. Transylvania donates us one.

8 -Findlay finished. Team gets bettah and bettah.

9 -Usburn gets chicken-pox.

10 - Gals sing in the bath tub.

13-Dr. Mac travels. Skinnell out with measles. Glee Club photoed.

14-Ohio Staters win. Well, they otta.

15-History class feed that will go down in history.

16-Camel's birthday. Egg cooked in chapel. Church bells ring. Hot dogs and candy for sale. To create thirst.

20-Tobias' birthday. One guess.

21 -'30 and ' 31 eat at Nagley's Home for Girls.

22 - Eloise Farquhar hurt on sled ride.

23-Wilmington wins. Sounds familiar.

24-Urbana loses to varsity. Northernettes lose to Rojer Stormont.

26 - Leaves begin to turn.

27-Exams. "Ten out of twelve, no questions, and keep your eyes on your own paper."

28 - Profs. grading the funnies.

30 - Time out. Four days between first and second acts.

31-Bliss and Spfld. B. C. demolished.

\section{FEBRUARY}

1 - Suprise. Antioch wins.

2-Iddings out of Doc's, sees shadow. Six more weeks of winter.

3-A day at cards. Registration and admission.

4-Classes, no chapel, lyceum, 'Ansome 'Oibert's boithday.

5-U. D. wins. They didn't the first time tho. 



\section{Jokes}

Rife: I've learned lots of new tricks. I can imitate any bird that you name.

Susie: Suppose that you imitate the "homing pigeon."

A professor tells us that petting involves emotional excitement. Do you suppose that he would kid us?

Clerk in Five and Ten: You can have anything in here for a dime.

Brenton. I'll take that little blonde behind the candy counter.

Sarah Margaret: Were you mad when Hinton kissed you?

Lenore: Say it just burned me up.

Prof. Hostetler: If a child is born inside the three mile limit, it belongs to the United States.

Bob Bratton: Gee, I thought that it belonged to its mother.

Jack Osborne: Do you know that Swaby thinks that Marshall Fields is a play-ground?

Regina: Well, what does Red use those fields for?

Herbie: Why did Grant put on his old clothes?

Lawliss: He told me that he had a blind date.

Father: Why were you suspended from college?

Foster: Constant interruptions prevented my studying.

Father: Interruptions? In what forms?

Foster: (reminiscently) Ah, those forms!

Powers (at riding academy): I want a saddle horse.

Riding Master: What kind of a saddle do you want?

Powers: What is the difference?

Riding Master: English saddles are perfectly plain and Mexican saddles have a horn.

Powers: Give me the one with a horn. I am not used to the traffic. 


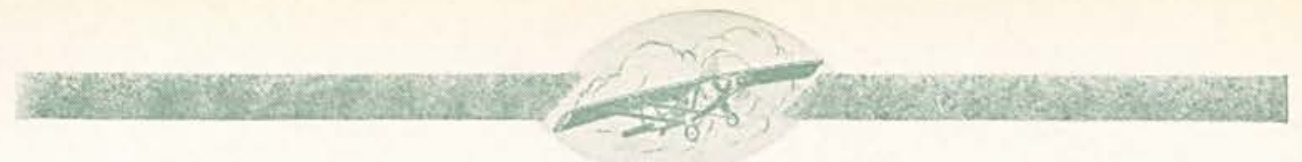

\section{"Please Notice"}

T $T$ is utterly impossible to publish a decent annual at C.C. without help from the outside. This help comes through the gratitude of generous merchants and business men. It is not possible to express in writing our appreciation for their aid.

Readers, will you please, if you ever have the chance, tell the firms or individuals listed below that you saw their ad in "The Cedrus" and you were glad to see that they helped Cedarville College. This one little favor from you will bring untold results. It will make future advertising far easier and will create a friendship for the college that cannot be broken. We thank you in advance for this.

\section{OUR ADVERTISERS}

\section{Cedarville}

Cedarville College

Hagar Straw Board \& Paper Co.

Richards Drug Store

Cedarville Herald

C. E. Masters

W. W. Troute

C. H. Crouse

Wolford's Garage

I. C. Davis

Home Clothing Co.

Brown's Drugs

A. E. Huey

The Exchange Bank

Robert Bird \& Sons Co.

W. L. Clemans

INDIANAPOLIS

Stafford Engraving Co.
XENIA

McCurran Brothers, Contractors Hy-Art Shop

Xenia Auto Necessity

C. A. Weaver Co.

Jobe Bros.

Xenia Candy Kitchen

The Criterion

Wagner Jewelry Co.

Geyer's Book Store

Valet Press Shop

Osterly Millinery Co.

Wood's Barber Shop

Eichman Electric Shop

Adair Furniture Co.

Bijou Theater

Greene County Auto Club

Pidgeon Battery Co.

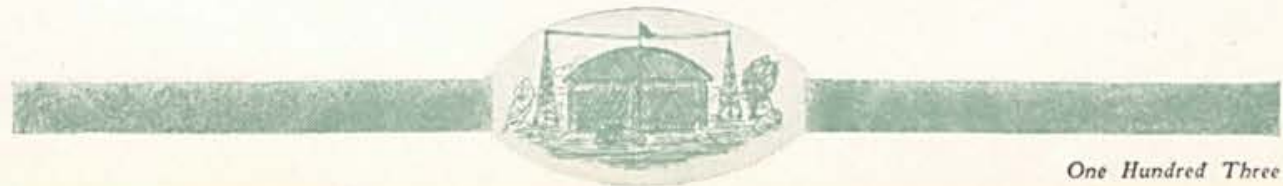




\section{CEDARVILLE COLLEGE}

\section{Is Forging to the Front}

\section{Get a College Training}

The times demand it.

The results justify it.

\section{Come to Cedarville College}

The location is healthful and beautiful.

The opportunities are fine and inspiring.

The courses are complete and modern.

The influences are safe and helpful.

The expenses are lower than at many other places.

The students are possessed of high ideals and practice them.

The faculty is experienced and thoroughly trained.

\section{Football, Basketball, Baseball and Tennis \\ Physical Education and Gymnastics}

The College is recognized by the Department of Public Education of the State of Ohio, and by the leading universities.

In Cedarville College you can get preparation for any pursuit in life.

A large Freshman class is to enroll in September. The prospects for a record-breaking attendance are splendid.

Thirty-seventh year opens September 10, 1930.

For catalog and further particulars, address

W. R. McCHESNEY, Ph. D., D. D., President

Cedarville, Ohio 
DRY CLEANING

PRESSING

"We Care for Those Who Care"

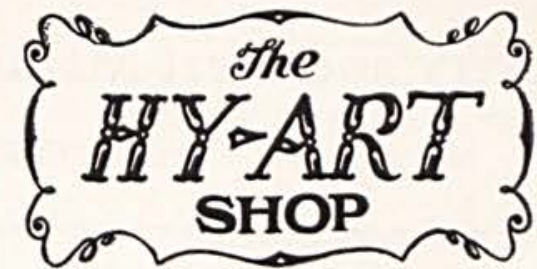

TAILORING

STEELE BLDG., XENIA, OHIO

Iddings: You kiss just like Greta Garbo.

Burnham: What, have you been two timing me?

\section{CEDARVILLE LUMBER CO.}

EVERYTHING IN

Lumber, Mill Work, Building Material, Fence and Posts, Wool, International Farm Machinery, Trucks, Tractors and Repairs PHONE 33

Mrs. Gormley: I've changed my mind.

Prof. Angevine: Well, does it work any better?
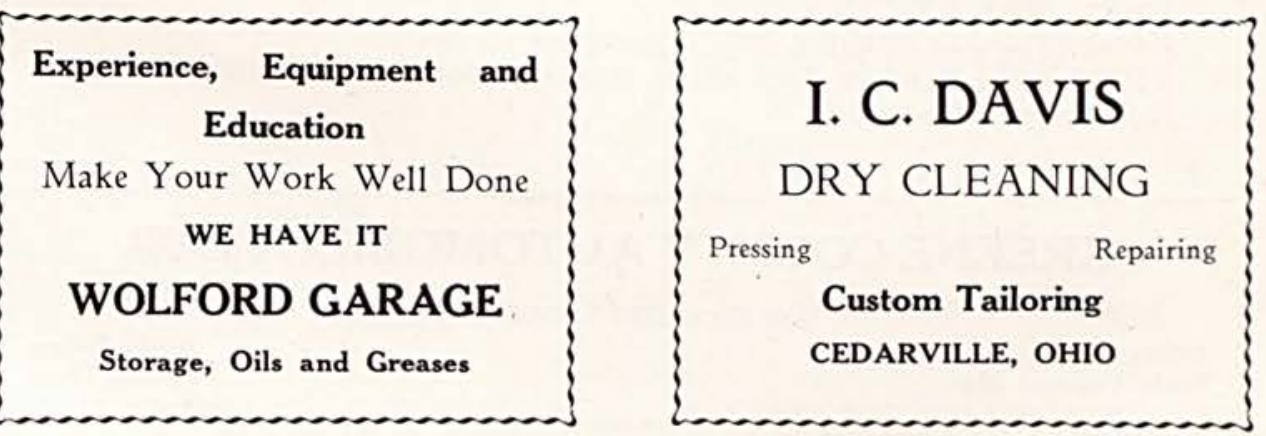


\section{E. Masters}

\section{Grocery and Meat Market}

Phone 2-44

CEDARVILLE, OHIO

Politics makes strange bedfellows, and so do football trips.

George: Where are you working now?

Bunk: Kroger's.

George: Oh, you're on the chain gang?

Ruby: I hear that you were arrested for picking up a heavy rubber band the other day.

Walter: Yes, it happened to be Kuehrman's spare tire.

\section{A. WAGNER, O. D. \\ Specializing in}

FINE WATCHES and DIAMONDS-COMFORTABLE EYEGLASSES

4 S. Detroit St.

Phone 41

Xenia, Ohio

The key to too many women's hearts are gold ones.

Elsie: Do you like dancing?

Roseberry: No.

Elsie: Why not?

Roseberry: It's nothing but hugging set to music.

Elsie: Well, what is there about that you don't like?

Roseberry. The music.

\section{GREENE COUNTY AUTOMOBILE CLUB}

"Service and Courtesy"

Dilver Beldon, Sec.

Steele Podgue, Mgr.

Steele Bldg.,
Xenia, Ohio 


\section{MEN'S AND BOYS' WEARING APPAREL}

High in Quality-Reasonable in Price

\section{HOME CLOTHING COMPANY}

Dr. Jurkat: What do you know about Greek syntax?

Maine: Did they have to pay for their fun too!

Sprinkle: They tell me that Alfred's room is spotless.

Pops: That is right, not a clean spot in it. sheet.

How to keep yourself warm at night-Reach for a blanket instead of a

\section{BROWN'S DRUGS}

\section{Bexall}

"The Best in Drug Store Service"-"The Best in Drug Store Merchandise"

Blair: What does the word "davenport" suggest to you?

Joe: A city in Iowa.

Hilma: Is your new man a good one hand driver?

Irene: Aw, he's not that slow. He takes a taxi and uses both hands.

Hartman: He sure has got submarine hands.

Wilda: How is that?

Hartman: You never know where they will turn up next.
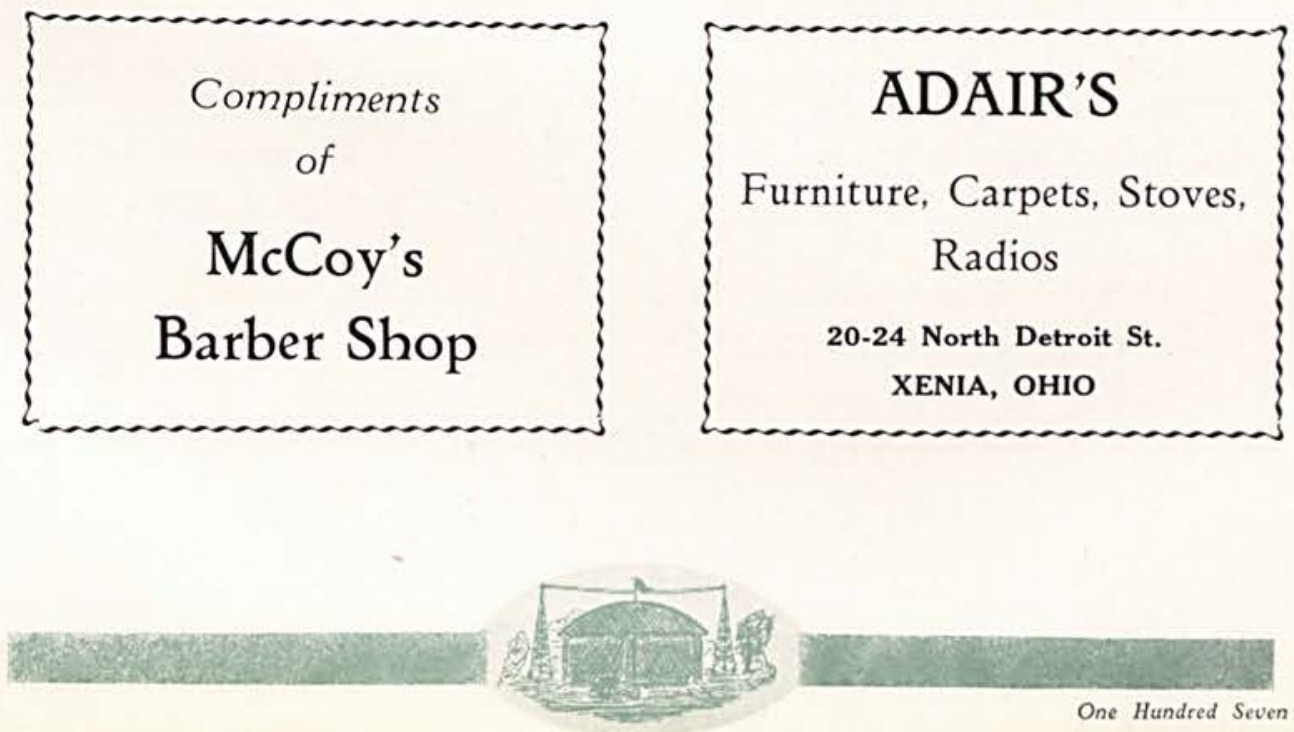


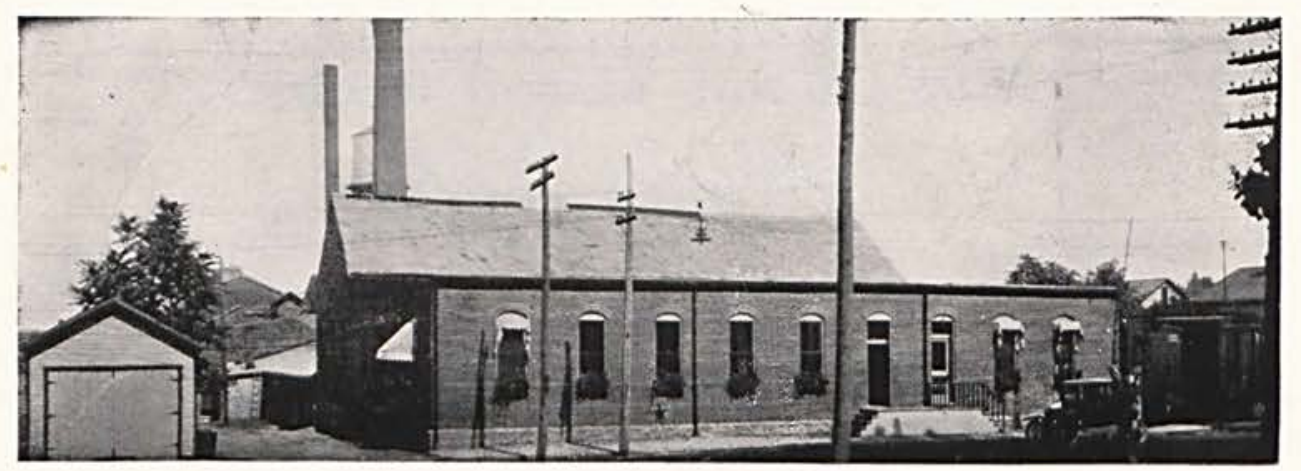

The

Hagar Srawboard

8 Paper Company

Cedarville, Ohio

Fine Straw Board

for Corrugating 


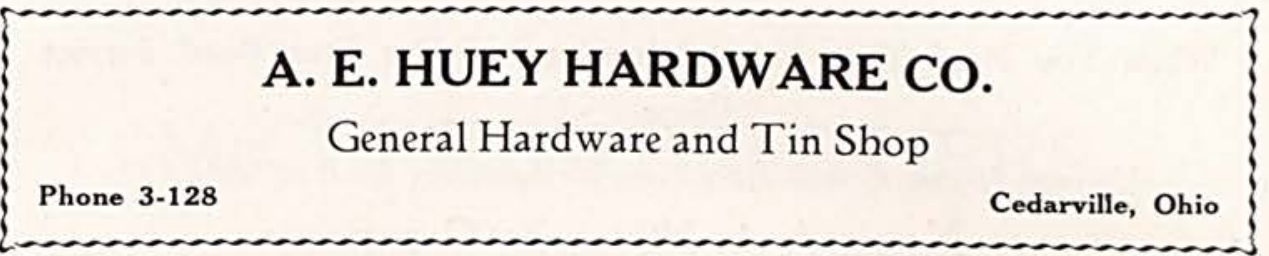

Mr. Owens: Did you find a roll under my pillow with fifty dollars in it? Porter: Yes, Suh. Thank you, Suh.

Wilma Curry: I wonder how I could live without brains?

Mrs. Shedd: That remains to be seen.

Mrs. Morton: How did you know that he was following you? Jean: He kept looking around to see if I were coming.

Prof. Wood: Mr. Townsley, you must think that this class is a barn. Al: Why?

Prof. Wood: Just one stall after another.

Central: Number, please?

Moody: Number? Woman, I put in my nickel and I want my chewing gum.
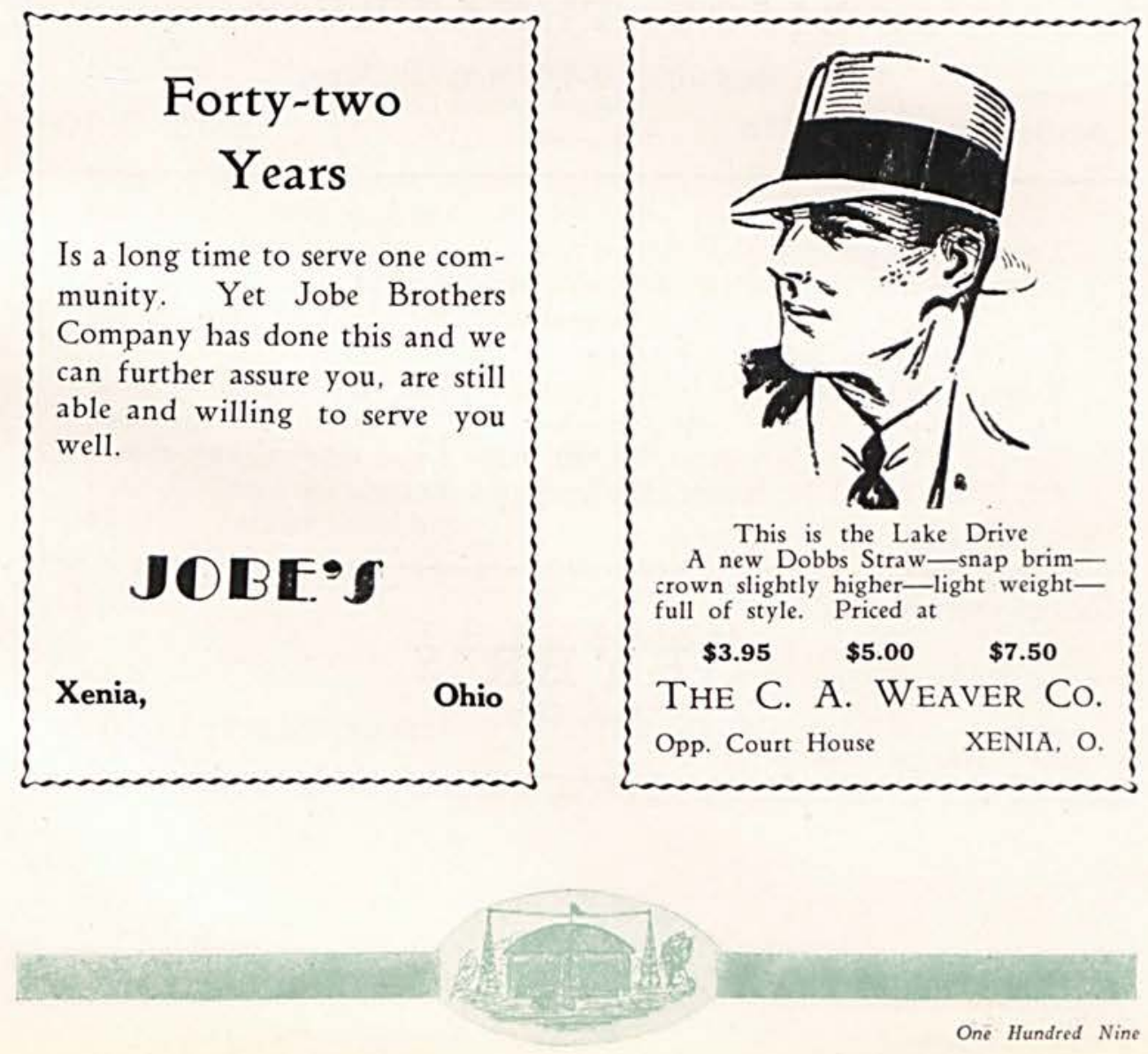
When You Need Tires Take Advantage of Our Free Road Service Phone 533

Dayton Tires, Gould Dreadnaught Batteries, Quaker State Oil

\section{Xenia Auto Necessity Company}

T. R. MCCLELLAND

R. J. McCLELLAND

31 South Detroit Street

Xenia, Ohio

Pop Lumpkin: This love business gives me a pain in the neck.

Scott: Maybe you are too athletic about it.

Many a fellow that thinks he is "hot" is only half-baked.

Marion: Well, Knick, how are you?

Knick: Wonderful, thanks.

Marion: Well, I'm glad someone thinks so.

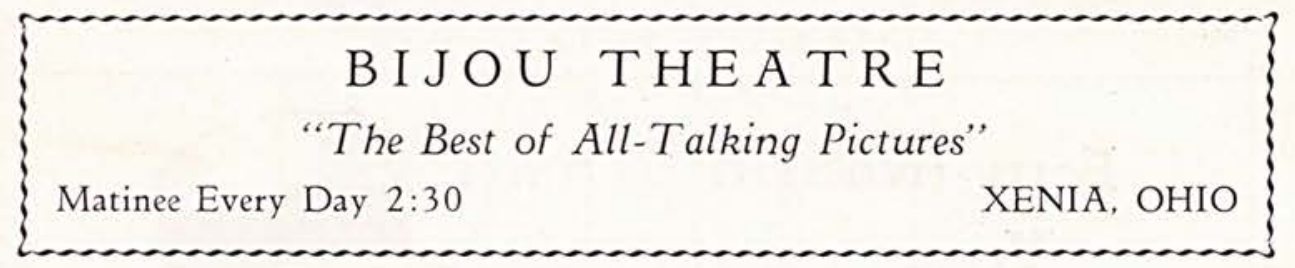

Leo: Who's going with Wilma now?

Henry: I don't know. Hinton's in the semi-finals.

Prof. Lust: Use soda in a sentence.

Kilgore: And soda bed.

Bernese: What's the matter, Eddie? Don't you love me any more?

Ed. Bull: Sure I do, Honey, but I am just resting.

GOOD THINGS TO EAT

\section{GE Y E R'S \\ Xenia, Ohio}




\title{
McCURRAN BROTHERS
}

\section{General Contractors}

\author{
PUBLIC BUILDINGS
}

FINE RESIDENCES

Out Specialty

Steele Bldg.

Xenia, Ohio

Kinnison: Garlough is a man about town.

Moody: Yes, and a fool about women.

Irons: Do you like bathing girls?

Leo: I don't know, I never bathed any.

Mantell: What is your idea of having nothing to do?

Roger: Having a date with the dean of women.

Kenney: I developed these muscles by working in the boiler factory.

Fanning: Oh, you great big wonderful man! What did you boil?

Rachel: One man dies in New York every minute.

Martin: I'd like to see him.

\section{H. E. EICHMAN}

Do It Electrically 


\title{
STANDARD ICE CREAM
}

Goodness!

\author{
How You'll Like It
}

By far the most popular Ice Cream in Cedarville for the past 15 years. There must be reasons for this continued popularity.

Special and Fancy Creams and Ices for All Occasions

\section{Richard's Drug Store}

"Populat With the Students"

MAKE YOURSELF AT HOME AT "DOC'S" 


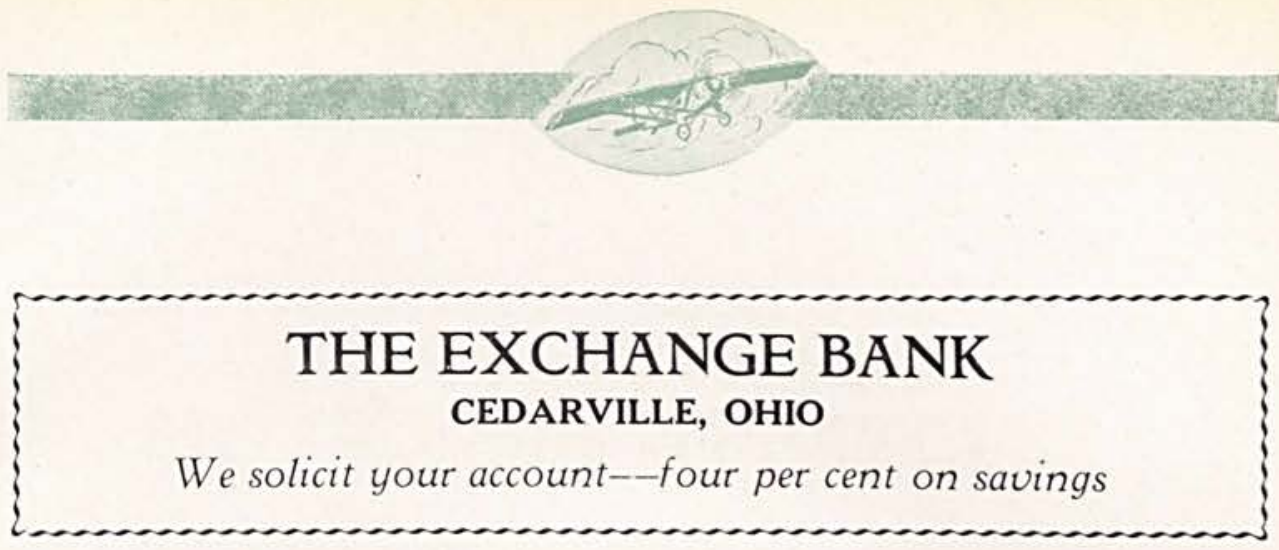
water.

Tanner: Oh, Bob, how those chocolates in the window make my mouth

Collins: Well, here is a blotter.

Bob Richards: It seems to me that you bakers are getting tight.

Willis: How is that? other day.

Bob: Dad couldn't get but four dozen sandwiches out of a loaf the

\section{W. L. CLEMANS}

Life, Health, Accident, Fire and Tornado Insurance CEDARVILLE

Rumbaugh: I want a quarter's worth of rat poison.

Doc: Do you want to take it with you?

Sarah: No, I'll send the rats in after it.

Rife: That new suit of yours is all full of ticks.

Al: It ought to be, I bought it on time.

Pickering: My dad used to be a tumbler.

Ice: Did he tumble for circuses?

Harry: No, for women.

\section{THE CEDARVILLE HERALD}

\section{Commercial - . - Catalog JOB PRINTING}

LET US GIVE YOU AN ESTIMATE ON YOUR PRINTING

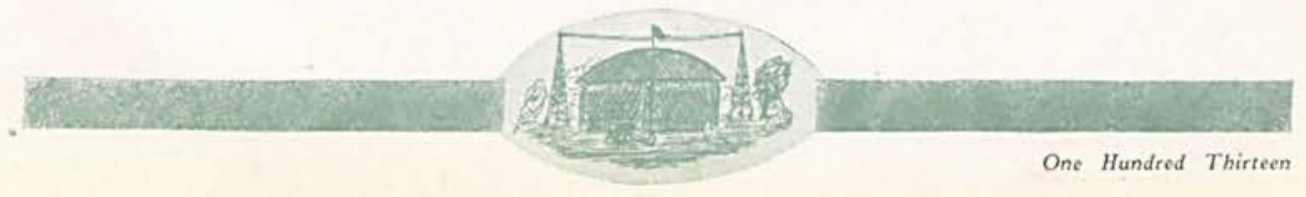




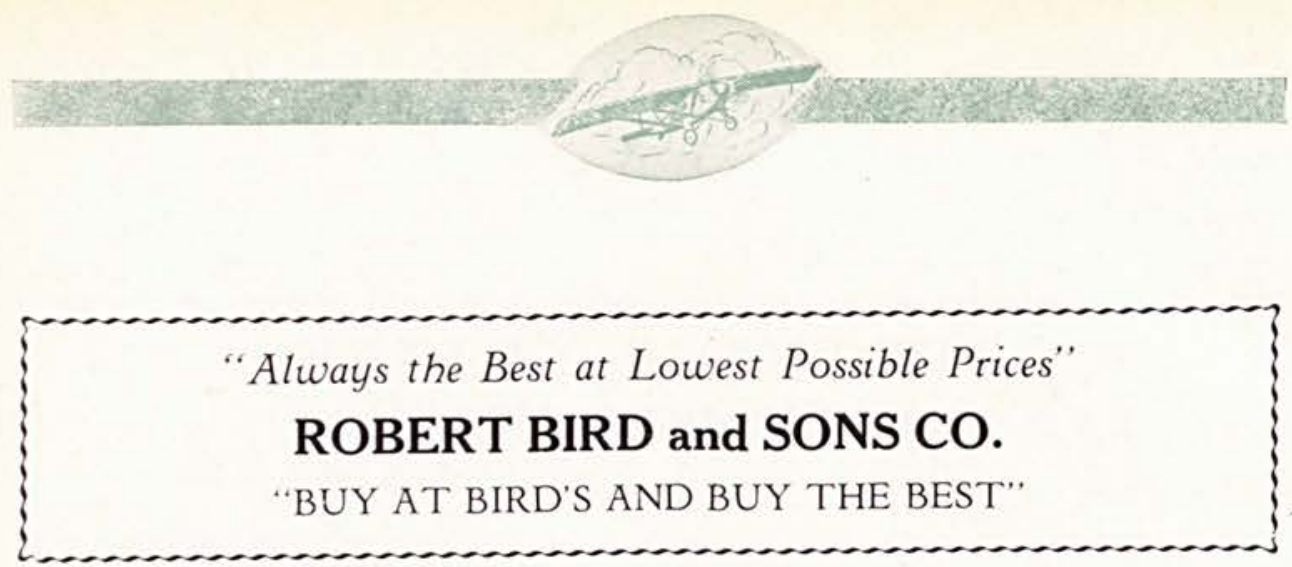

Betty: Will you marry me if I promise to cook you three meals a day?

Jasper: Yes, Honey, but is it necessary that you promise that?

Justin Hartman (in his prayer on retiring): "Dear God, watch over all good people." Then after a little thought, he added, "Maybe you had better keep an eye on 'Windy.' '"

Epitaph: Here lies an Atheist; all dressed up and no place to go.

DRY CLEANING

33 So. Detroit St.

\section{VALET PRESS SHOP}

The Most for Your Money

Bost: Professor, I can't go to class.

Prof. Davis: Why?

Bost: I don't feel well.

Prof. Davis: Where don't you feel well?

Bost: In class.

Merriman: Won't you come in?

Turner: Really, I can't. I'm not strong, you know.

\section{H. Crouse}

\section{Grocery and Meat Market}

Cedarville, 




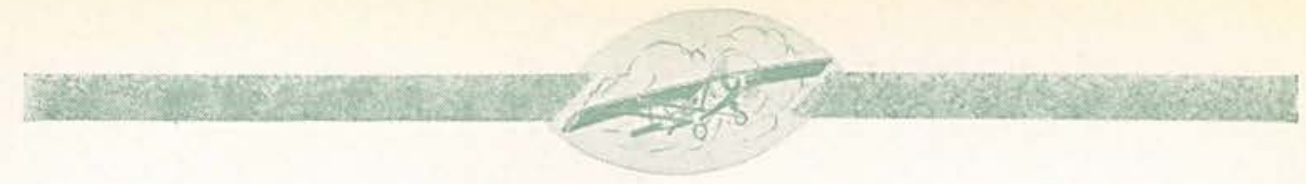
inside!

Some co-eds will not tell tales outside of school-but the ones they tell

Doctor: It's a boy, Professor.

Prof: What is?

Eddie, as he picked up a chestnut burr: Oh, Willis, come here, I've found a porcupine's egg.

Guide: We are now passing through a famous hamlet.

Mrs. Schedd: Oh, I thought that a hamlet was a little pig.

Fudge: How is your girl today?

Flatter: Oh, passion fair.

Tanner: Bob, called up the house four times before I gave him a date.

Wilma: Whom did he ask for the other three times?

Hilma: Wendell tried to kiss me tonight.

Mrs. Nagley: Did you slap him?

Hilma: Yes indeed. As soon as he got through.

Kenney: Why is a woman like a player piano?

Bunk: Because you can't play them without a roll.

A woman's mouth is usually compared to a rosebud but a rose bud is usually shut.

Rebecca: Did Eddie like your new sofa?

Garnet: He complimented me on it.

Turner: How's your new girl?

Hickman: Not so good.

Turner: You always were lucky.

Hilma: Why is Fudge walking down street between those two girls? sandwich

Mary Ruth: Ah, they are playing that they are a limburger cheese

Hinton: Don't worry, that cop can't arrest us.

Lenore: Have you got a drag at the city hall?

Hinton: No, I haven't any license plates.

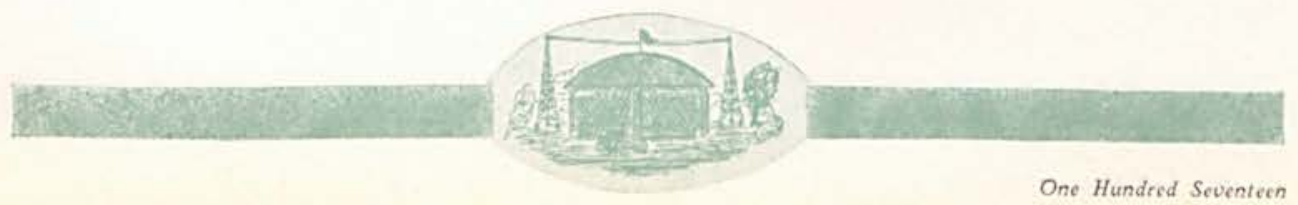


Pete: Did you take your girl home last night?

Cressy: Naw, I left her at her house.

"Just another of those thrill slayers," muttered Duffy as Dean Angevine arrived at the Ogelsbee dorm. Hello?

Doctor Mac: (Awakened by the phone from deep sleep at three A. M.)

Voice: Is this the President?

Doctor Mac: Yes.

Voice: Well, what are you doing up this late?

Mrs. Morton: Where do bad little girls go?

Jean: Most everywhere.

Kirby: I hear that Pete dabbles in oil a little.

Finney: An artist?

Kirby: No, A filling station attendant.

Sprinkle: Will your folks be surprised when you graduate?

Gordon: No, they have been expecting it for years.

Jurkat: Why do you always scratch yourself?

Half-pint: 'Cause I'm the only one who knows where I itch.

Steele: What do you call a person from Indiana?

Maine: Who, sir?

Steele: Correct.

Neighbor: Did your daughter Bernice pass the exams at college? was born.

Mrs. Bryant: No, they asked her about things that occurred before she

Fanning: Who's under the bed?

Voice: Nobody but us shoes.

Fanning: Aw, heck.

"Dear Lord," prayed Lucille Tanner, "I don't ask anything for myselfjust give mother a son-in-law."

Borst: I was very surprised to hear that you have a young son.

Walter: Oh, yes. To heir is human you know.

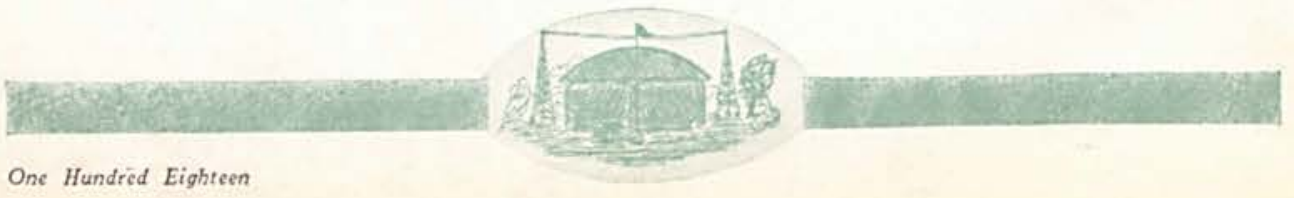



Wearitelen

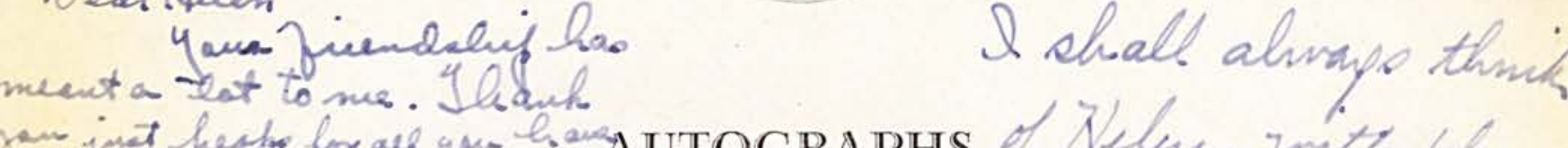

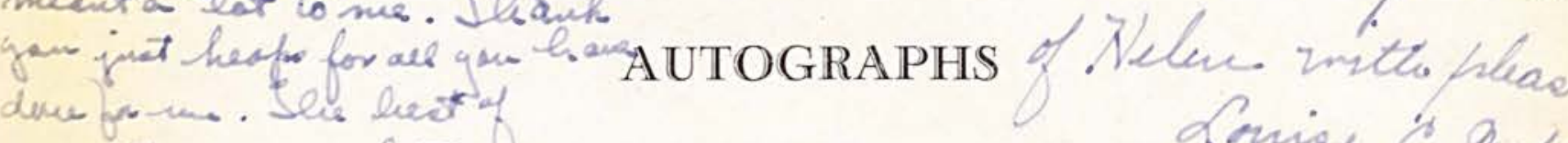

weresto y an in culsatend o ber Anise is Payl.

le. De alwerg remember.

Xon and lowe new.

Wa naran I. ioff.

Drarctsर्शि-

Scaistos yous han

enels gaver mzant on

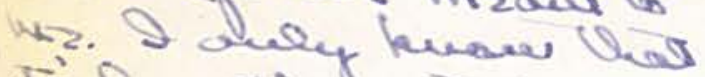

Ix frem the $x$ res 281

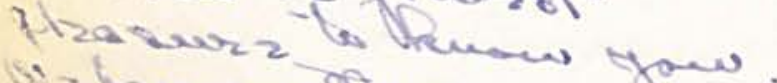

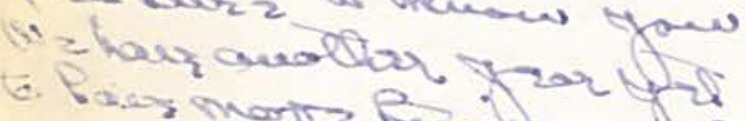

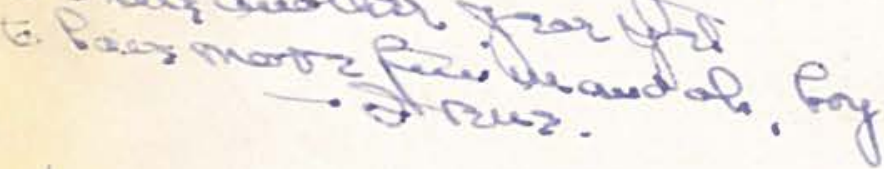

enember tre

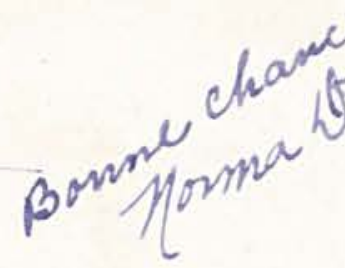

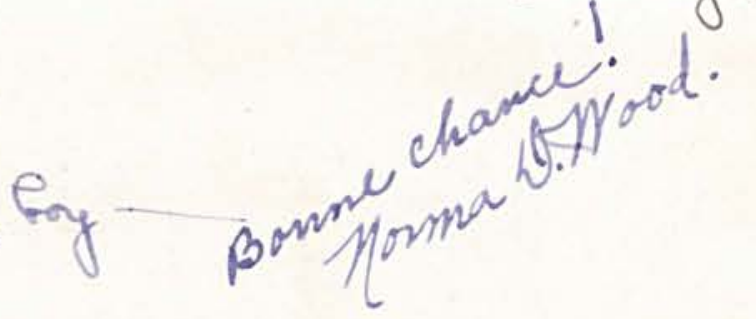

Dear Itelen joly jimgt I had with the leoeds to forrest Parkawe. Atqued at wit "Hause" and" gousped ". Hee to

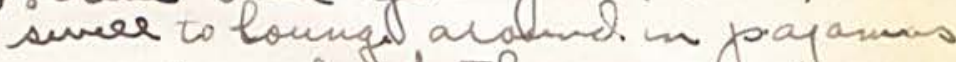
o grasif abant thase fac dan't henow. "ya "knand 

MEMORIES 



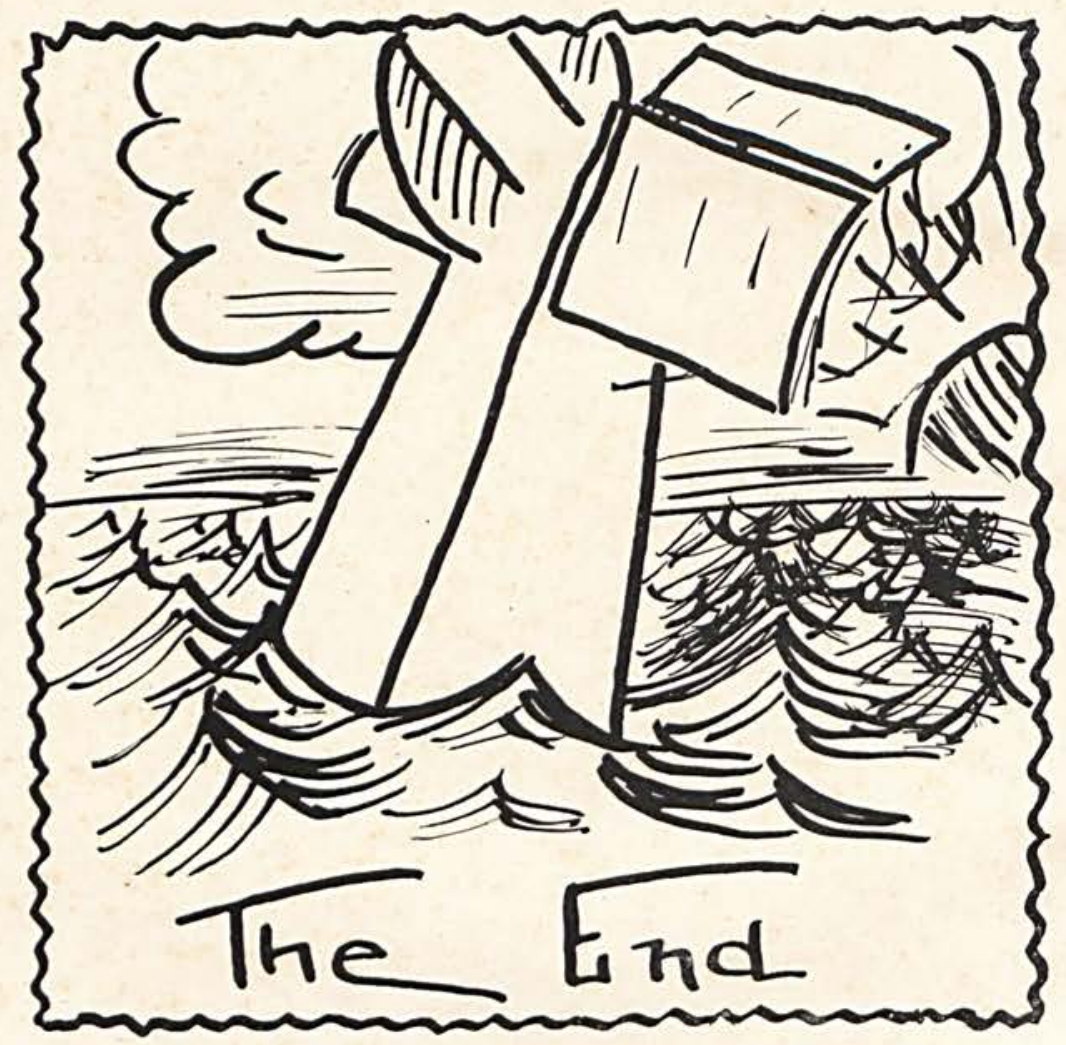


$\therefore$ 


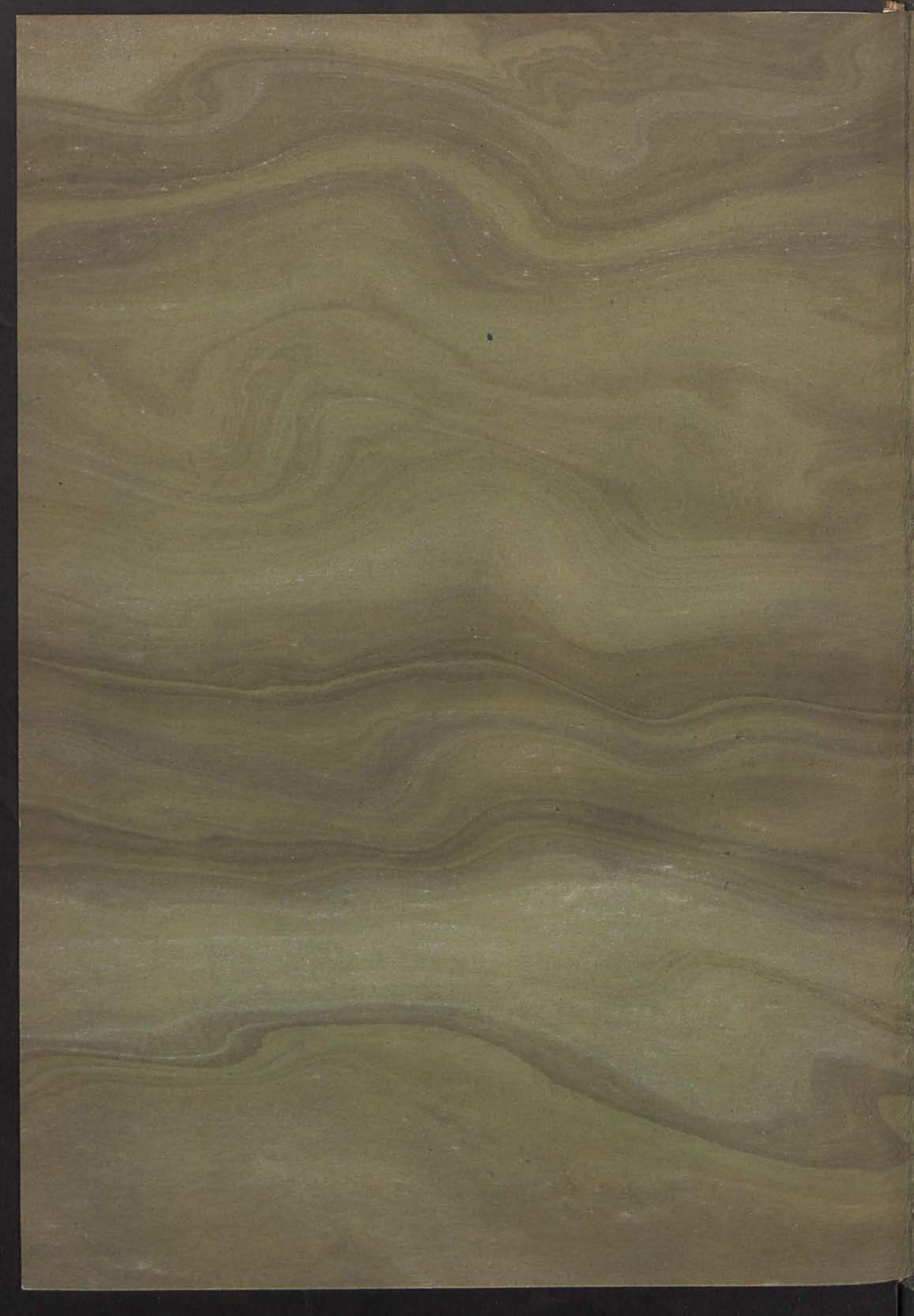


कर्षे 
